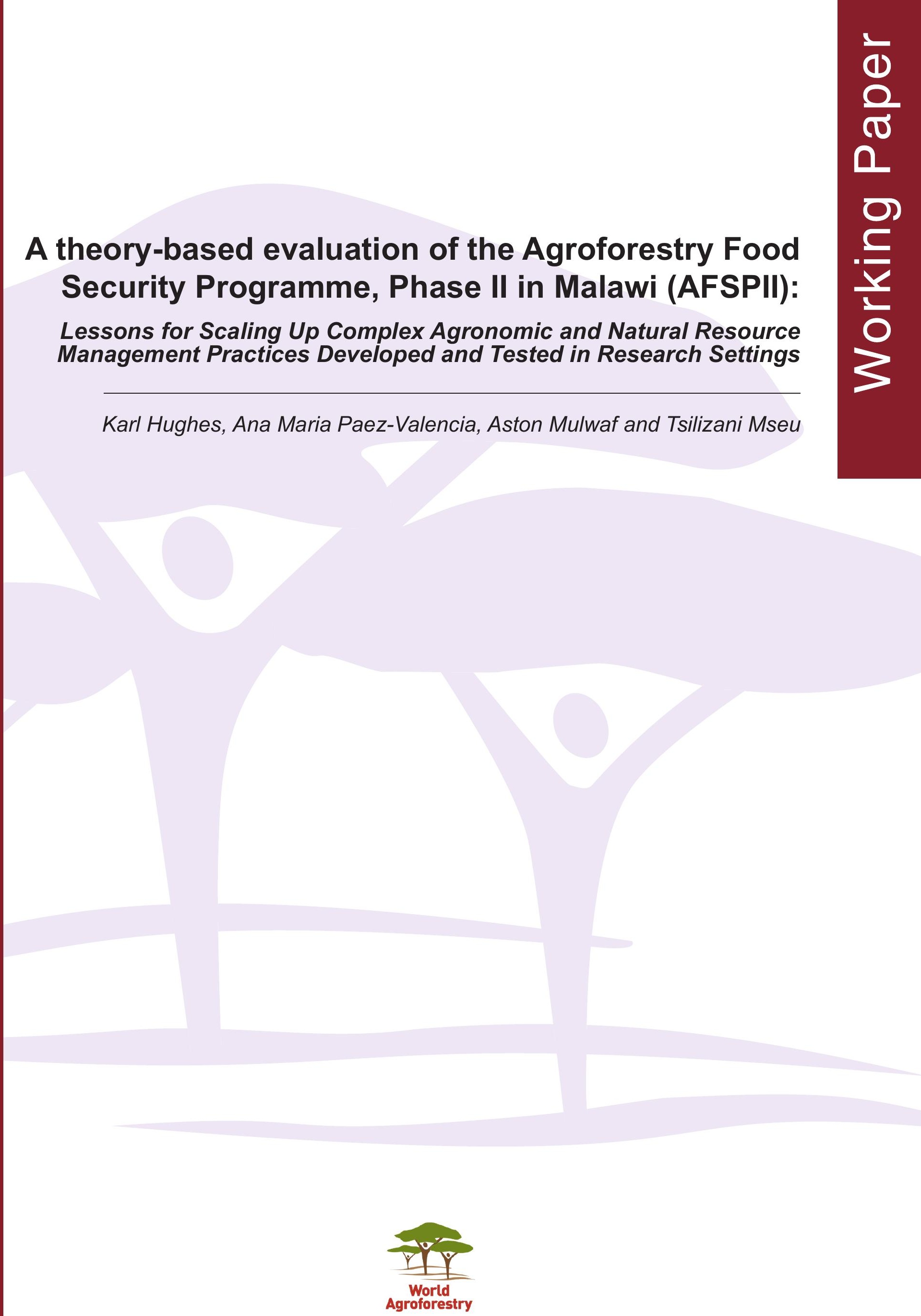




\section{A theory-based evaluation of the Agroforestry Food Security Programme, Phase II in Malawi (AFSPII): Lessons for Scaling Up Complex Agronomic and Natural Resource Management Practices Developed and Tested in Research Settings}

Karl Hughes, Ana Maria Paez-Valencia, Aston Mulwaf and Tsilizani Mseu 



RESEARCH

PROGRAM ON

Forests, Trees and

Agroforestry

Correct citation: Hughes K, Paez A, Mulwaf A, Mseu T. 2019. A theory-based Evaluation of the Agroforestry Food Security Programme, Phase II in Malawi (AFSPII): Lessons for the Scaling of Complex Agronomic and Natural Resource Management Practices Developed and Tested in Research Settings. ICRAF Working Paper 300 Nairobi, World Agroforestry. DOI: http://dx.doi.org/10.5716/WP19036.PDF

Published by World Agroforestry

United Nations Avenue

PO Box 30677, GPO 00100

Nairobi, Kenya

Tel: +254(0)20 7224000, via USA +1 6508336645

Fax: +254(0)20 7224001, via USA +1 6508336646

Email:worldagroforestry@cgiar.org

Website: www.worldagroforestry.org

(C) World Agroforestry 2019

Working Paper nr 300

The views expressed in this publication are those of the authors and not necessarily those of World Agroforestry.

Articles appearing in this publication may be quoted or reproduced without charge, provided the source is acknowledged.

All images remain the sole property of their source and may not be used for any purpose without written permission of the source. 


\section{About the Authors}

Karl Hughes is an impact evaluation and monitoring and evaluation (M\&E) specialist who heads ICRAF's Impact Unit. He obtained his PhD - focusing on impact evaluation methodology - from the London School of Hygiene and Tropical Medicine, University of London in 2012. He also holds a Master's Degree in Environmental Studies (1998) from York University, Canada and a Bachelor's Degree in Anthropology and Philosophy (1994) from the University of British Columbia, Canada. Email: k.hughes@cgiar.org

Ana Maria Paez Valencia leads ICRAF's gender integration and inclusion work. She also coordinates the gender cross-cutting theme in the CGIAR Research Programme on Forests, Trees and Agroforestry. Before joining ICRAF, she worked with the Statistics Division and the Gender, Equity and Rural Employment Division of the Food and Agriculture Organization of the United Nations (FAO), supporting the capacity-development strategy for Member Countries on production and use of gender-disaggregated agricultural data, and addressing gender and social equality in agricultural and food security programmes. She has nine years of experience on the design, planning, execution, and M\&E of development projects, particularly on the design of indicators with a gender lens. Email: A.Paez-Valencia@cgiar.org

Aston Mulwaf is a quality assurance, Monitoring \& Evaluation Manager at United Purpose, Malawi. He obtained his Master of Science in agricultural extension from Kerala Agricultural University, India and holds a Bachelor's Degree in Agriculture from the University of Malawi. He has previously held M\&E positions with ICRAF and Self-Help Africa.

Email: aston.mulwafu2010@gmail.com

Tsilizani Mseu is an expert in Agricultural project development, M\&E, applied economics, agricultural engineering and research. He is the Planning, Monitoring and Evaluation Specialist for the Programme for Rural Irrigation Development of the Malawi Government, supported by the International for Agricultural Development (IFAD). He holds a Master of Science Degree in Agricultural and Applied Economics, and a Bachelor of Science Degree in Agriculture, both from the University of Malawi. Email: tsilizanim@gmail.com 


\section{Acronyms}

AFSP Agroforestry Food Security Programme

EPA extension planning area

FAO Food and Agriculture Organization of the United Nations

HFIAS Household Food Insecurity Access Scale

ICRAF World Agroforestry

IFAD International Fund for Agricultural Development

IPWRA inverse probability weighted regression adjustment

M\&E monitoring and evaluation

MDD-W minimum dietary diversity, women

MVR multivariate regression

NGO non-governmental organization

OLS ordinary least squares

PCA principal component factor analysis

PPP purchasing power parity

PSM propensity score matching 


\section{Summary}

This study sought to evaluate the impacts of World Agroforestry's (ICRAF) Agroforestry Food Security Programme, Phase II (AFSPII) in Malawi (2012-2016). Given the absence of a well-planned impact evaluation strategy, a quasi-experimental design grounded in AFSPII's theory of change was designed to take advantage of this programme's geographically staggered roll-out. This was complemented by semi-structured interviews with 40 programme participants and discussions with district-level implementing partners to corroborate the results. The rigour of this evaluation strategy was undermined by the fact that many in the planned comparison group-participants residing in purposively matched villages engaged in AFSPII during its third year - had actually commenced their participation in the first year. Since many participants interviewed in Years 1 and 3 actually resided in the same villages, comparing the two was problematic because: (i) they likely differed in both observable and unobservable ways relevant to the study's outcomes of interest; and (ii) the Year 3 participants from these villages may have been influenced by their interactions with Year 1 participants. This issue was exacerbated by the fact that only $53 \%$ of the targeted sample size was attained and baseline data could only be reconstructed for a few key variables (e.g. household assets). While several econometric models were used to control for observable differences between the two groups, these limitations are explicitly recognized.

Nevertheless, several relevant lessons were generated, particularly from the study's examination of the uptake of promoted agroforestry practices among AFSPII participants, as well as the contextual factors influencing this. Only a small proportion of these participants were able to realize the targets set for the four promoted agroforestry practices. For example, for the programme's core intervention-fertilizer tree promotion-only $14 \%$ of the Year 1 participants incorporated either a moderate or significant amount of fertilizer tree biomass into their fields prior to maize planting in both Years 2 and 3. It is therefore unsurprising that no significant average differences for the various outcome and impact measures were found in the comparison of Year $1(n=402)$ and Year $3(n=229)$ participants, except for a modest decrease in time spent collecting firewood. The study concludes with three recommendations:

(1) Build in systematic provisions for participatory monitoring, follow-up support, and adaptive management when scaling complex agronomic and natural resource management interventions.

(2) Expand the research cycle to encompass the scaling effort, particularly when there is uncertainty about technology and practice uptake or performance, including how they interact with the socio-economic and biophysical characteristics of "real world" settings.

(3) Ensure that an appropriate impact evaluation strategy is pursued from the outset, viewing it as an integral part of the larger research effort. 


\section{Contents}

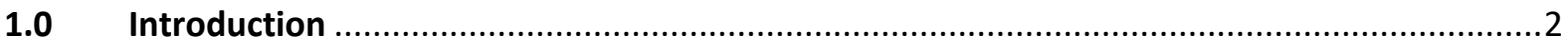

2.0. Brief background on fertilizer tree development and promotion efforts............................

3.0. The Agroforestry Food Security Programme, Phase II (AFSPII) and its theory of change.......5

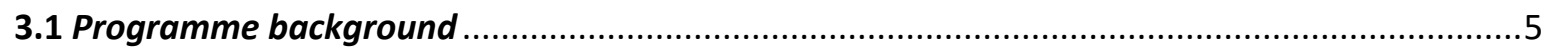

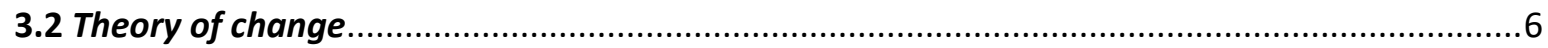

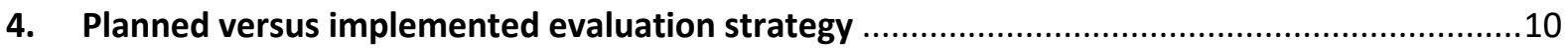

4.1 Planned impact design (identification strategy) .......................................................10

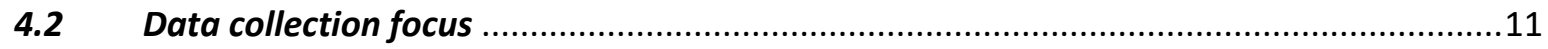

4.3 Preparation for data collection and AFSPII participant sampling ..................................11

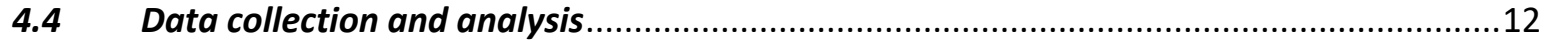



4.6 Qualitative follow-up interviews and analysis............................................................14

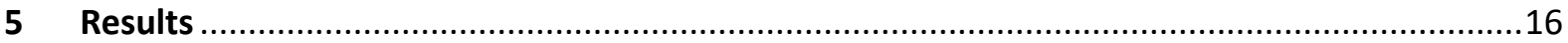

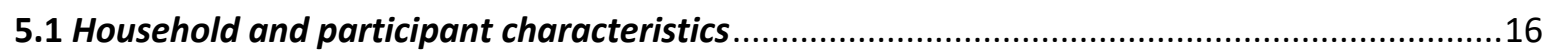

5.2 Uptake of promoted fertilizer trees and associated practices .................................................18

5.2.1 Fertilizer trees found in sampled maize fields during the household survey .......................18

5.2.2 Intercropping of promoted fertilizer tree species with maize .............................................20

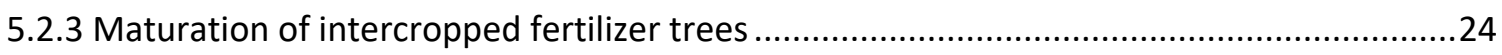

5.2.4 Incorporation of biomass from intercropped fertilizer trees ..............................................26

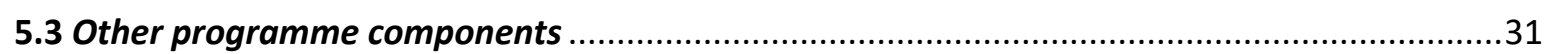



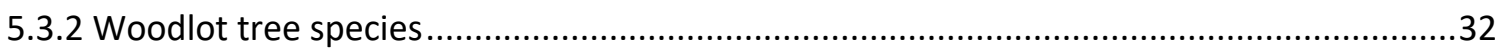

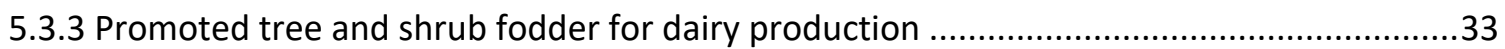

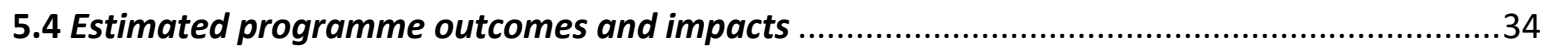

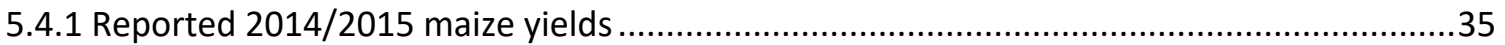

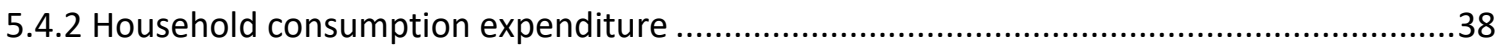

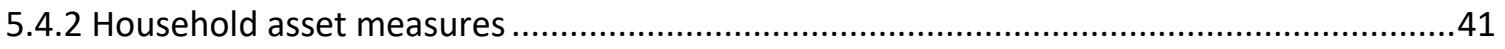

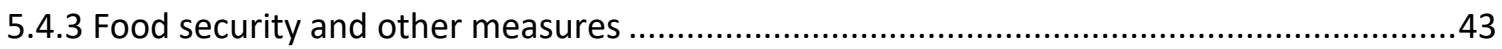

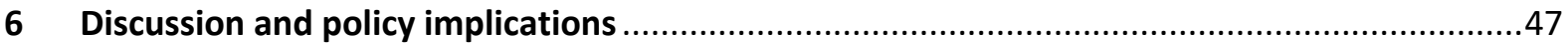

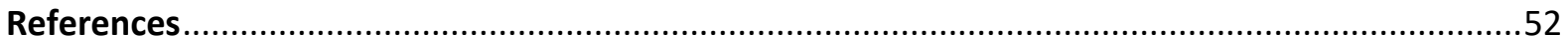

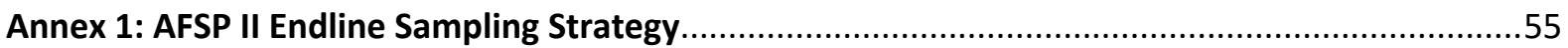

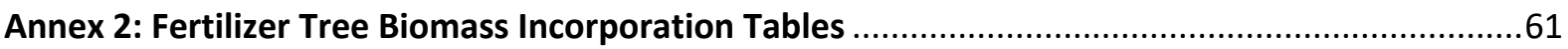

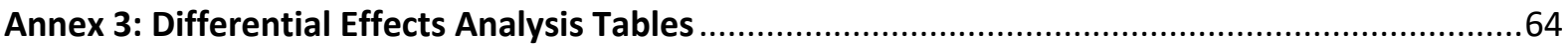

Annex 4: List of Binary Household Assets and Other Wealth Indicators .......................................72

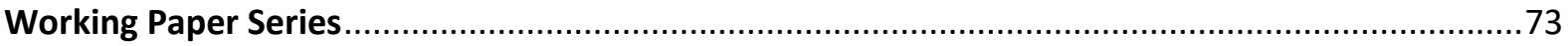




\subsection{Introduction}

This report documents an attempt to evaluate the impacts-defined here as both the shorter-and longer-term causal effects of an intervention - of the second phase of the Agroforestry Food Security Programme (AFSPII). Funded by Irish Aid, this programme was led by World Agroforestry (ICRAF) and implemented in partnership with district-level government offices and several non-governmental organization (NGOs) in the Mzimba, Dedza and Thyolo districts in Malawi from April 2012 to March 2016. AFSPII sought to improve the food security, nutrition, income, and livelihoods of over 30,000 smallholder farmers and increase the resilience of the farm environment through the promotion of "fertilizer trees" and other tree species for fruit, fodder, timber and fuel wood. ${ }^{1}$

While baseline and endline surveys were undertaken for this programme, they were not informed by an appropriate impact evaluation strategy. It was assumed that AFSPII's impact could be assessed by comparing the status of particular outcomes (e.g. maize yields and food security) among participating farmers before and after the programme's implementation. However, before-and-after analysis is viewed as an inappropriate approach to evaluating programme impact given the myriad of nonprogrammatic factors that can influence these outcomes over time, including changes in rainfall patterns and government policies (Gertler et al. 2016). Consequently, we found the impact-related conclusions documented in AFSPII's externally commissioned evaluation report to be unreliable. ${ }^{2}$

Moreover, in the absence of an appropriate impact evaluation strategy, we were challenged in credibly assessing AFSPII's impact, particularly when our engagement started only in the programme's final year of implementation. We therefore undertook a scoping mission several months before administering our survey (August 2015) to learn more about the programme and undertake an impact evaluation feasibility assessment. In the process, we learned that the programme had started in selected villages within each district and was rolled out to additional villages in subsequent years. As described in greater detail in Section 4, we took advantage of this by purposively matching Year 1 and Year 3 villages, and comparing programme participants within the two resulting sets of villages. We complemented this approach by: (i) reconstructing baseline data for several variables assumed to be reliably recalled with the use of locally appropriate historical markers; (ii) fleshing out the programme's theory of change to assess progress along impact pathways; and (iii) conducting followup qualitative interviews with a subsample of previously interviewed AFSPII Year 1 participants.

This report focuses on both the process and results associated with this theory-based quasiexperimental impact evaluation. The following section starts by placing the study in the context of the literature, with a focus on AFSPII's core intervention-promoting the integration of fertilizer trees in maize fields. Section 3 describes the programme and its theory of change, while sections 4 and 5 describe the evaluation's planned versus actual implementation and key findings respectively. Section 6 concludes with a short discussion and recommendations for future scaling initiatives.

\footnotetext{
${ }^{1}$ ICRAF. (2012) Agroforestry Food Security Programme (AFSP) in Malawi: Phase II Proposal

${ }^{2}$ Kirk Development Research, Training and Consultants. (2016) Final Report: End of Programme Evaluation for Agroforestry Food Security Programme Phase II. Lilongwe.
} 


\subsection{Brief background on fertilizer tree development and promotion efforts}

Considerable research has taken place since the 1980s-especially in southern Africa-on the extent to which particular tree and shrub species (popularly called fertilizer trees) can sustainably improve soil health in general and soil fertility in particular in order to bolster crop production and improve food security (Ajayi et al. 2011). Many studies conducted in agricultural research stations and farmers' fields reported positive results (see: Kwesiga and Coe 1994; Kamanga, Kanyama-Phiri and Minae 1999; Chintu et al. 2004). Indeed, Sileshi et al.'s (2008) meta-analysis of 94 peer-reviewed publications found that maize yields can be doubled or tripled relative to unfertilized maize in $67 \%$ and $45 \%$ of cases with coppicing and non-coppicing fertilizer tree species respectively. In addition to enhancing soil fertility, there is evidence that fertilizer trees also: suppress weeds and pests; improve water and nutrient cycling; increase the presence of beneficial soil organisms; and sequester carbon (Sileshi and Mafongoya 2006; Chirwa et al. 2007; Akinnifesi et al. 2010; Makumba et al. 2007). With the cost of inorganic fertilizers beyond the reach of many smallholder farmers, coupled with widespread soil degradation resulting from a long history of unsustainable soil management practices, fertilizer tree systems are potentially highly relevant (Ajayi et al. 2011).

Given the positive outcomes of this research, it is not surprising that there have been efforts to promote fertilizer trees among smallholder farmers. While this report focuses on the second phase of one such attempt-the Agroforestry Food Security Programme (AFSP) in Malawi-there have been several others as well. For example, the Zambian Conservation Farming Unit promoted Faidherbia albida planting alongside other conservation agriculture practices, such as minimal tillage and mulching (Garrity et al. 2010). Another is the Integrated Agroforestry Project led by World Vision in Zambia's Eastern Province, which promoted improved fallows using fertilizer tree species, such as Sesbania sesban, Tephrosia vogelii, pigeon peas (Cajanus cajun) and Gliricidia sepium (Peterson et al. 2004). A final example comprises the "re-greening success" experienced in large parts of Niger and other West African countries that was reportedly driven by the promotion of farmer-managed natural regeneration ${ }^{3}$ (Tougiani, Guero and Rinaudo 2008).

However, Coe et al. (2016) argue that much of the evidence on the effects of fertilizer trees on soil fertility, and in turn crop yields, comes from studies carried out at research stations or in researchcontrolled farmer field trials. Under more heterogeneous and imperfect "real world" conditions, such large average effects are unlikely. Moreover, only focusing on the average is likely to mask differences in performance across agro-ecological, social, and economic circumstances. Coe et al. used data collected from a subset of famers participating in the first phase of AFSP to support their argument. These farmers applied fertilizer tree practices promoted by the programme in one maize field and did not implement them in another maize field. The authors then compared the differences in maize yields between the two plots. While they found a modest and positive average difference in favour of the plots with fertilizer trees, they also found significant variation around this average. In fact, between $18 \%$ and $33 \%$ of the plots applying the promoted fertilizer tree practices were found to produce less maize than the sole maize plots.

Sileshi and Akinnifesi (2017) challenged Coe et al.'s methods and conclusions on two key points. First, the practices applied on the fertilizer tree (i.e. "treated") plots varied significantly: on some, mature trees (e.g. Faidherbia albida) had been planted decades ago while others had shrubs such as Gliricidia sepium, where there was considerable (and uncontrolled for) variation in the frequency and method of coppicing and soil incorporation. Second, management practices on the "sole maize" plots also

\footnotetext{
${ }^{3}$ Farmer-managed natural regeneration involves the systematic selection, pruning and protection of stems sprouting from living tree stumps and natural seedling regeneration (Tougiani, Guero, and Rinaudo 2008).
} 
varied considerably: some were fully fertilized with inorganic fertilizer, while others were only partly fertilized and/or applied with animal manure or nothing at all. Sileshi and Akinnifesi pointed out that while Coe et al. (2016) acknowledged some sources of heterogeneity, they did not adequately address these sources when calculating yield differences. In their reply to Sileshi and Akinnifesi's critique, Coe et al. (2017) argued that, "It is valid and useful to look at the actual effect on crop yield of farmers having trees intercropped with maize, rather than controlling for how the crop is managed, because this is what happens in the real world....Attempts to eliminate this will result in measuring an artefact rather than the real impact of trees on crop yield".

It is clear that this evaluation took place in a context in which there was: (i) considerable interest in the potential benefits associated with the integration of appropriate fertilizer tree species and practices into crop fields; and (ii) scientific debate on the effectiveness of fertilizer trees for farmers residing in diverse agro-ecological, social, and economic contexts. As will be elaborated in the conclusion section, our evaluation finds both merits and limitations in the arguments put forward by Coe et al. (2016) and Sileshi and Akinnifesi (2017). We complement these findings with recommendations on how the research on and promotional efforts associated with fertilizer trees (and similarly complex agronomic and natural resource management interventions) can be taken forward. 


\subsection{The Agroforestry Food Security Programme, Phase II (AFSPII) and its theory of change}

\subsection{Programme background}

ICRAF commenced implementing the first phase of AFSP in January 2007 in 11 districts of Malawi within 24 extension planning areas (EPAs). It is reported that 184,463 farming households (out of a total target of 200,000) were directly reached by the programme, which aimed to promote the integration of fertilizer trees in maize fields, coupled with the planting and management of trees for fruit, fodder, and wood fuel (Beedy et al. 2012).

However, an external review of Phase I concluded that it attempted to achieve too much over too large a geographic area given the available resources. Therefore, AFSPII-which ran from April 2012 to March 2016-was scaled back to three districts (Mzimba, Dedza and Thyolo) and 12 EPAs, with the aim of reaching 30,240 households; $94 \%$ of this target is reported to have been achieved. ${ }^{4}$ The programme specifically sought to improve the food security, nutrition, income, and livelihoods of these households, as well as the resilience of the farm environment. Its specific objectives were to:

(i) Adapt and target fertilizer, fruit, fodder and timber trees to appropriate niches where they could improve crop and livestock productivity, and resilience to risks;

(ii) Improve local and national tree germplasm supply and delivery systems in order to enable farmers' timely access to high-quality tree seed and seedlings;

(iii) Strengthen the capacity of national and local institutions, NGOs and community-based organizations in scaling up agroforestry to achieve evergreen and climate-smart agriculture in Malawi;

(iv) Engage policy makers in formulating appropriate policy instruments to mainstream agroforestry at the national level; and

(v) Demonstrate the potential contribution of agroforestry to food security and carbon sequestration in order to mitigate climate change among households practicing agroforestry. ${ }^{5}$

Similar to its first phase, ASFPII promoted:

1. fertilizer trees-Tephrosia vogelii, Gliricidia sepium, Faidherbia albida, and pigeon pea (Cajanus cajun) - together with conservation agriculture to establish evergreen agriculture that enhances the accumulation of organic matter in soil, enhancing crop productivity and resilience to climatic risks;

2. fruit trees to improve household nutrition, health and income;

3. fodder trees to improve milk yields for smallholder dairy farmers, enhancing nutrition, health and income; and

4. woodlots for firewood and timber production.

AFSPII was mainly implemented by district agricultural extension officers in each of the three districts, with support from NGOs targeting specific EPAs. These included the National Smallholder Farmers' Association of Malawi in Mzimba District; the Catholic Development Commission in Malawi in Dedza District; and Concern Universal in Thyolo District. Hereafter, both district agricultural extension officers and NGOs are referred to as implementing partners.

\footnotetext{
${ }^{4}$ Kirk Development Research, Training and Consultants. (2016) Final Report: End of Programme Evaluation for Agroforestry Food Security Programme Phase II. Lilongwe.

${ }^{5}$ ICRAF. (2012) Agroforestry Food Security Programme (AFSP) in Malawi: Phase II Proposal. Nairobi.
} 


\subsection{Theory of change}

During our first scoping visit to Malawi in August 2015, we meet with the ICRAF country team involved in designing and implementing AFSPII. We sought to work with them in order to understand the programme's underlying theory of change with respect to its direct support to smallholder farmers. The process can be described as follows:

1. Mobilization. AFSPII was to identify lead farmers, who were to work with implementing partners to mobilize and register farmers in each targeted EPA to participate in the programme.

2. Germplasm provision and capacity development. The implementing partners were then expected to work with these lead farmers to provide fertilizer tree germplasm to all registered farmers (using one or more of the four practices listed above, depending on their preferences), along with complementary training and extension support. Given supply limitations, subgroups of targeted farmers were also to have received grafted fruit tree seedlings, timber, fuelwood, fodder tree seeds, ${ }^{6}$ training, and extension support.

3. Establishment and management of tree nurseries. Farmers were then expected to establish and managed nurseries (either individually or through groups) for Gliricidia sepium, Faidherbia albida, fodder, and woodlot species.

4. Tree planting and management. The participating farmers were then expected to plant the tree seeds or seedlings (depending on the species) and undertake follow-up tree management as per their training (e.g. incorporating tree leaf biomass into the soil prior to planting and periodically as the crops grew). They were also expected to implement complementary conservation agricultural practices, such as mulching.

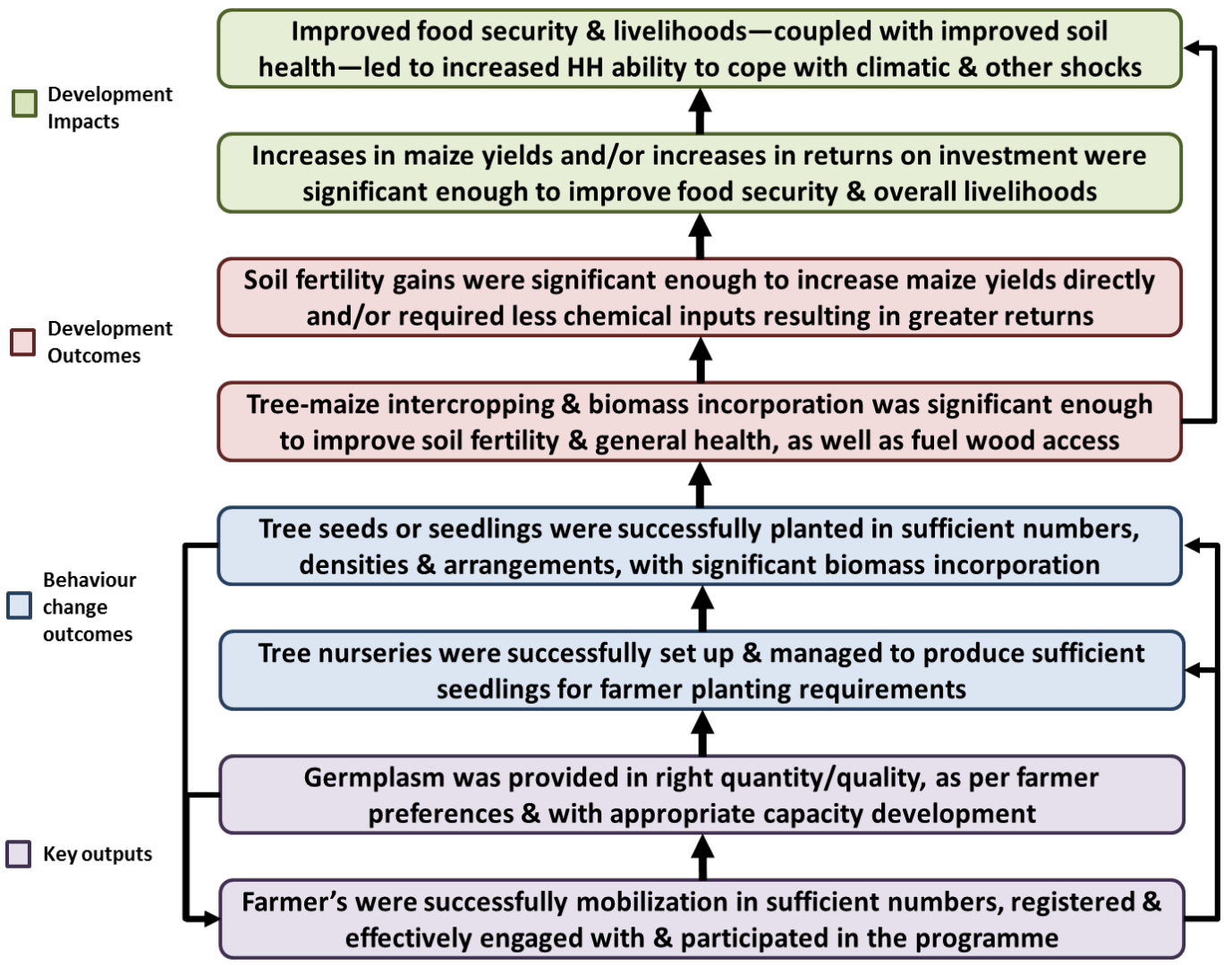

Figure 1: Theory of change focusing on AFSPII's fertilizer tree component

\footnotetext{
${ }^{6}$ Fodder trees were only promoted in three EPAs where dairy farming is commonly practiced.
} 
5. Intermediary benefits. Increased soil fertility, water and nutrient cycling, and access to firewood was then expected to take place among those who received Tephrosia volgelii and fuelwood species (thereby, reducing women's time collecting firewood), as well as reduced soil erosion. Among those who received other types of tree seeds and seedlings, fodder was to be fed to cattle in the right quantity and times and the fruit trees matured, followed by sales and consumption of the fruits and sharing of scions to others.

6. Increase agricultural production, income and diversification. As a result, sustainable increases agricultural production, more diversified household incomes and food sources, and reduced workloads for women were expected.

7. Improve food security, livelihoods and resilience. Long run impacts were then expected, includiing increased household resilience to climate change and other shocks, and sustained increases in household income and food and nutrition security.

Figure 1 details AFSPII's theory of change, with a focus on the project's core component-promoting the integration of fertilizer trees in maize fields. It explicitly emphasizes the conditions required for each step to lead to subsequent steps, starting from the key outputs to be delivered, progressing to the resulting behavioural changes by farmers and continuing to the expected outcomes and impacts.

It is worth noting that the programme team had specific targets for applying the promoted agroforestry practices among participating farmers. These were largely identified through previous research (including the studies cited in Section 2), which determined how many fertilizer trees needed to be successfully intercropped with maize in order to generate soil fertility benefits. These targets, presented below, are highly relevant for this study given that their realization was a necessary precondition for AFSPII to generate expected outcomes and impacts.

- Tephrosia volgelii: The Tephrosia volgelii seeds provided to participating farmers needed to be under-sown as hedges adjacent to maize planting lines at a density of 600 grams of seed per 0.3 hectare, resulting in approximately 16,000 shrubs per unit of land. The established shrubs then needed to grow to a high density together with the planted maize (i.e. not taken out as weeds or destroyed during harvesting, by fire or by livestock). During the next planting season, the Tephrosia volgelii shrubs were to be cut down entirely, with the leaf biomass incorporated into the soil 3-4 weeks prior to maize planting. The branches could then be used or sold as firewood. The targeted farmers were also encouraged to keep several Tephrosia volgelii trees (e.g. along field boundaries) to serve as seed banks. This system is referred to as annual relay intercropping.

- Pigeon pea (Cajanus cajun): The targets and approach for pigeon pea maize intercropping were similar to those for Tephrosia volgelii. Density was also targeted at 16,000 successfully established shrubs per 0.3 hectare and planted as hedges adjacent to maize planting lines. A key difference is that the seeds-which are harvested in July following the harvesting of maize in April-can be consumed. The intercropping of pigeon pea with maize was reported to be a common practice in Thyolo District even prior to AFSP

- Gliricidia sepium: These seeds needed to germinate in nurseries and be raised into seedlings prior to being intercropped as hedges adjacent to maize planting lines. The targeted density was 2,667 established shrubs per hectare. They were to be cut back three times per year as the shrubs matured to avoid competition with the adjacent maize plants. The leaf biomass resulting from each round of cutting was to be incorporated into the soil: once prior to maize seed sowing (like Tephrosia volgelii); and then twice during plant growth. As for Tephrosia volgelii, the Gliricidia sepium shrubs were not to be uprooted and replanted each year. Instead, once established, they were allowed to continue growing for several farming seasons with periodic pruning. 


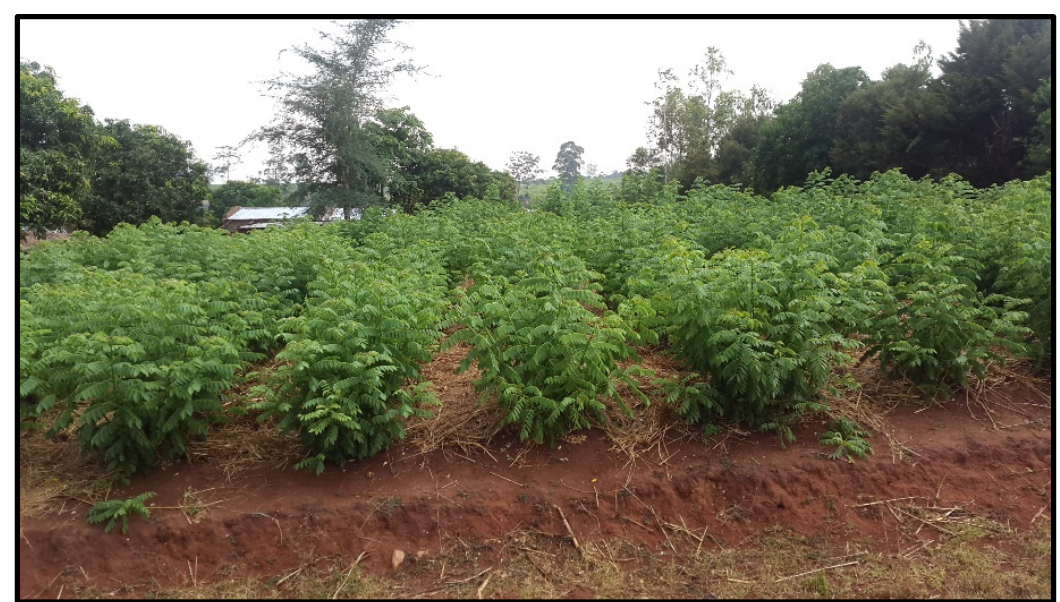

Photo 1: Gliricidia sepium system with mulching prior to incorporation and 2016/2017 maize seed sowing. Source: AFSPII participant, Thyolo District (qualitative follow-up survey, October, 2016)

- Faidherbia albida: This fertilizer tree technology is meant to function quite differently from the three shrub-based technologies described above. Faridherbia albida seeds (like Gliricidia sepium) are best germinated and raised into seedlings in nurseries. The resulting seedlings were then planted 5 by 5 meters apart within the maize fields so that a target of at least 60 trees per 0.3 hectares could be reached. Successfully established Faidherbia albida seedlings take anywhere between seven to 15 years to mature. Consequently, any possible benefits associated with new Faidherbia albida establishment could not be expected until several years after programme implementation. However, once matured, the exfoliated leaves are expected to improve soil fertility along with soil, water, and microclimatic conditions below the tree (Spevacek 2011).

- Grafted fruit trees: It is reported that over 1,300 participating farmers were provided with grafted fruit tree seedlings (mango, avocado, and citrus). ${ }^{7}$ These seedlings served as "mother blocks" enabling other participating farmers to access scions needed to produce grafted seedlings for establishing their own fruit orchards. The target was for each mother block farmer participant to successfully establish an orchard of at least 20 grafted fruit trees containing two or three species, which could be used to provide scions for other farmers to establish their own orchards.

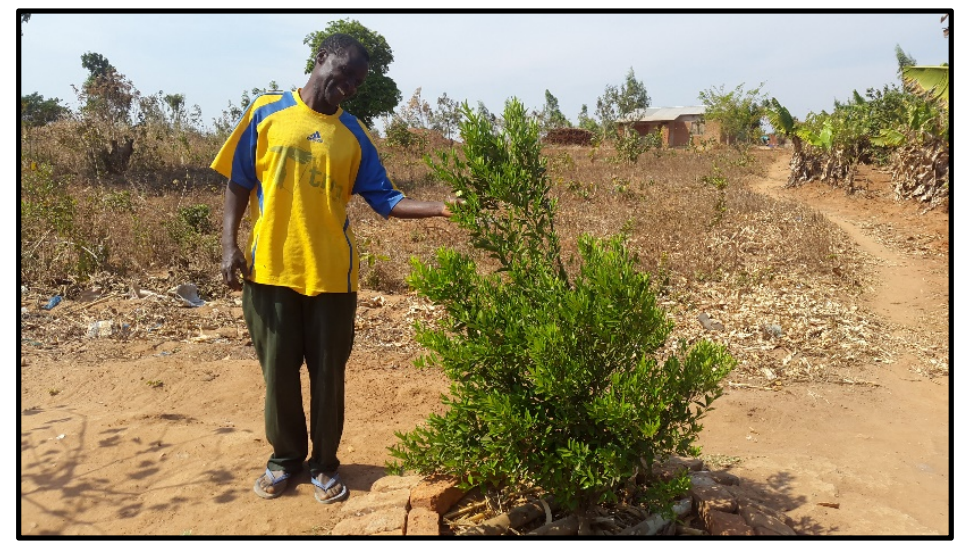

Photo 2: Grafted mandarin orange tree. Source AFSPII participant, Mzimba District (qualitative follow-up survey, October, 2016)

\footnotetext{
${ }^{7}$ ICRAF. (2015) Annual Technical Report: January to December, 2014.
} 
- Woodlot tree species: A small proportion (1.4\%) of the farmers targeted by AFSPII were supported to establish either individual woodlots or replenish existing village forest areas. ${ }^{8}$ These farmers were expected to successfully establish at least 222 of the promoted woodlot tree species - Senna spectabili, Senna siamea, Albizia lebbeck and Alfezelia quanzesis.

- Fodder tree species: Only three of AFSPII's 12 targeted EPAs are dairy producing areas, and only a small proportion of farmers in these areas keep dairy cows. Therefore, the promotion of fodder trees was only directed at these farmers. To ensure the sufficient production of protein-rich leafy matter needed to enhance milk production, each supported dairy farmer was expected to have at least 1,777 healthy fodder tree species-Acacia angustissima, Leucaena trichandra, Leucaena pallida, L. esculenta and Calliandra calothyrsus-as fodder banks.

${ }^{8}$ Ibid. 


\section{Planned versus implemented evaluation strategy}

\subsection{Planned impact design (identification strategy)}

While AFSPII carried out both baseline and endline surveys, they were not complemented by the design and implementation of an appropriate impact evaluation strategy. The assumption was that AFSPII's impact could be evaluated by outcome and impact indicators before and after the programme's implementation. However, this impact evaluation strategy is problematic due to the multitude of non-programmatic variables (e.g. variation in rainfall) that can bias estimations of programme impact (Gertler et al. 2016).

Consequently, one of the objectives of our first scoping mission to Malawi in August, 2015 was to explore whether a reasonably credible ex-post impact evaluation strategy could be pursued. We were confronted with the need to address three key sources of potential bias (White 2010):

(a) Programme placement bias: Villages targeted by the programme could differ in relevant ways from comparison villages (e.g. proximity to roads and markets).

(b) Self-selection bias: Farmers opting into the programme may have different characteristics (in both observable ways such as educational attainment and unobservable ways such as motivation) from comparison farmers who did not participate in AFSPII. Indeed, they may have already been better off in relation to critical outcome and impact measures.

(c) Contagion or programme spill-over effects: The newly acquired knowledge, skills, and/or germplasm associated with the promoted agroforestry practices could have been shared with these comparison farmers.

As we learned more about AFSPII's implementation in the 12 targeted EPAs, we came to understand that not all villages were engaged at the same time. For example, implementation began in some villages in the 2012/2013 farming season (Year 1), in others in 2013/2014 (Year 2), and in still others in 2014/2015 (Year 3). This staggered rollout of the programme opened up the possibility of pursuing a quasi-experimental design that would attempt to mimic a randomized phase-in design. In this design, all participants are ultimately able to participate in the programme. However, the timing of this offering is randomly determined, with those joining later serving as comparators to those who joined earlier (Glennerster and Takavarashra 2013). Given that the farmers who joined the programme in $2014 / 2015$ could not have realistically benefitted from the promoted fertilizer trees (particularly biomass incorporation) or other programme components in any significant way by time of data collection, we inferred that a carefully selected subset of these farmers could serve as a reasonable estimation of the counterfactual (what would have happened if Year 1 farmers had never participated in AFSPII).

We also took advantage of the fact that AFSPII had established a database with the names of all participating farmers, their respective villages, and dates of programme engagement. This enabled villages engaged in Year 1 to be differentiated from those primarily engaged in Year 3. The study's original village sampling strategy is presented in Annex 1 . The purposive matching of villages based on the criteria presented in this strategy was intended to mitigate programme placement bias. Moreover, interviewing only (a) farmers who engaged in the programme in Year 1 from Year 1 villages and (b) those who engaged in Year 3 from Year 3 villages was intended to blunt (if not eliminate) self-selection bias. Our assumption here is that farmers in a village who are first to engage with a typical community development programme likely differ in relevant observable and unobservable ways from those who engage later or never engage at all from that same village. Finally, comparing Year 1 and Year 3 farmers from different villages significantly reduces (but, again, does not necessarily eliminate) the likelihood that estimated programme outcomes and impacts would have been confounded by spill-over effects. 


\subsection{Data collection focus}

This study adopted a theory-based design (White 2009), which is why we worked with the ICRAF Malawi programme team to flesh out AFSPII's underlying theory of change. Consequently, we designed the survey instrument and complementary data-collection activities to test different aspects of this theory of change along the causal chain towards the final expected impacts. As mentioned above, not all AFSPII participants were supported to pursue all four practices, except for fertilizer tree intercropping. Screening questions were integrated into the survey instrument and only respondents who reported pursuing these additional practices were asked about them.

Given that many of AFSPII's expected outcomes and impacts were contingent on the extent to which the participants were able to put into practice the promoted fertilizer tree technology, a number of questions were asked to ascertain this. Making use of pictures (see subsection 5.2), respondents were queried about the number of times they attempted to intercrop the fertilizer trees in their maize fields and the quantity of fertilizer tree biomass they incorporated. Questions were then asked to capture data on these expected outcomes and impacts such as maize yields, firewood access, perceived soil fertility, various measures of food security, household consumption expenditure, asset ownership, and other indicators of household wealth.

Finally, we were interested in assessing whether male and female participants took up AFSPII's interventions in different ways. To assess this, the survey included a number of questions designed to investigate the relationships between gender roles and the management and care of seedlings and trees.

\subsection{Preparation for data collection and AFSPII participant sampling}

Two consultants-Gloria Livata and Abel Shaba-were recruited to support and supervise the survey, with ICRAF Malawi's monitoring and evaluation officer, Aston Mulwaf and Field Officer Mwaphongo Konisaga also playing lead roles in coordination and logistical support. A team of 20 young collegeeducated enumerators -10 men and 10 women-was trained to administer the survey instrument, which was developed and field tested based on the Open Data Kit platform. ${ }^{9}$ This training lasted three days and included practice in administering the survey instrument with participating farmers residing outside the study area.

As mentioned above, village sampling was purposively undertaken through qualitative matching to address programme placement bias (i.e. to improve internal validity) at an inevitable cost to external validity and generalizability across the AFSPII programme. A sampling target of 200 households was identified for each district: 100 Year 1 participants and 100 Year 3 participants. Given that we wanted to assess possible differential effects between men and women, efforts were made to interview an even number of both. This was facilitated by the fact that an almost equal number of male and female participants were registered in AFSPII's database.

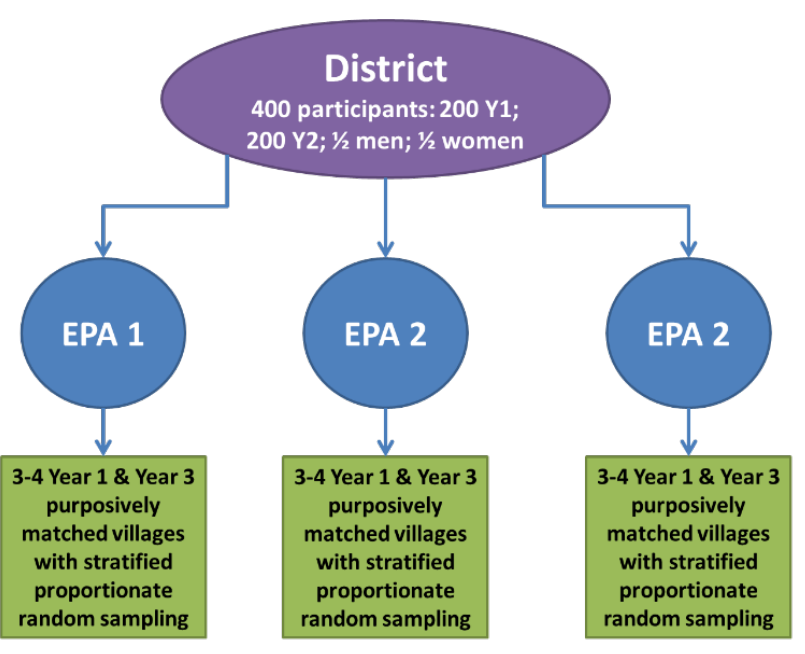

Figure 2: District village sampling strategy

${ }^{9}$ https://opendatakit.org 
Stratified proportionate random sampling was used to select male and female respondents within each district. For example, if a Year 1 village had a total of 20 male participants and the total number of male participants was 200 across all the sampled Year 1 villages, 10 men were randomly selected from the list of 20 for interviews (20/200* district sample quota of 100 Year 1 village men). Consequently, the samples of male and female AFSPII participants are representative of the purposively sampled villages within each of the three districts, but not across the entire programme.

\subsection{Data collection and analysis}

Quantitative data collection took place in October and November 2015. It was first carried out in Dedza District, where the team from ICRAF headquarters observed the process for several days, along with the two consultants and two ICRAF Malawi technical staff. The larger team was sub-divided into two sub-teams, with the Tumbuka-speaking enumerators moving on to Mzimba District accompanied by one of the consultants, and the others moving on to Thyolo District with the second consultant. Once the completed Open Data Kit forms were checked by the consultants or ICRAF technical staff, they were uploaded onto a dedicated online database (administered by Ona $)^{10}$ at the end of each day.

The data were subsequently downloaded and imported into Stata 14 , where they were cleaned and constructed into outcome and impact variables and covariates. For continuous data, such as consumption expenditure and maize yields, outliers were addressed by trimming the data to the $1^{\text {st }}$ and $99^{\text {th }}$ percentiles. For adoption measures, the Year 1 and Year 3 participants were compared directly, without the implementation of statistical (e.g. econometric) models. The rationale was that we wanted to measure directly the extent to which Year 1 and Year 3 participants had taken up the promoted practices (factual analysis).

When comparing the two groups against the outcome and impact measures (counterfactual analysis), several different statistical models were implemented to mitigate potential bias. ${ }^{11}$ These include: (i) ordinary least squares (OLS) regression with robust standard errors; ${ }^{12}$ (ii) inverse probability weighted regression adjustment (IPWRA) or doubly robust regression, which models both participation and outcome (Funk et al. 2011); (iii) robust regression to countervail the influence of extreme values (Verardi and Croux 2009); (iv) propensity score matching (Caliendo and Kopeinig 2005) using kernel weights, particularly because the Year 1 participants had been oversampled; and (v) quintile regression to compare group medians. The independent variables (covariates) included in these models encompassed all those correlated with participation in the Year 1 group below the $10 \%$ level $(p<0.1)$.

Bearing in mind the above-mentioned statistical power limitations, potential differential effects for specific subgroups were also tested. This was done by implementing interaction models for the subgroups in question, and then testing whether the differences in their respective interacted coefficients were statistically different from zero. The specific subgroups were defined by: programme site; participant gender; baseline wealth status; participant education; land holding size; and whether the participant held an official position.

\footnotetext{
${ }^{10}$ https://ona.io/home

${ }^{11}$ Several different models were applied to determine whether the respective treatment effect estimates differed in any meaningful way, thereby serving as a measure of robustness.

12 It is important to note that we would have clustered the standard errors at the village level had our planned impact evaluation design materialized. However, given that both Year 1 and Year 3 participants were present in most of the villages, we did not implement this method.
} 


\subsection{Data collection issues and Implications}

A number of substantive challenges were encountered during the data collection exercise that adversely affected our planned impact identification strategy:

\section{Absence of baseline data}

Given the ex-post, non-randomized nature of our impact evaluation design, we had to address the absence of baseline data, particularly for the Year 1 and Year 3 participants who were to be interviewed. We explicitly recognized that any observed differences between the Year 1 and Year 3 participants could simply reflect their pre-existing baseline differences. In order to address this, attempts were made to reconstruct baseline data with the respondents during the interviews, particularly for items assumed to be reasonably recalled, such as household assets and other wealth indicators. This reconstruction was facilitated by the use of a locally appropriate historical marker. However, for many outcome variables (e.g. maize yields), we did not assume reasonable recall, which limited our analysis of these particular outcome variables and necessitated cautious interpretation. While we did apply a number of advanced statistical methods to control for observable differences between the interviewed Year 1 and Year 3 farmers (as explained in the next section), we explicitly recognize these limitations.

\section{Sample size}

Our targeted sample size of 1,200 was determined more by budgetary constraints than through formal statistical power calculations. Nevertheless, we felt this was sufficient to identify at least moderatesized average effects for most of our outcome variables. However, serious challenges were encountered in the field. Sampled AFSPII participants were often challenging to track down despite attempts by the survey teams and implementing partners to make arrangements beforehand. Funerals were also a complicating factor. Moreover, the survey exercise included a visit to the respondents' primary maize fields, which were often located far from their residences. These issues resulted in enumerators not reaching their daily interview targets. The ICRAF Malawi team was understandably reluctant to extend the timeframe for data collection due to budgetary constraints. As a result, only 631 respondents where successfully interviewed-205 in Mzimba, 221 in Dedza, and 205 in Thyolo.

\section{Dedza District: Two distinct sites}

In hindsight it seems obvious, but we should have treated the two implementing areas in Dedza District as two distinct sites, given that they differ both agro-ecologically and socio-culturally. As indicated on the map below, they are located on different sides of the district, with one area much closer to Lake Malawi and at a significantly lower elevation. Our sampling strategy should have taken this into account to ensure that more AFSPII participants from the implementation area in the west of Dedza District were interviewed. While this was not ideal, we addressed these intra-district differences in the analysis presented in the next section.

\section{Recorded versus self-reported programme engagement timing}

Participants in both Year 1 and Year 3 villages were sampled through AFSPII's database. However, a significant number of interviewed participants from Year 3 villages reported that they had begun participating in AFSPII in Year 1, despite being recorded in the database as starting much later. Problems with AFSPII's database were acknowledged by the ICRAF Malawi team, so we relied on participant self-reports about the timing of their engagement. This impacted the study in several important ways. First, it resulted in an unplanned oversampling of Year 1 participants (64\% of the sample): 402 Year 1 participants versus 229 Year 3 participants. Second, out of the 86 villages where interviews took place, only 33 had farmers that participated in either Year 1 only or Year 3 . The rest had a mix of participants, which undermined many of the theoretical advantages of the planned impact evaluation design described in subsection 4.1.1. 
The counterfactual analysis presented below-the comparison of Year 1 participants and Year 3 participants in relation to various outcome and impact measures-should therefore be interpreted with caution. That said, significant data were collected to enable a factual analysis at key points in the causal chain, including participants' uptake of promoted agroforestry practices. This analysis revealed some of the most relevant and insightful lessons for ICRAF and other actors promoting agricultural and natural resource management interventions among smallholder farmers.

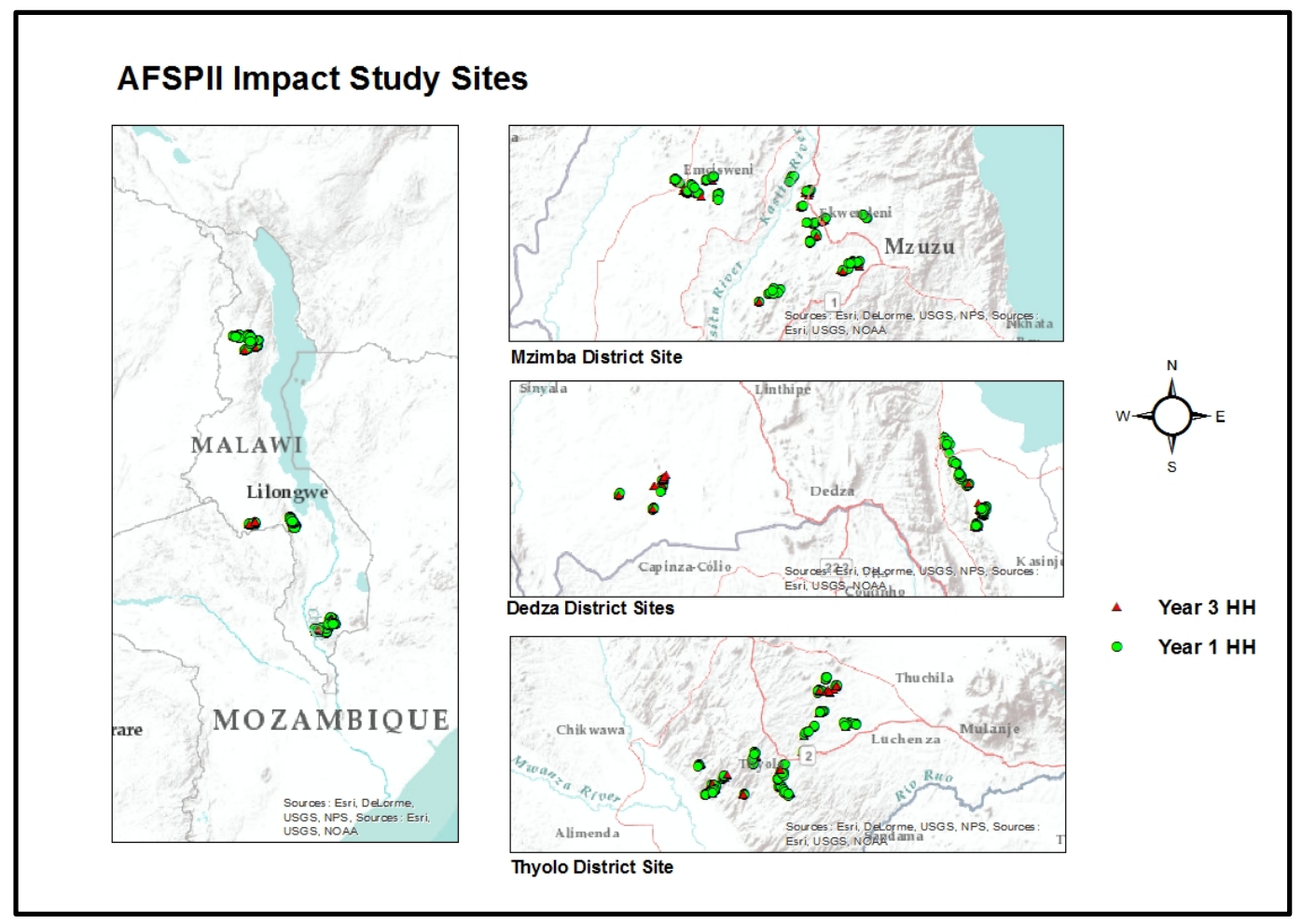

\subsection{Qualitative follow-up interviews and analysis}

The quantitative findings regarding participants' uptake of the promoted practices prompted us to follow up with qualitative data collection in October 2016. We conducted in-depth semi-structured interviews with a sub-sample of 40 purposively selected Year 1 participants from each of the three districts who were interviewed during the quantitative survey period. Using the quantitative data, we classified the participants into the following sub-groups:

(i) "successful adopters" who intercropped in both farming seasons (2012/2013 and 2013/2014) and incorporated a moderate to high quantity of biomass;

(ii) "dis-adopters" who adopted the technology for one season and then stopped;

(iii) "never implementers" who participated in the programme but never took up any of the promoted fertilizer tree systems; and

(iv) "non-incorporators" who intercropped fertilizer trees with maize but never incorporated the biomass.

Our purposive selection of the subsample was largely structured to ensure equal representation from each of these sub-groups, while also taking into account gender and logistical considerations (e.g. ensuring that respondents in each district were geographically close to one another). The 40 qualitative interviews were conducted directly by the research team, ICRAF Malawi's newly appointed senior programme officer (Tsilizani Mseu), and two enumerators who had participated in the quantitative survey. Each interview was recorded, transcribed, and analysed using NVivo software. 
The follow-up exercise was designed to: (i) inquire about factors that might have influenced implementation of the promoted tree fertilizer technology by participant farmers; and (ii) observe farmer perceptions of the benefits of the promoted technology and incentives for its adoption. Efforts were also made to identify gender roles and norms that would influence these perceptions, impacting the effectiveness of the programme's approach. 


\section{$5 \quad$ Results}

\subsection{Household and participant characteristics}

Table 1 presents summary statistics for binary characteristics of the interviewed Year 1 and 3 participants, as well as the differences between them. Given that district effects (and sub-district effects in case of Dedza) are controlled for in our analysis, the differences between the two groups, excluding these site-related differences, are also presented. Indeed, it is these differences that were important to control for in our analysis.

Table 1. Summary statistics: Respondent and household binary characteristics

\begin{tabular}{|c|c|c|c|c|c|c|}
\hline Binary characteristic & $\begin{array}{c}\text { Year } 1 \\
\text { participant }\end{array}$ & $\begin{array}{c}\text { Year } 3 \\
\text { participant }\end{array}$ & $\begin{array}{c}\text { Raw } \\
\text { difference }\end{array}$ & $t$-statistic & $\begin{array}{l}\text { Difference } \\
\text { (net of site) }\end{array}$ & $t$-statistic \\
\hline Female participant & 0.56 & 0.53 & 0.032 & $(0.77)$ & 0.060 & $(0.56)$ \\
\hline Christian & 0.95 & 0.93 & 0.018 & $(0.91)$ & 0.13 & $(0.72)$ \\
\hline Muslim & 0.04 & 0.04 & 0.0030 & $(0.18)$ & -0.050 & $(-0.24)$ \\
\hline Other religion & 0.01 & 0.03 & $-0.021 *$ & $(-1.91)$ & -0.30 & $(-1.00)$ \\
\hline Chewa & 0.19 & 0.27 & $-0.072 * *$ & $(-2.11)$ & -0.065 & $(-0.40)$ \\
\hline Tumbuka & 0.21 & 0.21 & 0.0062 & $(0.18)$ & -0.053 & $(-0.29)$ \\
\hline Lome & 0.28 & 0.22 & $0.061^{*}$ & (1.67) & $0.50 * * *$ & $(2.62)$ \\
\hline Ngoni & 0.24 & 0.17 & $0.071 * *$ & (2.09) & 0.19 & (1.43) \\
\hline Other tribe & 0.07 & 0.14 & $-0.066 * * *$ & $(-2.74)$ & $-0.44 * * *$ & $(-2.97)$ \\
\hline Never married & 0.00 & 0.00 & -0.0019 & $(-0.40)$ & -0.27 & $(-0.54)$ \\
\hline Married with spouse & 0.77 & 0.75 & 0.020 & $(0.57)$ & 0.096 & $(0.83)$ \\
\hline Married but spouse elsewhere & 0.04 & 0.03 & 0.016 & $(1.04)$ & 0.23 & $(1.08)$ \\
\hline Divorced & 0.08 & 0.08 & 0.0016 & $(0.07)$ & 0.024 & $(0.16)$ \\
\hline Widowed & 0.10 & 0.14 & -0.036 & $(-1.37)$ & $-0.24^{*}$ & $(-1.77)$ \\
\hline Respondent is head & 0.66 & 0.68 & -0.020 & $(-0.50)$ & -0.033 & $(-0.30)$ \\
\hline First and only wife of head & 0.33 & 0.29 & 0.038 & $(0.98)$ & 0.100 & $(0.90)$ \\
\hline Respondent has technical skills & 0.02 & 0.02 & -0.000054 & $(-0.01)$ & -0.070 & $(-0.26)$ \\
\hline Respondent health okay & 0.97 & 0.94 & $0.029 *$ & $(1.86)$ & 0.29 & (1.54) \\
\hline Not productive & 0.01 & 0.03 & -0.014 & $(-1.27)$ & -0.26 & $(-1.03)$ \\
\hline Farmer & 0.85 & 0.85 & 0.0017 & $(0.06)$ & 0.060 & $(0.46)$ \\
\hline Small business owner & 0.09 & 0.06 & 0.033 & $(1.48)$ & 0.20 & $(1.18)$ \\
\hline Casual labourer & 0.01 & 0.02 & -0.014 & $(-1.55)$ & $-0.54^{*}$ & $(-1.76)$ \\
\hline Unskilled wage worker & 0.01 & 0.02 & -0.014 & $(-1.55)$ & $-0.53^{*}$ & $(-1.78)$ \\
\hline Skilled wage worker & 0.01 & 0.02 & -0.0050 & $(-0.51)$ & -0.18 & $(-0.65)$ \\
\hline Other occupation & 0.01 & 0.00 & 0.0031 & $(0.47)$ & 0.17 & $(0.39)$ \\
\hline Respondent literate & 0.67 & 0.69 & -0.019 & $(-0.49)$ & -0.090 & $(-0.80)$ \\
\hline Respondent school going & 0.01 & 0.01 & -0.0032 & $(-0.36)$ & -0.13 & $(-0.44)$ \\
\hline Respondent has official role & 0.40 & 0.37 & 0.024 & $(0.60)$ & 0.049 & $(0.46)$ \\
\hline All adults in household over 59 & 0.06 & 0.07 & -0.00083 & $(-0.04)$ & -0.017 & $(-0.10)$ \\
\hline Head is 60 or older & 0.24 & 0.20 & 0.040 & $(1.16)$ & 0.12 & $(0.97)$ \\
\hline Female headed household & 0.25 & 0.24 & 0.0017 & $(0.05)$ & -0.0043 & $(-0.04)$ \\
\hline Literate adult in household & 0.88 & 0.85 & 0.028 & $(1.01)$ & 0.11 & $(0.81)$ \\
\hline Female literate adult in household & 0.66 & 0.65 & 0.015 & (0.39) & 0.019 & $(0.17)$ \\
\hline Household head is literate & 0.74 & 0.74 & -0.0036 & $(-0.10)$ & -0.031 & $(-0.27)$ \\
\hline Household head is productive & 0.99 & 0.97 & $0.019 *$ & (1.91) & $0.48^{*}$ & (1.67) \\
\hline Household farms & 0.99 & 1.00 & -0.0031 & $(-0.47)$ & -0.17 & $(-0.41)$ \\
\hline Household processes crops & 0.04 & 0.04 & 0.0055 & $(0.33)$ & 0.070 & $(0.36)$ \\
\hline Household rears livestock & 0.60 & 0.59 & 0.015 & $(0.37)$ & 0.018 & $(0.17)$ \\
\hline Household operates business & 0.23 & 0.18 & 0.050 & $(1.48)$ & 0.17 & (1.41) \\
\hline \multirow{2}{*}{$\begin{array}{l}\text { Household engages in casual labour } \\
\text { Household engages in formal } \\
\text { employment }\end{array}$} & 0.23 & 0.24 & -0.014 & $(-0.39)$ & -0.068 & $(-0.58)$ \\
\hline & 0.17 & 0.19 & -0.025 & $(-0.81)$ & -0.12 & $(-0.97)$ \\
\hline Observations & 402 & 229 & 631 & & 631 & \\
\hline
\end{tabular}

It is clear from Table 1 that there are ethnic differences between the Year 1 and Year 3 participants, several of which persist after controlling for site-driven differences. The Year 3 participants are also slightly more likely to be widowed and engaged in causal and unskilled wage labour. The heads of Year 3 households are slightly less likely to be engaged in productive work. 
Table 2. Summary statistics: Respondent and household continuous characteristics

\begin{tabular}{|c|c|c|c|c|}
\hline Continuous Characteristic & $\begin{array}{c}\text { Year } 1 \\
\text { participant }\end{array}$ & $\begin{array}{c}\text { Year } 3 \\
\text { participant }\end{array}$ & $\begin{array}{c}\text { Raw } \\
\text { difference }\end{array}$ & $\begin{array}{c}\text { Difference } \\
\text { controlling for } \\
\text { site }\end{array}$ \\
\hline \multicolumn{5}{|l|}{ Averages and differences: } \\
\hline Age (respondent) & 45.95 & 43.06 & $\begin{array}{c}2.92^{* *} \\
(2.35)\end{array}$ & $\begin{array}{l}2.46^{*} \\
(1.89)\end{array}$ \\
\hline Years in village (respondent) & 34.70 & 29.67 & $\begin{array}{c}5.14 * * * \\
(3.45)\end{array}$ & $\begin{array}{c}5.01 * * * \\
(3.29)\end{array}$ \\
\hline Years formal education (respondent) & 5.15 & 4.88 & $\begin{array}{c}0.25 \\
(0.87)\end{array}$ & $\begin{array}{c}0.14 \\
(0.51)\end{array}$ \\
\hline Household size & 5.38 & 4.98 & $\begin{array}{c}0.41 * * \\
(2.32)\end{array}$ & $\begin{array}{l}0.31^{*} \\
(1.82)\end{array}$ \\
\hline Number of adults in household & 2.54 & 2.29 & $\begin{array}{c}0.26 * * * \\
(2.83)\end{array}$ & $\begin{array}{c}0.24 * * * \\
(2.70)\end{array}$ \\
\hline Number of productive adults in household & 2.40 & 2.18 & $\begin{array}{l}0.21 * * \\
(2.46)\end{array}$ & $\begin{array}{c}0.20 * * \\
(2.31)\end{array}$ \\
\hline Number of children in household & 2.84 & 2.69 & $\begin{array}{c}0.15 \\
(1.02)\end{array}$ & $\begin{array}{l}0.071 \\
(0.49)\end{array}$ \\
\hline Years of education head & 5.64 & 5.32 & $\begin{array}{c}0.32 \\
(1.10)\end{array}$ & $\begin{array}{c}0.24 \\
(0.83)\end{array}$ \\
\hline Max. years of educ. of any adult in household & 7.54 & 6.70 & $\begin{array}{c}0.83^{* * *} \\
(2.82)\end{array}$ & $\begin{array}{c}0.73 * * \\
(2.55)\end{array}$ \\
\hline 2011 asset index (PCA weighted) & 0.40 & 0.35 & $\begin{array}{c}0.053^{* *} \\
(2.11)\end{array}$ & $\begin{array}{c}0.053^{* *} \\
(2.30)\end{array}$ \\
\hline 2011 asset index (weighted by 2015 expenditure) & 1.73 & 1.62 & $\begin{array}{c}0.11 * * * \\
(2.80)\end{array}$ & $\begin{array}{c}0.10 * * * \\
(3.11)\end{array}$ \\
\hline Medians and differences: & & & & \\
\hline Age (respondent) & 44 & 40 & $\begin{array}{c}4 * * \\
(2.34)\end{array}$ & $\begin{array}{c}4 * * \\
(2.20)\end{array}$ \\
\hline Years in village (respondent) & 34 & 26 & $\begin{array}{l}8 * * * \\
(4.38)\end{array}$ & $\begin{array}{l}7 * * * \\
(3.66)\end{array}$ \\
\hline Years formal education (respondent) & 5 & 5 & $\begin{array}{c}0 \\
(0)\end{array}$ & $\begin{array}{c}0 \\
(0)\end{array}$ \\
\hline Household size & 5 & 5 & $\begin{array}{c}0 \\
(0)\end{array}$ & $\begin{array}{c}0 \\
(0)\end{array}$ \\
\hline Number of adults in household & 2 & 2 & $\begin{array}{c}0 \\
(0)\end{array}$ & $\begin{array}{c}0 \\
(0)\end{array}$ \\
\hline Number of productive adults in household & 2 & 2 & $\begin{array}{c}0 \\
(0)\end{array}$ & $\begin{array}{c}0 \\
(0)\end{array}$ \\
\hline Number of children in household & 3 & 3 & $\begin{array}{c}0 \\
(0)\end{array}$ & $\begin{array}{c}0 \\
(0)\end{array}$ \\
\hline Years of education head & 6 & 5.5 & $\begin{array}{c}1^{* *} \\
(2.31)\end{array}$ & $\begin{array}{c}0 \\
(0)\end{array}$ \\
\hline Maximum years of education of any adult in household & 8 & 7 & $\begin{array}{c}1 * * * \\
(4.02)\end{array}$ & $\begin{array}{c}1^{* *} \\
(2.39)\end{array}$ \\
\hline 2011 asset index (PCA weighted) & 0.342 & 0.271 & $\begin{array}{c}0.071 * * \\
(2.48)\end{array}$ & $\begin{array}{l}0.053 \\
(1.58)\end{array}$ \\
\hline 2011 asset index (weighted by 2015 expenditure) & 1.58 & 1.52 & $\begin{array}{l}0.054 \\
(0.94)\end{array}$ & $\begin{array}{l}0.031 \\
(0.69)\end{array}$ \\
\hline Observations & 402 & 229 & $631 *$ & 631* \\
\hline
\end{tabular}

$t$ statistics in parentheses

$* \mathrm{p}<0.1, * * \mathrm{p}<0.05, * * * \mathrm{p}<0.01$

$\mathrm{n}=625 / 620$ for baseline asset measures (the construction of these measures is explained in subsection 5.4.2).

The comparison of the two groups in relation to their continuous characteristics (Table 2) reveals a number of additional relevant differences. Year 1 participants are more likely to be older, have larger families, come from more educated households (while not necessarily having more education themselves) and wealthier at baseline. From these data, it is clear that temporal engagement with AFSPII in the surveyed villages was not random. 


\subsection{Uptake of promoted fertilizer trees and associated practices}

This section starts by describing the extent to which promoted fertilizer tree species were found by enumerators in sampled participants' primary maize fields. While this is revealing, it is not a good measure of adoption given that the programme explicitly promoted the integration of these species for specific purposes (see subsection 3.2). The remaining subsections examine this further, from the actual intercropping of trees within respondents' maize fields through incorporation of leafy biomass into the soil.

\subsubsection{Fertilizer trees found in sampled maize fields during the household survey}

At the end of the quantitative interviews with sampled AFSPII participants, the enumerators accompanied them to their primary maize fields. Once there, they made several observations and asked targeted questions about the fields. One question regarded whether there were any trees in the field, and if so, which species. During analysis, these responses were coded according to the fertilizer tree species promoted by AFSPII. Figure 3 displays the results of this analysis while Table 3 reveals the extent to which the differences between Year 1 and Year 3 participants are statistically significant.

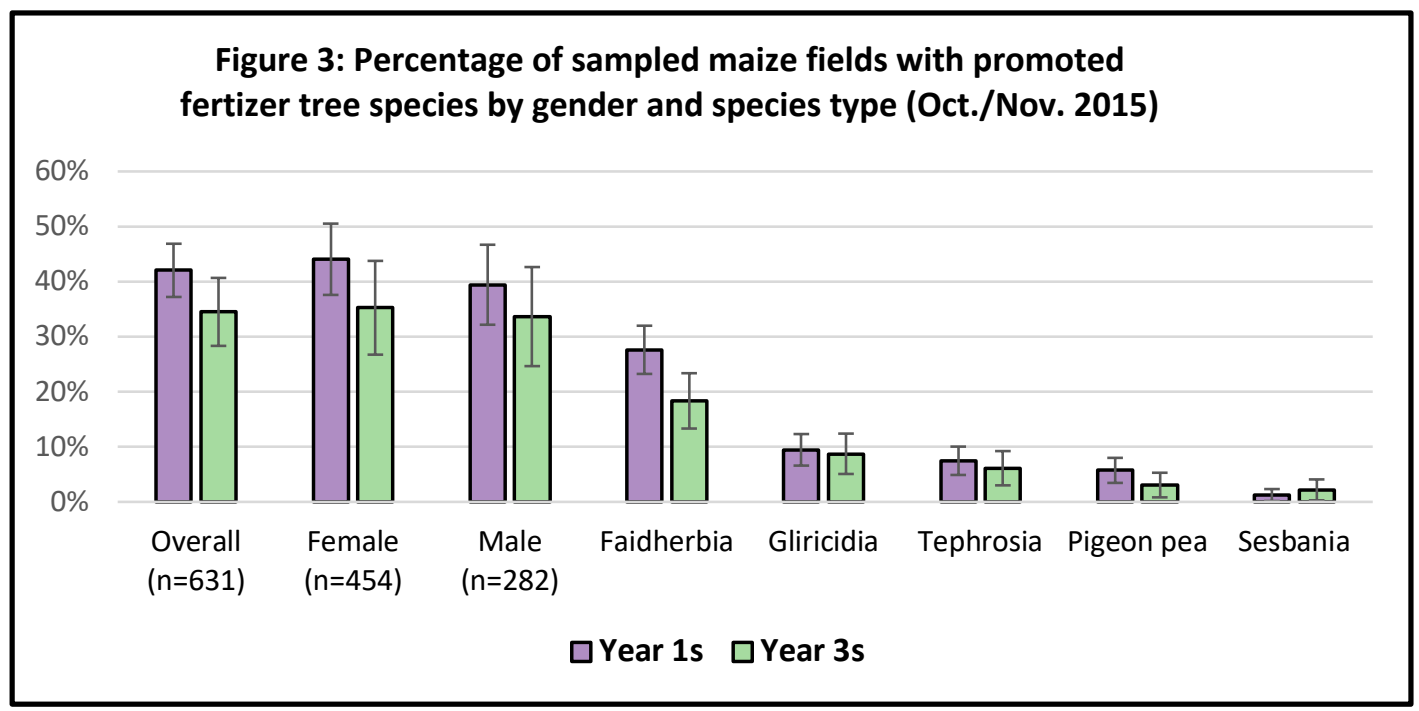

Of Year 1 participant fields, $42 \%$ were found to contain at least one promoted fertilizer tree species compared to $34 \%$ of Year 3 participants' fields-a difference that is statistically significant at the $10 \%$ level. There are minor gender differences, which are not statistically significant. Faidherbia albida was clearly the most commonly found of the promoted fertilizer tree species, with a $10 \%$ statistically significant difference between Year 1 and Year 3 participants. Interestingly, the magnitude of this difference is more significant for female participants in Year 1 than for their male counterparts. It is also worth noting that Faidherbia albida is the only promoted fertilizer tree species for which a statistically significant difference between the two groups was found.

Figure 4 presents the results by survey site, with the data from both Year 1 and Year 3 participants pooled. The Dedza lowland site was found to have the highest proportion of fields found to contain one or more of promoted fertilizer tree species, with Faidherbia albida accounting for the majority of these trees. This corroborated our own observations from three visits to this low-lying location during the study period: large Faidherbia albida trees abounded, often at reasonably high densities. However, the maturity of these trees revealed that they were not a result of AFSPII. 
Table 3. Fertilizer trees identified in sampled maize fields (Year 1 and Year 2 participants \& gender)

\begin{tabular}{|c|c|c|c|c|c|c|c|c|c|}
\hline & \multicolumn{3}{|c|}{ Overall } & \multicolumn{3}{|c|}{ Female } & \multicolumn{3}{|c|}{ Male } \\
\hline Variable & Year 1 & Year 3 & difference & Year 1 & Year 3 & difference & Year 1 & Year 3 & difference \\
\hline Any promoted fertilizer tree & 0.42 & 0.34 & $\begin{array}{c}0.075^{*} \\
(1.87)\end{array}$ & 0.44 & 0.35 & $\begin{array}{l}0.088 \\
(1.60)\end{array}$ & 0.39 & 0.34 & $\begin{array}{l}0.058 \\
(0.97)\end{array}$ \\
\hline Faidherbia & 0.28 & 0.18 & $\begin{array}{c}0.093 * * * \\
(2.61)\end{array}$ & 0.31 & 0.19 & $\begin{array}{l}0.12 * * \\
(2.41)\end{array}$ & 0.23 & 0.18 & $\begin{array}{l}0.057 \\
(1.13)\end{array}$ \\
\hline Gliricidia & 0.09 & 0.09 & $\begin{array}{c}0.0072 \\
(0.30)\end{array}$ & 0.08 & 0.07 & $\begin{array}{c}0.0099 \\
(0.33)\end{array}$ & 0.11 & 0.10 & $\begin{array}{c}0.0058 \\
(0.15)\end{array}$ \\
\hline Tephrosia & 0.07 & 0.06 & $\begin{array}{l}0.013 \\
(0.64)\end{array}$ & 0.07 & 0.07 & $\begin{array}{c}-0.0033 \\
(-0.11)\end{array}$ & 0.08 & 0.05 & $\begin{array}{l}0.033 \\
(1.08)\end{array}$ \\
\hline Pigeon pea & 0.06 & 0.03 & $\begin{array}{l}0.027 \\
(1.51)\end{array}$ & 0.05 & 0.02 & $\begin{array}{l}0.028 \\
(1.24)\end{array}$ & 0.06 & 0.04 & $\begin{array}{l}0.025 \\
(0.92)\end{array}$ \\
\hline Sesbania & 0.01 & 0.02 & $\begin{array}{c}-0.0094 \\
(-0.91) \\
\end{array}$ & 0.01 & 0.02 & $\begin{array}{c}-0.0076 \\
(-0.63) \\
\end{array}$ & 0.02 & 0.03 & $\begin{array}{l}-0.011 \\
(-0.62)\end{array}$ \\
\hline Observations & 402 & 229 & 631 & 227 & 122 & 349 & 175 & 107 & 282 \\
\hline
\end{tabular}

$z$ statistics in parentheses

$* \mathrm{p}<0.1, * * \mathrm{p}<0.05, * * * \mathrm{p}<0.01$

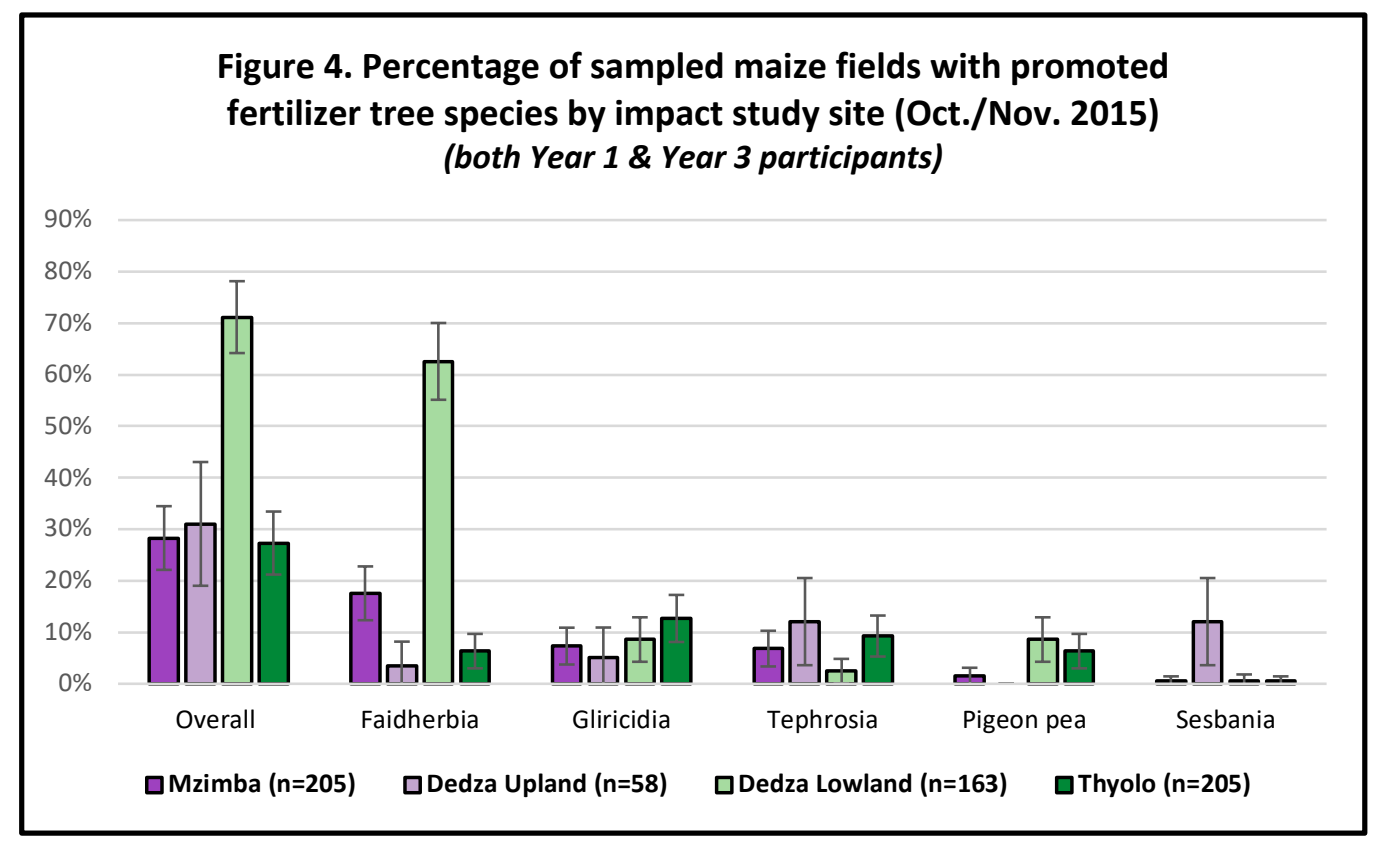

It is important to note that the household survey took place in October, just prior to (and in some areas during) the sowing of maize seeds. It is possible that promoted fertilizer tree species such as Tephrosia and pigeon pea had already been cut down and their leaf biomass incorporated into the soil prior to the enumerators' visits. This would not be expected for either Gliricidia or Faidherbia, however.

Table 4 compares the Year 1 and Year 3 sampled participants by district. Dedza is the only district where statistically significant differences were found between the two groups. This quite large difference of $26 \%$ is driven by both Faidherbia and pigeon pea. We will now look more specifically at how participating farmers actually made use of the promoted fertilizer trees. 
Table 4. Fertilizer trees identified in sampled maize fields (by district)

\begin{tabular}{|c|c|c|c|c|c|c|c|c|c|}
\hline & \multicolumn{3}{|c|}{ Mzimba } & \multicolumn{3}{|c|}{ Dedza } & \multicolumn{3}{|c|}{ Thyolo } \\
\hline Variable & Year 1 & Year 3 & difference & Year 1 & Year 3 & difference & Year 1 & Year 3 & difference \\
\hline Any promoted fertilizer tree & 0.27 & 0.31 & $\begin{array}{l}-0.041 \\
(-0.62)\end{array}$ & 0.71 & 0.45 & $\begin{array}{c}0.26 * * * \\
(3.83)\end{array}$ & 0.28 & 0.26 & $\begin{array}{l}0.020 \\
(0.31)\end{array}$ \\
\hline Faidherbia & 0.18 & 0.17 & $\begin{array}{l}0.010 \\
(0.18)\end{array}$ & 0.57 & 0.32 & $\begin{array}{c}0.25^{* * *} \\
(3.60)\end{array}$ & 0.08 & 0.04 & $\begin{array}{l}0.035 \\
(0.98)\end{array}$ \\
\hline Gliricidia & 0.07 & 0.08 & $\begin{array}{l}-0.017 \\
(-0.45)\end{array}$ & 0.07 & 0.09 & $\begin{array}{l}-0.028 \\
(-0.76)\end{array}$ & 0.15 & 0.08 & $\begin{array}{l}0.069 \\
(1.43)\end{array}$ \\
\hline Tephrosia & 0.06 & 0.08 & $\begin{array}{l}-0.025 \\
(-0.67)\end{array}$ & 0.07 & 0.02 & $\begin{array}{l}0.043 \\
(1.42)\end{array}$ & 0.10 & 0.08 & $\begin{array}{l}0.016 \\
(0.39)\end{array}$ \\
\hline Pigeon pea & 0.02 & 0.00 & $\begin{array}{l}0.022 \\
(1.27)\end{array}$ & 0.10 & 0.00 & $\begin{array}{c}0.10^{* * *} \\
(3.06)\end{array}$ & 0.05 & 0.10 & $\begin{array}{l}-0.050 \\
(-1.42)\end{array}$ \\
\hline Sesbania & 0.01 & 0.00 & $\begin{array}{c}0.0075 \\
(0.73)\end{array}$ & 0.03 & 0.05 & $\begin{array}{l}-0.018 \\
(-0.68)\end{array}$ & 0.00 & 0.01 & $\begin{array}{l}-0.014 \\
(-1.35) \\
\end{array}$ \\
\hline Observations & 134 & 71 & 205 & 136 & 85 & 221 & 132 & 73 & 205 \\
\hline
\end{tabular}

$z$ statistics in parentheses

$* \mathrm{p}<0.1, * * \mathrm{p}<0.05, * * * \mathrm{p}<0.01$

\subsubsection{Intercropping of promoted fertilizer tree species with maize}

All interviewed participants were asked whether they had intercropped any of the promoted fertilizer trees in their maize fields during the last three years. If so, they were then asked in which seasons they intercropped and the types of fertilizer tree species they used. Figure 5 displays the results overall and by gender. There was a statistically significant difference in favour of Year 1 participants overall, but this difference only occurred among female participants. Understandably, there was a much larger difference between the Year 1 and Year 3 participants of both sexes in the 2012/2013 (Year 1) and $2013 / 2014$ (Year 2) farming seasons, given that the latter group had not yet begun participating in the programme. This provided credence to our plan to compare the Year 1 participants with those from Year 3, as explained in subsection 4.1. However, the small increase from Year 1 to Year 2 among the Year 3 participants may be indicative of programme spill-over effects in some villages. Follow-up interviews also revealed that some farmers accessed seeds through channels that were external to AFSPII. For example, five farmers located in different EPAs mentioned receiving seeds through village chiefs.

The other noteworthy observation is that many Year 1 participants did not consistently intercrop over the three seasons; the range is approximately $50 \%$ to $60 \%$ in any given year. Qualitative follow-up interviews revealed that a lack of access to seeds or seedlings, and problems with seed delivery were the most commonly mentioned constraints to consistent intercropping or intercropping across their entire maize fields. However, more than half of the 40 interviewed farmers also mentioned a willingness to implement the practices again if seeds or seedlings were provided.

Table 5 presents the results of statistical proportion tests between Year 1 and Year 3 participants. Note that the Year 3 participants were slightly more likely to intercrop fertilizer trees in Year 3 than Year 1 participants, and there is a gender dimension to this difference: $75 \%$ of Year 3 male participants intercropped fertilizer trees compared with $63 \%$ of their Year 1 male participants. The difference between female Year 1 and 3 participants in Year 3 was not statistically significant.

In the follow-up qualitative interviews, we noted that some respondents may have interpreted the following question differently from how it was intended: "Have you ever attempted to intercrop maize with either pigeon pea, Tephrosia, Gliricidia, Faidherbia, Sesbania, or any other fertilizer tree in the last three years?" We classified participants that answered no to this question as the "never implementers"; however, of the 11 "never implementers" interviewed during the follow-up exercise, nine stated that they did attempt intercropping, but the seedlings either dried up, were washed away by excessive rain or were eaten by goats. It was therefore important to factor this discrepancy into the interpretation of results. 
Figure 5. Reported intercropping of fertilizer trees in maize fields by season, participant type $\&$ gender

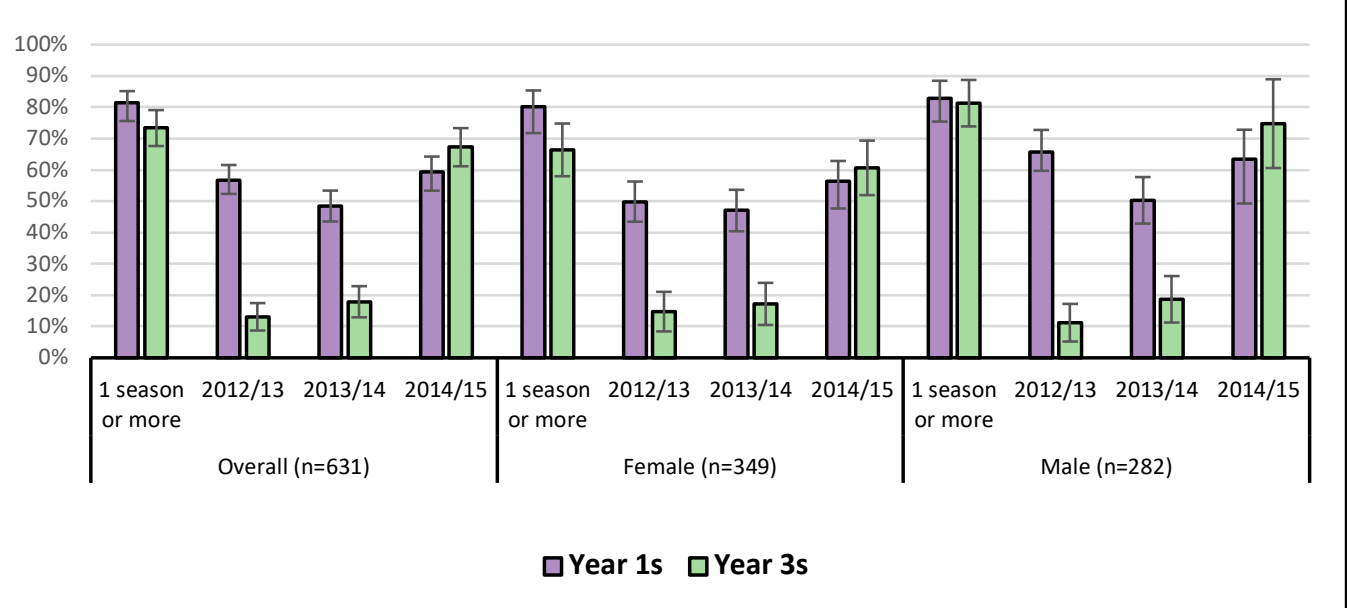

Figure 6 and Table 5 further disaggregate the data by fertilizer tree type, specifically for the Years 1 and 2. Tephrosia vogelii and pigeon pea were the most commonly intercropped tree species among the Year 1 participants, followed by Gliricidia sepium and Faidherbia albida. It is also noteworthy that pigeon pea was reported to be the most intercropped fertilizer tree among the Year 3 participantsa point that will be discussed further in the presentation of the site-disaggregated results. Moreover, intercropping of other fertilizer tree species in Years 1 and 2 among Year 3 participants was reportedly very modest. Overall, there is considerable evidence that most AFSPII participant farmers attempted to intercrop fertilizer trees at least once. If they had already been doing so, we would not expect to see a large difference between Year 1 and Year 3 participants in Years 1 and 2, but would expect a large jump among Year 3 participants in Year 3 (when they began formal participation in AFSPII).

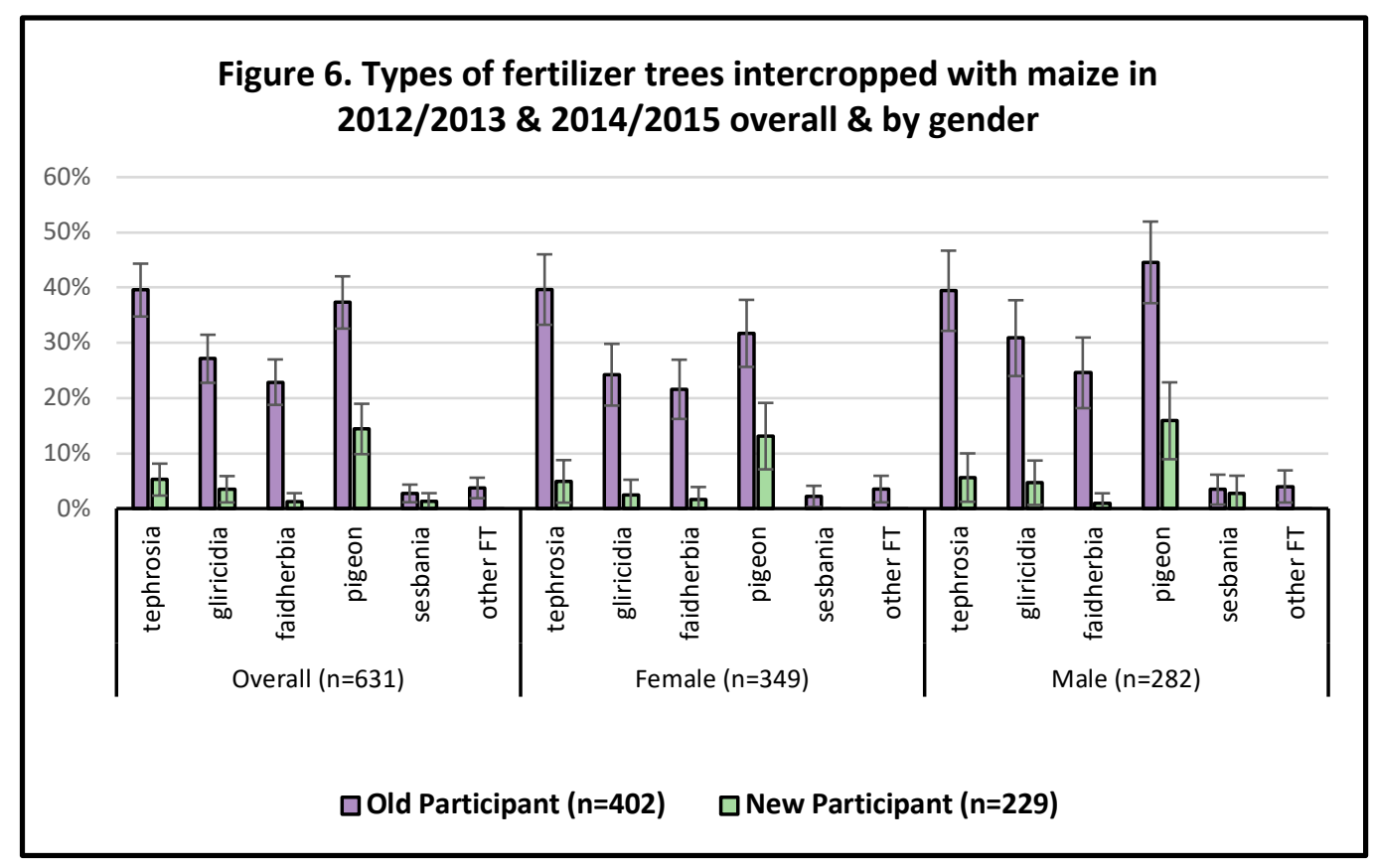


Table 5. Intercropping of maize with fertilizer trees overall and by gender

\begin{tabular}{|c|c|c|c|c|c|c|c|c|c|}
\hline & \multicolumn{3}{|c|}{ Overall } & \multicolumn{3}{|c|}{ Female } & \multicolumn{3}{|c|}{ Male } \\
\hline Variable & $Y 1 s$ & $Y 3 s$ & dif. & $Y 1 s$ & $Y 3 s$ & dif. & $Y 1 s$ & $Y 3 s$ & dif. \\
\hline \multicolumn{10}{|c|}{ Intercropping of fertilizer trees } \\
\hline Any time in last three years & 0.81 & 0.73 & $\begin{array}{c}0.080 * * \\
(2.34)\end{array}$ & 0.80 & 0.66 & $\begin{array}{c}0.14 * * * \\
(2.85)\end{array}$ & 0.83 & 0.81 & $\begin{array}{l}0.015 \\
(0.33)\end{array}$ \\
\hline $2012 / 2013$ farming season & 0.57 & 0.13 & $\begin{array}{c}0.44 * * * \\
(10.7)\end{array}$ & 0.50 & 0.15 & $\begin{array}{c}0.35 * * * \\
(6.44)\end{array}$ & 0.66 & 0.11 & $\begin{array}{c}0.54 * * * \\
(8.93)\end{array}$ \\
\hline $2013 / 2014$ farming season & 0.49 & 0.18 & $\begin{array}{c}0.31 * * * \\
(7.64)\end{array}$ & 0.47 & 0.17 & $\begin{array}{c}0.30 * * * \\
(5.53)\end{array}$ & 0.50 & 0.19 & $\begin{array}{c}0.32 * * * \\
(5.30)\end{array}$ \\
\hline $2014 / 2015$ farming season & 0.59 & 0.67 & $\begin{array}{c}-0.078 * \\
(-1.94)\end{array}$ & 0.56 & 0.61 & $\begin{array}{l}-0.043 \\
(-0.77)\end{array}$ & 0.63 & 0.75 & $\begin{array}{c}-0.11 * * \\
(-1.98)\end{array}$ \\
\hline \multicolumn{10}{|l|}{$\begin{array}{l}\text { Type of fertilizer trees } \\
\text { intercropped } \\
\text { in } 2012 / 2013 \text { and } 2013 / 2014 \\
\text { seasons }\end{array}$} \\
\hline Tephrosia & 0.40 & 0.05 & $\begin{array}{c}0.34 * * * \\
(9.32)\end{array}$ & 0.40 & 0.05 & $\begin{array}{c}0.35 * * * \\
(6.93)\end{array}$ & 0.39 & 0.06 & $\begin{array}{c}0.34 * * * \\
(6.24)\end{array}$ \\
\hline Gliricidia & 0.27 & 0.03 & $\begin{array}{c}0.24 * * * \\
(7.34)\end{array}$ & 0.24 & 0.02 & $\begin{array}{c}0.22 * * * \\
(5.21)\end{array}$ & 0.31 & 0.05 & $\begin{array}{c}0.26^{* * *} * \\
(5.25)\end{array}$ \\
\hline Faidherbia & 0.23 & 0.01 & $\begin{array}{c}0.22 * * * \\
(7.29)\end{array}$ & 0.22 & 0.02 & $\begin{array}{c}0.20 * * * \\
(5.03)\end{array}$ & 0.25 & 0.01 & $\begin{array}{c}0.24 * * * \\
(5.31)\end{array}$ \\
\hline Pigeon pea & 0.37 & 0.14 & $\begin{array}{c}0.23 * * * \\
(6.10)\end{array}$ & 0.32 & 0.13 & $\begin{array}{c}0.19 * * * \\
(3.82)\end{array}$ & 0.45 & 0.16 & $\begin{array}{c}0.29 * * * \\
(4.95)\end{array}$ \\
\hline Sesbania & 0.03 & 0.01 & $\begin{array}{c}0.014 \\
(1.17)\end{array}$ & 0.02 & 0.00 & $\begin{array}{c}0.022 * \\
(1.65)\end{array}$ & 0.03 & 0.03 & $\begin{array}{c}0.0062 \\
(0.29)\end{array}$ \\
\hline Other fertilizer tree & 0.04 & 0.00 & $\begin{array}{c}0.037 * * * \\
(2.96)\end{array}$ & 0.04 & 0.00 & $\begin{array}{c}0.035 * * \\
(2.10)\end{array}$ & 0.04 & 0.00 & $\begin{array}{c}0.040 * * \\
(2.09)\end{array}$ \\
\hline Observations & 402 & 229 & 631 & 227 & 122 & 349 & 175 & 107 & 282 \\
\hline
\end{tabular}

$z$ statistics in parentheses

$* \mathrm{p}<0.1, * * \mathrm{p}<0.05, * * * \mathrm{p}<0.01$

Figure 7, Figure 8, and Table 6 present site- and district-specific results. Significant inter-site variation occurred over the three seasons among Year 1 participants. In Mzimba for example, there was a drop after Year 1 in fertilizer tree intercropping that did not fully recover by Year 3, whereas in Thyolo, a higher percentage of Year 1 participants attempted to intercrop fertilizer trees in Year 3 than in Years 1 or 2 . While recognizing the limitations posed by the small sample size, consistent fertilizer tree intercropping appears to have been erratic at the Dedza upland site.

Figure 7. Reported intercropping of fertilizer trees in maize fields by season, participant type $\&$ site

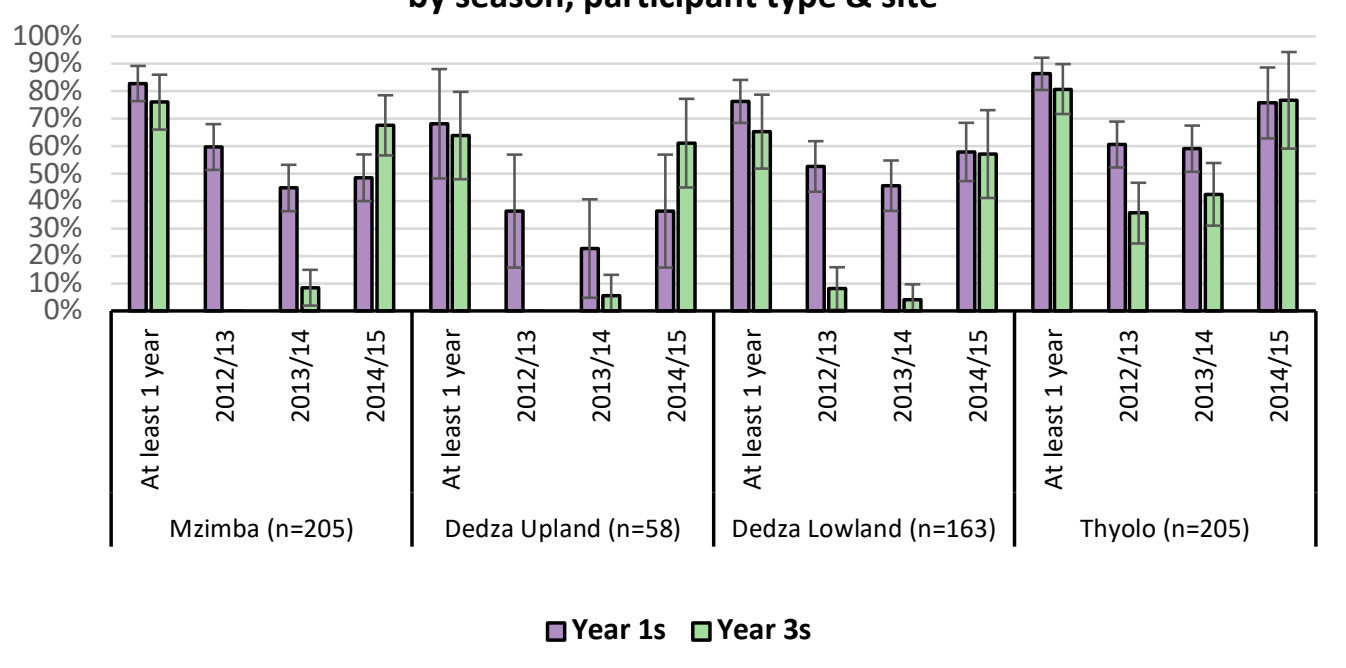


Figure 8 and Table 6 present district-specifc results by fertilizer tree type. The results for Thyolo are particulalry noteworty given that a high percentage of Year 3 participants reported intercropping pigeon pea with maize in both Years 1 and 2 (i.e. before formal participation in AFSPII). Given that such intercropping is a traditional practice in this area (as explained in subsection 3.2), this explains why a higher percentage of Year 3 participants in Tyolo District reported having intercropped prior to commencing their participation in AFSPII than in Dedza and Mzimba.

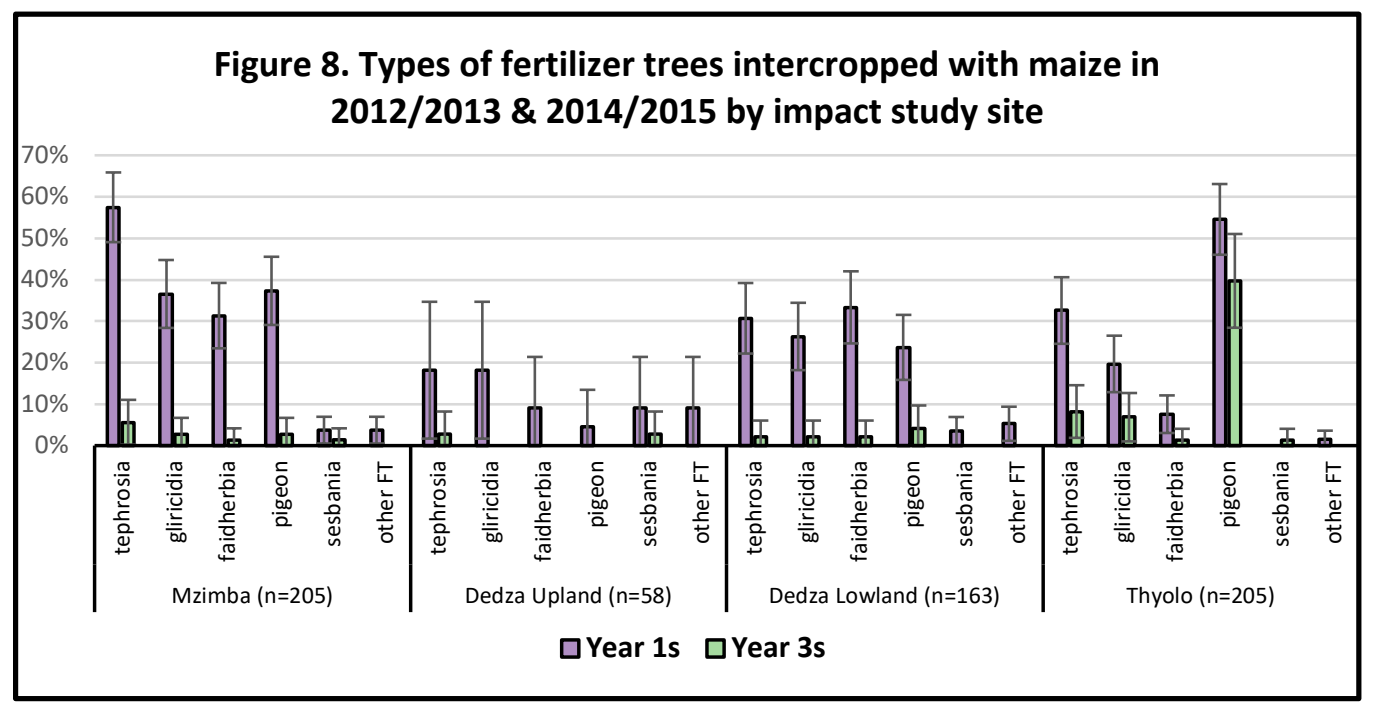

Table 6. Intercropping of maize with fertilizer trees by district

\begin{tabular}{|c|c|c|c|c|c|c|c|c|c|}
\hline & \multicolumn{3}{|c|}{ Mzimba } & \multicolumn{3}{|c|}{ Dedza } & \multicolumn{3}{|c|}{ Thyolo } \\
\hline Variable & $\begin{array}{c}\text { Year } \\
1 \\
\end{array}$ & Year 3 & $\begin{array}{c}\text { differenc } \\
e\end{array}$ & Year 1 & Year 3 & $\begin{array}{c}\text { differenc } \\
e\end{array}$ & Year 1 & Year 3 & $\begin{array}{c}\text { differenc } \\
e\end{array}$ \\
\hline \multicolumn{10}{|c|}{ Intercropping of fertilizer trees } \\
\hline Any time in last three years & 0.83 & 0.76 & $\begin{array}{l}0.068 \\
(1.17)\end{array}$ & 0.75 & 0.65 & $\begin{array}{c}0.10 \\
(1.64)\end{array}$ & 0.86 & 0.81 & $\begin{array}{l}0.055 \\
(1.05)\end{array}$ \\
\hline $2012 / 2013$ farming season & 0.60 & 0.00 & $\begin{array}{c}0.60 * * * \\
(8.34)\end{array}$ & 0.50 & 0.05 & $\begin{array}{c}0.45^{* * *} \\
(6.99)\end{array}$ & 0.61 & 0.36 & $\begin{array}{c}0.25 * * * \\
(3.43)\end{array}$ \\
\hline 2013/2014 farming season & 0.45 & 0.08 & $\begin{array}{c}0.36 * * * \\
(5.30)\end{array}$ & 0.42 & 0.05 & $\begin{array}{c}0.37 * * * \\
(6.02)\end{array}$ & 0.59 & 0.42 & $\begin{array}{c}0.17 * * \\
(2.28)\end{array}$ \\
\hline 2014/2015 farming season & 0.49 & 0.68 & $\begin{array}{c}-0.19 * * * \\
(-2.62)\end{array}$ & 0.54 & 0.59 & $\begin{array}{l}-0.044 \\
(-0.64)\end{array}$ & 0.76 & 0.77 & $\begin{array}{c}-0.0095 \\
(-0.15)\end{array}$ \\
\hline \multicolumn{10}{|l|}{$\begin{array}{l}\text { Type of fertilizer trees } \\
\text { intercropped } \\
\text { in } 2012 / 2013 \text { and } 2013 / 2014 \\
\text { seasons }\end{array}$} \\
\hline Tephrosia & 0.57 & 0.06 & $\begin{array}{c}0.52 * * * \\
(7.22)\end{array}$ & 0.29 & 0.02 & $\begin{array}{c}0.26 * * * \\
(4.90)\end{array}$ & 0.33 & 0.08 & $\begin{array}{c}0.24 * * * \\
(3.92)\end{array}$ \\
\hline Gliricidia & 0.37 & 0.03 & $\begin{array}{c}0.34 * * * \\
(5.32)\end{array}$ & 0.25 & 0.01 & $\begin{array}{c}0.24 * * * \\
(4.72)\end{array}$ & 0.20 & 0.07 & $\begin{array}{c}0.13^{* *} \\
(2.46)\end{array}$ \\
\hline Faidherbia & 0.31 & 0.01 & $\begin{array}{c}0.30 * * * \\
(5.01)\end{array}$ & 0.29 & 0.01 & $\begin{array}{c}0.28 * * * \\
(5.25)\end{array}$ & 0.08 & 0.01 & $\begin{array}{c}0.062^{*} \\
(1.89)\end{array}$ \\
\hline Pigeon pea & 0.37 & 0.03 & $\begin{array}{c}0.34 * * * \\
(5.40)\end{array}$ & 0.21 & 0.02 & $\begin{array}{c}0.18 * * * \\
(3.85)\end{array}$ & 0.55 & 0.40 & $\begin{array}{c}0.15 * * \\
(2.03)\end{array}$ \\
\hline Sesbania & 0.04 & 0.01 & $\begin{array}{c}0.023 \\
(0.94)\end{array}$ & 0.04 & 0.01 & $\begin{array}{l}0.032 \\
(1.34)\end{array}$ & 0.00 & 0.01 & $\begin{array}{l}-0.014 \\
(-1.35)\end{array}$ \\
\hline Other fertilizer tree & 0.04 & 0.00 & $\begin{array}{c}0.037^{*} \\
(1.65)\end{array}$ & 0.06 & 0.00 & $\begin{array}{c}0.059 * * \\
(2.28)\end{array}$ & 0.02 & 0.00 & $\begin{array}{l}0.015 \\
(1.06)\end{array}$ \\
\hline Observations & 134 & 71 & 205 & 136 & 85 & 221 & 132 & 73 & 205 \\
\hline
\end{tabular}

$z$ statistics in parentheses

$* \mathrm{p}<0.1, * * \mathrm{p}<0.05, * * * \mathrm{p}<0.01$ 


\subsubsection{Maturation of intercropped fertilizer trees}

Once planted within maize fields, the next step along the causal chain was for the fertilizer trees to successfully mature. Interviewed participants who reported intercropping fertilizer trees in their maize fields were asked how well the trees had matured, and were given three response options: (i) well: most survived and grew as expected; (ii) mixed: some grew well while others did not; and (iii) not well. Figure 9 and Tables 7 and 8 present the results. About half of those who reported intercropping fertilized trees said that they matured well in both years, with little variation by gender but some by district. Maturation success was highest in Thyolo District and lowest in Dedza in both years. For reasons already explained, it is possible that the overall number of participants who attempted to intercrop the promoted fertilizer trees may have been higher than indicated by the data, and that the percentages falling into the "not well" group may be higher than recorded here. This would push the percentages of those in other two groups downwards.

Table 7. Maturation of fertilizer trees overall and by gender

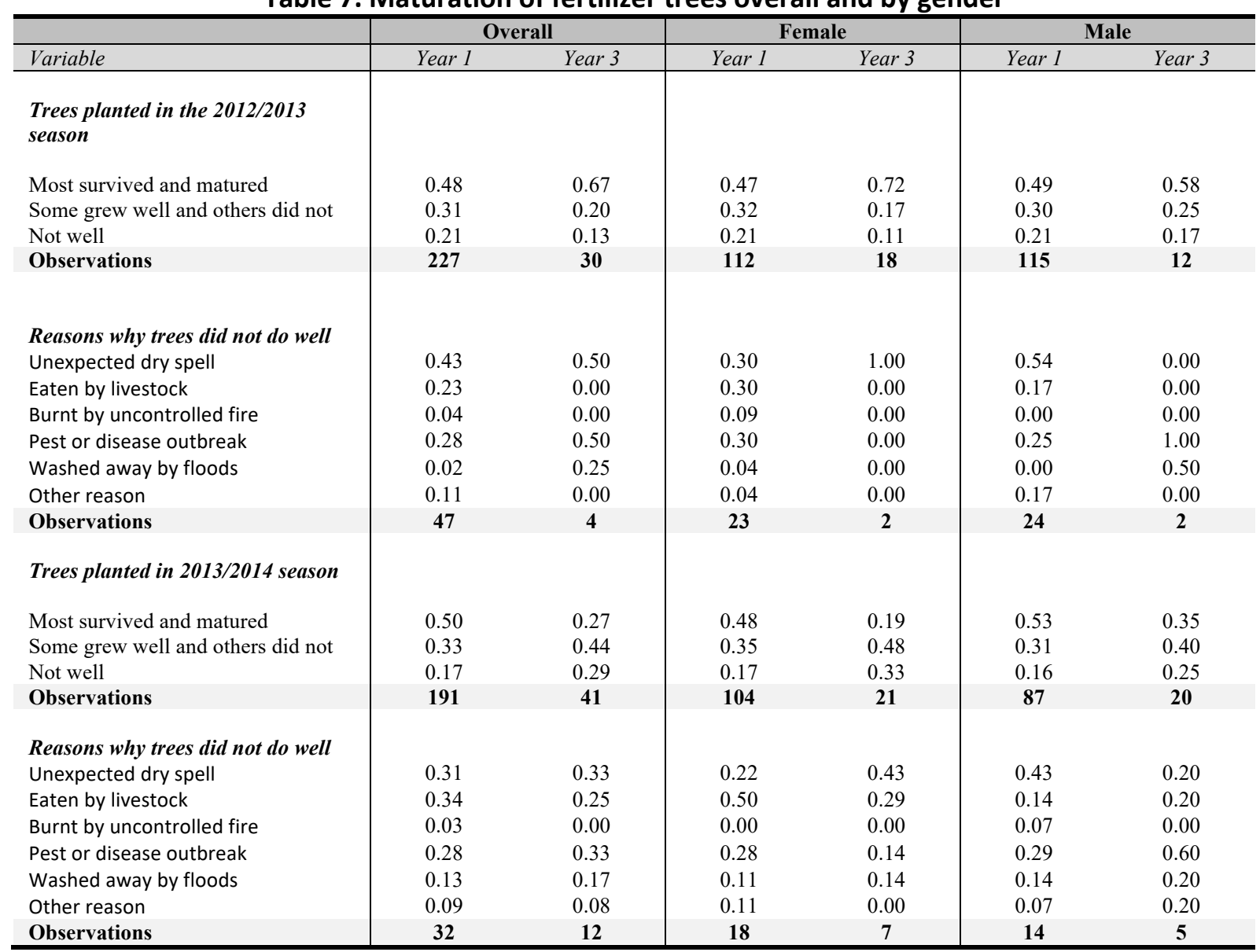

During our scoping mission and the study preparation process, we hypothesized that the percentage of participants falling into the "not well" group would be higher than Figure 9 and Table 7 suggest. Our plan was to identify reasons why the intercropped trees did not mature well, with the hope that some could be considered as quasi-random, thereby enabling instrumental variable analysis (Sovey and Green 2011). If some Year 1 participants' trees matured well and others did not for reasons that could be considered random (e.g. a goat ate all the seedlings), the aim was to compare these two groups in order to estimate the effects of successful fertilizer tree establishment. However: (i) a low proportion of respondents reported unsuccessful maturation; (ii) a relatively small sample size was achieved for the study; and (iii) many of the factors reported (such as unexpected dry spells) are likely correlated with outcome and impact measures, rendering them invalid instruments. We abandoned this analysis. 


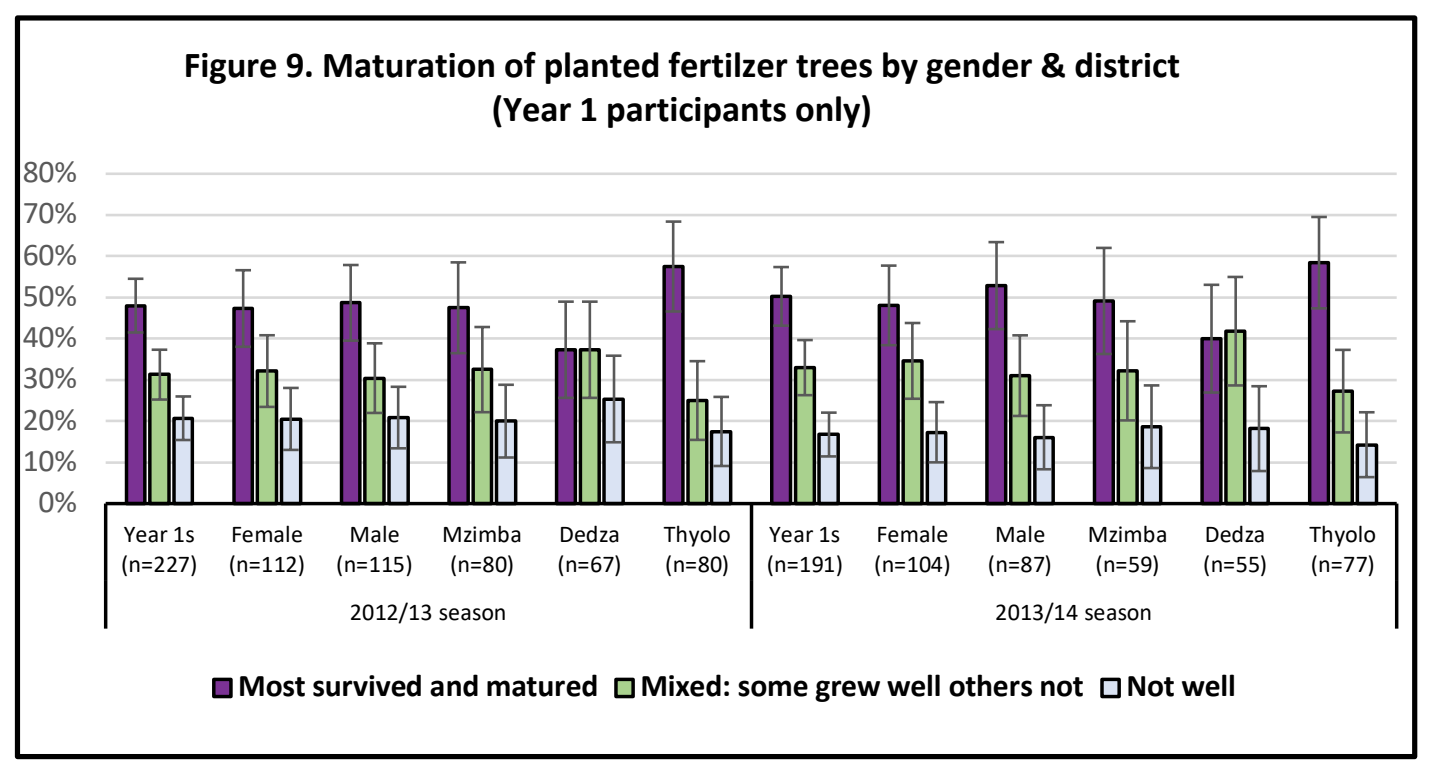

Table 8. Maturation of fertilizer trees by district

\begin{tabular}{|c|c|c|c|c|c|c|}
\hline \multirow[b]{2}{*}{ Variable } & \multicolumn{2}{|c|}{ Mzimba } & \multicolumn{2}{|c|}{ Dedza } & \multicolumn{2}{|c|}{ Thyolo } \\
\hline & Year 1 & Year 3 & Yearl & Year 3 & Yearl & Year 3 \\
\hline \multicolumn{7}{|l|}{ Trees planted in 2012/2013 season } \\
\hline Most survived and matured & 0.47 & -- & 0.37 & 0.75 & 0.57 & 0.65 \\
\hline Some grew well and others did not & 0.33 & -- & 0.37 & 0.25 & 0.25 & 0.19 \\
\hline Not well & 0.20 & -- & 0.25 & 0.00 & 0.17 & 0.15 \\
\hline Observations & 80 & & 67 & 4 & 80 & 26 \\
\hline \multicolumn{7}{|l|}{ Reasons why trees did not do well } \\
\hline Unexpected dry spell & 0.56 & -- & 0.29 & -- & 0.43 & 0.50 \\
\hline Eaten by livestock & 0.31 & -- & 0.35 & -- & 0.00 & 0.00 \\
\hline Burnt by uncontrolled fire & 0.13 & -- & 0.00 & -- & 0.00 & 0.00 \\
\hline Pest or disease outbreak & 0.13 & -- & 0.29 & -- & 0.43 & 0.50 \\
\hline Washed away by floods & 0.00 & -- & 0.00 & -- & 0.07 & 0.25 \\
\hline Other reason & 0.13 & -- & 0.12 & -- & 0.07 & 0.00 \\
\hline Observations & 16 & -- & 17 & -- & 14 & 4 \\
\hline \multicolumn{7}{|l|}{ Trees planted in $2013 / 2014$ season } \\
\hline Most survived and matured & 0.49 & 0.17 & 0.40 & 0.00 & 0.58 & 0.32 \\
\hline Some grew well and others did not & 0.32 & 0.50 & 0.42 & 0.00 & 0.27 & 0.48 \\
\hline Not well & 0.19 & 0.33 & 0.18 & 1.00 & 0.14 & 0.19 \\
\hline Observations & 59 & 6 & 55 & 4 & 77 & 31 \\
\hline \multicolumn{7}{|l|}{ Reasons why trees did not do well } \\
\hline Unexpected dry spell & 0.64 & 1.00 & 0.10 & 0.00 & 0.18 & 0.33 \\
\hline Eaten by livestock & 0.55 & 0.00 & 0.50 & 0.50 & 0.00 & 0.17 \\
\hline Burnt by uncontrolled fire & 0.09 & 0.00 & 0.00 & 0.00 & 0.00 & 0.00 \\
\hline Pest or disease outbreak & 0.09 & 0.00 & 0.30 & 0.00 & 0.45 & 0.67 \\
\hline Washed away by floods & 0.00 & 0.00 & 0.20 & 0.25 & 0.18 & 0.17 \\
\hline Other reason & 0.00 & 0.00 & 0.10 & 0.25 & 0.18 & 0.00 \\
\hline Observations & 11 & 2 & 10 & 4 & 11 & 6 \\
\hline
\end{tabular}

Reviewing the reasons for poor tree establishment, as presented in tables 7 and 8 , is noteworthy. The most commonly cited reasons were unexpected dry spells, livestock foraging and pest or disease outbreaks. It is interesting that women were more likely than men to cite problems with the uncontrolled grazing of livestock in both Years 1 and 3. There is also considerable variation among the three districts. In Thyolo, for instance, livestock was not cited as a reason, in line with our 
understanding that goats are commonly tethered in this district due to the longstanding practice of intercropping pigeon pea and maize.

The in-depth follow-up interviews confirmed that poor establishment of trees was a key challenge: 18 out of 40 farmers referred to issues around poor rainfall, termites or excessive pruning as the cause of their tree seedlings drying out. Of these 18, 10 were female farmers and eight of these reported that they had not received any benefits from the programme, given that their trees dried out (mainly due to dry spells). Four of their male counterparts mentioned the same problem. Consistent with the quantitative data, more farmers in Dedza District than in others referred to challenges with tree establishment in the qualitative follow-up interviews (10 out of the 15 interviewed). Poor rainfall was most frequently reported as the main cause. Finally, only six farmers of the 40 interviewed overall in the follow-up exercise mentioned grazing as a challenge-five of them women from Dedza and Mzimba districts.

\subsubsection{Incorporation of biomass from intercropped fertilizer trees}

Once successfully established and mature, the leafy biomass of the intercropped fertilizer trees was to be physically incorporated into the soil (see subsection 3.2), except for Faidherbia albida. ${ }^{13}$ In order to understand the extent to which incorporation took place, the interviewed participants were asked whether they had incorporated biomass from maize stover, groundnut forage, fertilizer tree leaves or anything else prior to maize seed planting in the 2014/2015 farming season (Year 3 of AFSPII). The results are presented in Table 9. While the incorporation of biomass from any source in 2014/2015 was reported to be $79 \%$ among Year 1 participants, less than one third reported incorporating biomass specifically from fertilizer trees. This figure was only about one quarter in the previous 2013/2014 farming season (Year 2 of AFSPII).

We found it particularly surprising that similar percentages of Year 1 and Year 3 participants reported similar levels of biomass incorporation in the 2014/2015 farming season. The Year 3 participants would have been provided with tree seeds or seedlings prior to land preparation in late 2014. These would have been matured and ready for incorporation during the 2015/2016 farming season. One possible explanation is that some respondents misunderstood the question. However, we would find this surprising, given that the question, "Before planting, did you incorporate any of the following..." was asked in relation to the maize they cultivated during the previous farming season. This issue will be re-visited after explaining our efforts to measure the quantity of biomass that was actually incorporated.

As stated in subsection 3.2, the programme team already knew from previous research on the promoted fertilizer trees that a large quantity of leafy biomass needed to be both generated and incorporated into the soil (or simply fall onto soil in the case of Faidherbia albida) in order to produce the expected soil fertility. Therefore, having a simple binary measure of whether participating farmers incorporated fertilizer tree biomass or not would have been insufficient. Given feasibility considerations, we needed to identify a practical yet informative way of estimating biomass incorporation. While cruder than conducting actual field-based measurements, the decision was made to use pictures. If the interviewee reported having undertaken fertilizer tree biomass incorporation,

\footnotetext{
${ }^{13}$ Once transplanted from nurseries into the field, Faidherbia albida saplings take anywhere from seven to 15 years to mature. Thereafter, the leaves they shed can directly decompose into the soil without the need for physical incorporation (Spevacek 2011). Consequently, the AFSPII participants who attempted to implement this fertilizer tree technology could only be expected to experience the expected benefits several years after programme closure. While 15\% of AFSPII participants intercropped Faidherbia albida saplings (23\% of Year 1 participants), only $2 \%$ ( $3 \%$ of Year 1 participants) did so exclusively for this particular fertilizer tree species. The majority complemented Faidherbia albida intercropping with one or more of the other promoted fertilizer tree species.
} 
they were shown the picture associated with the fertilizer tree species in question and asked: "Out of the following pictures, please select the one that most closely resembles how the [fertilizer tree species] trees looked like prior to incorporation." An example for Tephrosia vogelii is presented in Figure 10. Similar pictures were used for other tree species. This enabled a rapid classification of the approximate density of incorporated biomass, which was complemented by questioning respondents regarding the characteristics of the field where incorporation took place.

Figure 10: Example of photos shown to respondents to gauge the level of biomass incorporation (Tephrosia)

\begin{tabular}{|l|l|l|}
\hline High biomass incorporation & Moderate biomass incorporation & Low biomass incorporation \\
\hline & & \\
& & \\
& &
\end{tabular}

Figure 11 compares the Year 1 and Year 3 participants on: (i) whether they incorporated fertilizer tree biomass in both the 2013/2014 and 2014/2015 farming seasons; (ii) if so, whether the density of the biomass was significant or at least moderate (e.g. either picture A or B in Figure 10); and (iii) whether incorporation took place on more than half of their primary maize fields. These amounts are low for both groups, but are significantly lower for Year 3 participants. Only 14\% of those in Year 1 managed to incorporate a moderate to significant quantity of biomass prior to maize planting in both years on more than half of their primary maize fields. ${ }^{14}$ While gender-related differences were observed, it is the district-specific differences that stand out. In both Mzimba and Dedza districts, there were large and statistically significant differences between the Year 1 and Year 3 participants. While there were differences between these two groups in Thyolo district, these were not statistically significant despite the fact that Year 1 participants in this district outperformed their counterparts in the other two districts. Tables A21 and A22 in Annex 2 present further details, including the results of statistical tests between the Year 1 and 3 participants.

Figure 12 presents comparable statistics for each farming season. For both Year 1 and Year 3, and across the three districts, we saw an increase in efforts to incorporate fertilizer tree biomass prior to maize planting from the 2013/2014 to the 2014/2015 farming seasons. However, even in the 2014/2015 season, Year 1 participants were more likely to incorporate moderate to significant biomass, except in Thyolo district where the likelihood was about the same. That said, this comparison between two farming seasons may indicate programme spill-over effects within the villages, particularly with respect to behaviour change among Year 3 participants even before their formal participation in AFSPII.

\footnotetext{
${ }^{14}$ This results changes by only about 0.5 of a percentage point if we exclude Year 1 participants who reported only intercropping Faidherbia albida. One could argue that these participants should be excluded from the analysis, given that: (i) the physical incorporation of its leaves into the soil is not a requirement for this particular technology; and (ii) the trees were still maturing at the time of data collection, so no fertilizer tree biomass would be expected to be generated from them.
} 

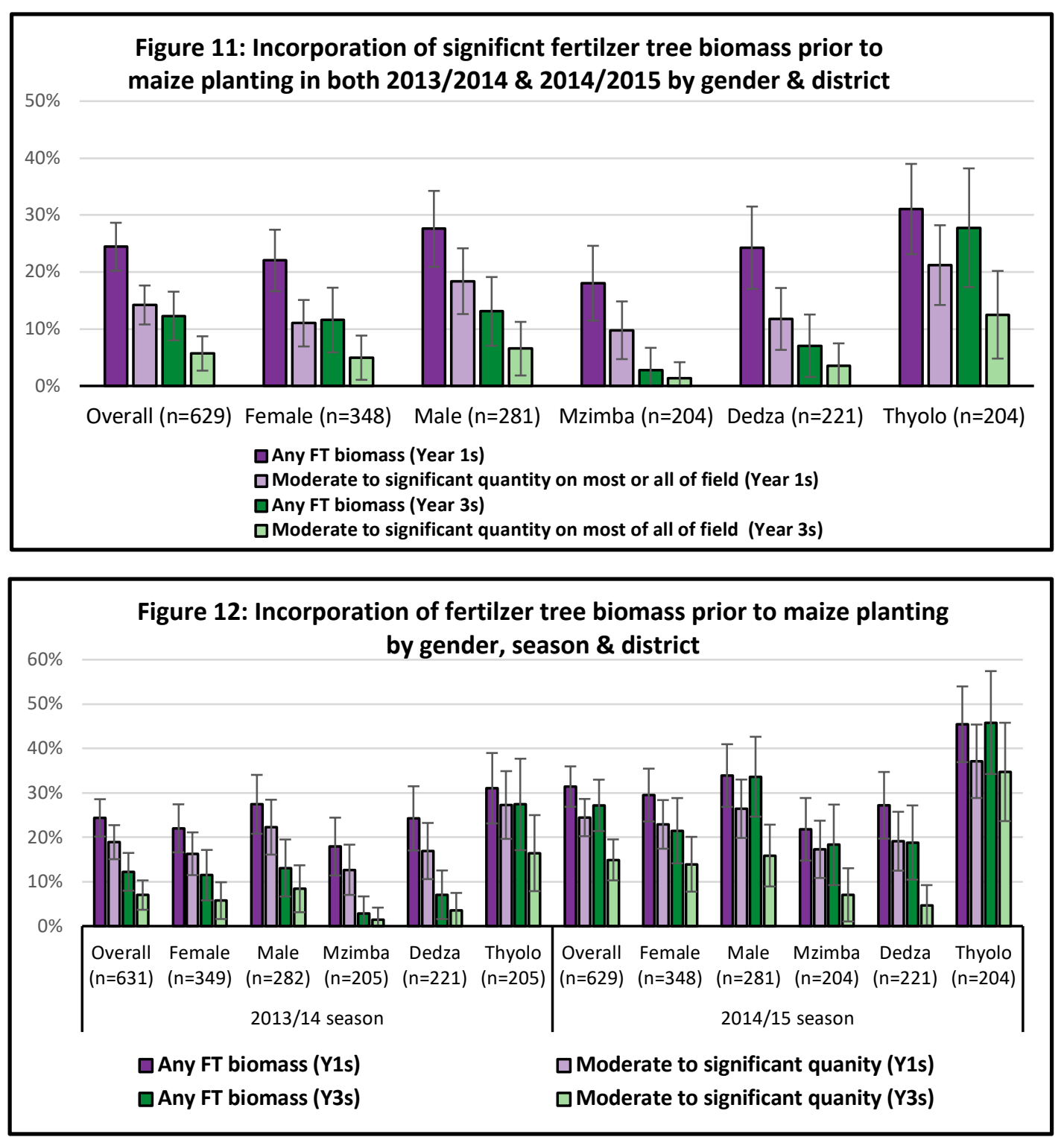

While those who did not incorporate fertilizer tree biomass were not directly asked why they did not do so, we were able to ascertain the main reasons from the dataset. The results are presented in Table 9 and in Table A23 in Annex 2, which includes a breakdown by district. The most common reason was that participants did not intercrop fertilizer trees during the previous season. This was especially the case for the Year 3 participants. Interestingly, poor maturation of intercropped fertilizer trees was relatively rarely given as a reason. However, as discussed in subsections 5.2.2 and 5.2.3, some participants who reported that they did not intercrop actually attempted to do so, but the seedlings either dried up soon after or were eaten by goats. As a result, these percentages may actually be higher than those presented in Table 9. 
Table 9. Reasons for not incorporating fertilizer tree biomass prior to maize planting

\begin{tabular}{|c|c|c|c|c|c|c|c|c|c|}
\hline \multirow[b]{2}{*}{ Variable } & \multicolumn{3}{|c|}{ Overall } & \multicolumn{3}{|c|}{ Female } & \multicolumn{3}{|c|}{ Male } \\
\hline & Year 1 & Year 3 & difference & Year 1 & Year 3 & difference & Year 1 & Year 3 & difference \\
\hline \multicolumn{10}{|l|}{ 2014/2015 farming season } \\
\hline $\begin{array}{l}\text { Did not intercrop fertilizer trees in } \\
2013 / 14\end{array}$ & 0.64 & 0.90 & $\begin{array}{c}-0.27 * * * \\
(-6.18)\end{array}$ & 0.65 & 0.94 & $\begin{array}{l}-0.29 * * * \\
(-5.20)\end{array}$ & 0.62 & 0.86 & $\begin{array}{c}-0.24 * * * \\
(-3.49)\end{array}$ \\
\hline $\begin{array}{l}\text { Intercropped but trees did not } \\
\text { mature well }\end{array}$ & 0.08 & 0.04 & $\begin{array}{c}0.047^{*} \\
(1.95)\end{array}$ & 0.07 & 0.04 & $\begin{array}{l}0.033 \\
(1.07)\end{array}$ & 0.09 & 0.03 & $\begin{array}{c}0.067^{*} \\
(1.74)\end{array}$ \\
\hline $\begin{array}{l}\text { Intercropped with moderate to } \\
\text { good results but no incorporation }\end{array}$ & 0.27 & 0.06 & $\begin{array}{l}0.21 * * * \\
(5.42)\end{array}$ & 0.26 & 0.02 & $\begin{array}{c}0.24 * * * \\
(4.88)\end{array}$ & 0.28 & 0.11 & $\begin{array}{c}0.17 * * * \\
(2.76)\end{array}$ \\
\hline Observations & 276 & 167 & 443 & 160 & 96 & 256 & 116 & 71 & 187 \\
\hline \multicolumn{10}{|l|}{$2013 / 2014$ farming season } \\
\hline $\begin{array}{l}\text { Did not intercrop fertilizer trees in } \\
2012 / 2013\end{array}$ & 0.53 & 0.93 & $\begin{array}{c}-0.40 * * * \\
(-9.52)\end{array}$ & 0.59 & 0.93 & $\begin{array}{c}-0.34 * * * \\
(-6.14)\end{array}$ & 0.45 & 0.94 & $\begin{array}{c}-0.49 * * * \\
(-7.50)\end{array}$ \\
\hline $\begin{array}{l}\text { Intercropped but trees did not } \\
\text { mature well }\end{array}$ & 0.13 & 0.00 & $\begin{array}{c}0.12 * * * \\
(4.95)\end{array}$ & 0.10 & 0.00 & $\begin{array}{c}0.096 * * * \\
(3.32)\end{array}$ & 0.17 & 0.01 & $\begin{array}{c}0.15^{* * *} \\
(3.78)\end{array}$ \\
\hline $\begin{array}{l}\text { Intercropped with moderate to } \\
\text { good results, but no incorporation }\end{array}$ & 0.34 & 0.06 & $\begin{array}{c}0.28 * * * \\
(7.23)\end{array}$ & 0.31 & 0.07 & $\begin{array}{c}0.24 * * * \\
(4.67)\end{array}$ & 0.39 & 0.05 & $\begin{array}{c}0.33 * * * \\
(5.65)\end{array}$ \\
\hline Observations & 304 & 201 & 505 & 177 & 108 & 285 & 127 & 93 & 220 \\
\hline
\end{tabular}

$z$ statistics in parentheses

$* \mathrm{p}<0.1, * * \mathrm{p}<0.05, * * * \mathrm{p}<0.01$

A high number of Year 1 participants reported that the fertilizer trees they had incorporated matured well and generated moderate to high leafy biomass, yet they did not incorporate this biomass prior to planting maize during the subsequent farming season. During the qualitative follow-up, we specifically classified this category of participants as "non-incorporators" and purposively selected nine of them for interviews. Three of these Year 1 participants stated that they did not incorporate the biomass because either they missed the time for doing so or did not understand that this was supposed to be done. Another three in this group reported that they thought that they had not generated enough leafy biomass to warrant incorporation. The remaining three explained that they had in fact managed to incorporate sufficient fertilizer tree biomass and obtained good results.

We also quantitatively explored the extent to which Year 1 participants who managed to successfully incorporate significant or moderate fertilizer tree biomass in both Year 2 and Year 3 on more than half of their primary maize fields differed from those who did not. Table 10 presents both the raw and net data on site differences. Some clear differences stand out. "Successful adopters": (i) were less likely to be female and more likely to be heads of households; (ii) had been wealthier at baseline; (iii) had more years of education; (iv) came from households with more productive adults; (v) had an official role in the community; and (vi) also kept livestock. Given the relative complexity of the promoted practices, these findings were not surprising. However, they may reveal the need to provide participants who lack capacity with tailored and intensive support.

Findings from the qualitative follow-up interviews also indicate that the level of support varied among participating farmers, and there is evidence that these differences effected their consistent practice of the technology. We asked the farmers about support they received both from governmental and non-governmental organizations, and specifically about the AFSPII programme. In almost all cases, they reported that they had received input support - most commonly in the form of fertilizer, fertilizer subsidies, seeds or seedlings. In a few cases, farmers also mentioned receiving treadle pumps for irrigation. 
Table 10. Differences between successful and unsuccessful adopters

\begin{tabular}{|c|c|c|c|c|c|c|}
\hline & $\begin{array}{c}\text { Adopter } \\
\text { mean }\end{array}$ & $\begin{array}{c}\text { Non-adopter } \\
\text { mean }\end{array}$ & $\begin{array}{c}\text { Raw } \\
\text { Difference }\end{array}$ & $t$-statistic & $\begin{array}{c}\text { Difference net } \\
\text { of site }\end{array}$ & $t$-statistic \\
\hline Female participant & 0.44 & 0.60 & $-0.15 * *$ & $(-2.09)$ & $-0.43^{* *}$ & $(-2.36)$ \\
\hline Other religion & 0.00 & 0.01 & $-0.012 * *$ & $(-2.01)$ & 0 & (.) \\
\hline Chewa & 0.12 & 0.20 & $-0.084 *$ & $(-1.71)$ & -0.27 & $(-0.83)$ \\
\hline Lomwe & 0.39 & 0.27 & $0.12 *$ & $(1.72)$ & -0.28 & $(-1.06)$ \\
\hline Ngoni & 0.28 & 0.24 & 0.045 & $(0.71)$ & $0.38^{*}$ & (1.78) \\
\hline Respondent is household head & 0.77 & 0.63 & $0.13^{* *}$ & (2.11) & $0.43 * *$ & $(2.14)$ \\
\hline Respondent has technical skills & 0.00 & 0.02 & $-0.020 * * *$ & $(-2.67)$ & 0 & (.) \\
\hline Respondent health okay & 1.00 & 0.97 & $0.032 * * *$ & (3.36) & 0 & (.) \\
\hline Not productive & 0.00 & 0.01 & $-0.015^{* *}$ & $(-2.25)$ & 0 & (.) \\
\hline Casual labourer & 0.00 & 0.01 & $-0.0087^{*}$ & $(-1.74)$ & 0 & (.) \\
\hline Skilled wage worker & 0.00 & 0.01 & $-0.012 * *$ & $(-2.01)$ & 0 & (.) \\
\hline Other occupation & 0.00 & 0.01 & $-0.0087^{*}$ & $(-1.74)$ & 0 & (.) \\
\hline Respondent is literate & 0.81 & 0.65 & $0.16 * * *$ & $(2.82)$ & $0.56 * * *$ & $(2.76)$ \\
\hline Respondent attended school & 0.00 & 0.01 & $-0.012 * *$ & $(-2.01)$ & 0 & (.) \\
\hline Respondent has official role & 0.58 & 0.36 & $0.21 * * *$ & (3.01) & $0.63 * * *$ & (3.35) \\
\hline All adults in household over 59 & 0.02 & 0.07 & $-0.055^{* *}$ & $(-2.46)$ & -0.64 & $(-1.56)$ \\
\hline Household head is 60 or older & 0.14 & 0.26 & $-0.11 * *$ & $(-2.17)$ & $-0.42 *$ & $(-1.92)$ \\
\hline Female literate adult in household & 0.74 & 0.65 & 0.089 & (1.39) & $0.35^{*}$ & $(1.83)$ \\
\hline Household head is literate & 0.82 & 0.73 & $0.10 *$ & $(1.80)$ & $0.39 *$ & $(1.86)$ \\
\hline Household head is productive & 1.00 & 0.99 & $0.0087^{*}$ & (1.74) & 0 & (.) \\
\hline Household involved in farming & 1.00 & 0.99 & $0.0087^{*}$ & (1.74) & 0 & (.) \\
\hline Household rears livestock & 0.82 & 0.57 & $0.25 * * *$ & $(4.46)$ & $0.78 * * *$ & (3.74) \\
\hline Years of education of respondent & 6.02 & 4.99 & $1.03^{*}$ & $(1.90)$ & $1.19 * *$ & $(2.34)$ \\
\hline Number of productive adults in household & 2.63 & 2.36 & $0.27 *$ & (1.89) & $0.30 * *$ & $(2.05)$ \\
\hline Highest years of education of any adult in & 8.40 & 7.34 & & & & \\
\hline household & & & $1.01 * *$ & (2.09) & $1.05 * *$ & $(2.23)$ \\
\hline Household wealth index 2011 (PCA) & 0.58 & 0.37 & $0.21 * * *$ & $(4.24)$ & $0.23 * * *$ & (4.97) \\
\hline Household wealth index 2011 (weighted by & 1.99 & 1.69 & & & & \\
\hline $2015 \mathrm{CE})$ & & & $0.30 * * *$ & (3.58) & $0.35 * * *$ & $(4.43)$ \\
\hline Observations & 57 & 344 & 401 & & 401 & \\
\hline
\end{tabular}

$t$ statistics in parentheses

$* \mathrm{p}<0.1, * * \mathrm{p}<0.05, * * * \mathrm{p}<0.01$

$\mathrm{PCA}=$ principal component analysis; $\mathrm{CE}=$ consumption expenditure

For binary variables, probit regression was used for net of site differences so coefficients are not directly interpretable. only

the $t$-statistics are directly interpretable.

There was far greater diversity in farmers' reported receipt of advisory services. Only 18 out of all 40 farmers interviewed referred to training or extension visits from extension workers or peer farmers, or visits to other farmers' fields to learn from demonstrations. When disaggregating by farmer category, nine out of $13(69 \%)$ successful adopters interviewed received this kind of support. Among those that tried to intercrop but failed (at least initially) to incorporate the biomass, four out of nine $(44 \%)$ referred to such support. In the case of the "non-implementers", only three out of $11(27 \%)$ mentioned receiving training along with one out of six (16\%) of the "dis-adopters". When disaggregating by gender, 12 of the 19 (63\%) male farmers interviewed referred to receiving training and technical support, while only seven of the 21 (33\%) female farmers mentioned this.

These findings suggest that farmers with characteristics positively associated with the successful uptake of the promoted practices were also those who received more technical support. Given the fact that both governmental and non-governmental extension agents often have dual roles in imparting new knowledge and skills on the one hand, and providing material inputs on the other, it is likely that the greater receipt of extension support would have also entailed more opportunities to receive seeds and seedlings - increasing the likelihood of taking up and consistently practicing the promoted fertilizer tree technologies. This is consistent with the widely acknowledged effect that input packages and subsidies have on the uptake of sustainable agricultural practices such as agroforestry (Andersson and D'Souza 2014). 
Another relevant finding from the quantitative survey is that more male than female farmers successfully put into practice the promoted fertilizer tree technologies. During the qualitative follow up exercise, we explored this further, asking farmers about the gender division of labour and decision making regarding planting and management of fertilizer trees. We also elicited their views on the possible reasons why men were more likely to utilize the technology. Most farmers referred to both men and women participating in nursery establishment and management, although watering was more often seen as women's work. Regarding decision making about fertilizer trees, most interviewees stated that this was the domain of the household head. This is consistent with the findings of a previous ICRAF study in Malawi (Meijer et al. 2015), which examined household decision making in relation to agricultural practices including tree planting and management. Indeed, most of the women who reported during the follow-up semi-structured interviews that they independently decided to utilize the promoted fertilizer tree practices were household heads. Several respondents did however refer to making joint decisions with their spouses, and two women living in male-headed households mentioned making independent decisions regarding fertilizer tree management.

The observations above underline how the different priorities and needs of men and women related to their gender roles and interests are relevant in shaping the successful uptake of new technologies, and ultimately the outcomes of agronomic scaling efforts. These gender roles were not explicitly factored into the design and implementation of AFSPII, and therefore insufficient measures were undertaken to generate more gender-equitable results.

\subsection{Other programme components}

While the promotion of fertilizer tree maize intercropping was core to AFSPII, other agroforestry practices were promoted as well, albeit among fewer AFSPII participants. Since we did not attempt to oversample from these sub-groups, the sample sizes obtained from each group are small. Nevertheless, the following three subsections present revealing results on the progress of the programme's other complementary components: grafted fruit trees, woodlot tree species and fodder trees for dairy production.

\subsubsection{Grafted fruit trees}

Figure 13 presents the percentages of AFSPII participants who reported receiving fruit trees from external sources and each reported source. Out of our overall sample, $19 \%$ reported receiving fruit trees, with a bias towards Year 1 and male participants. It is also interesting to note that most participants who received these trees appear to have had understood that they originated from ICRAF.

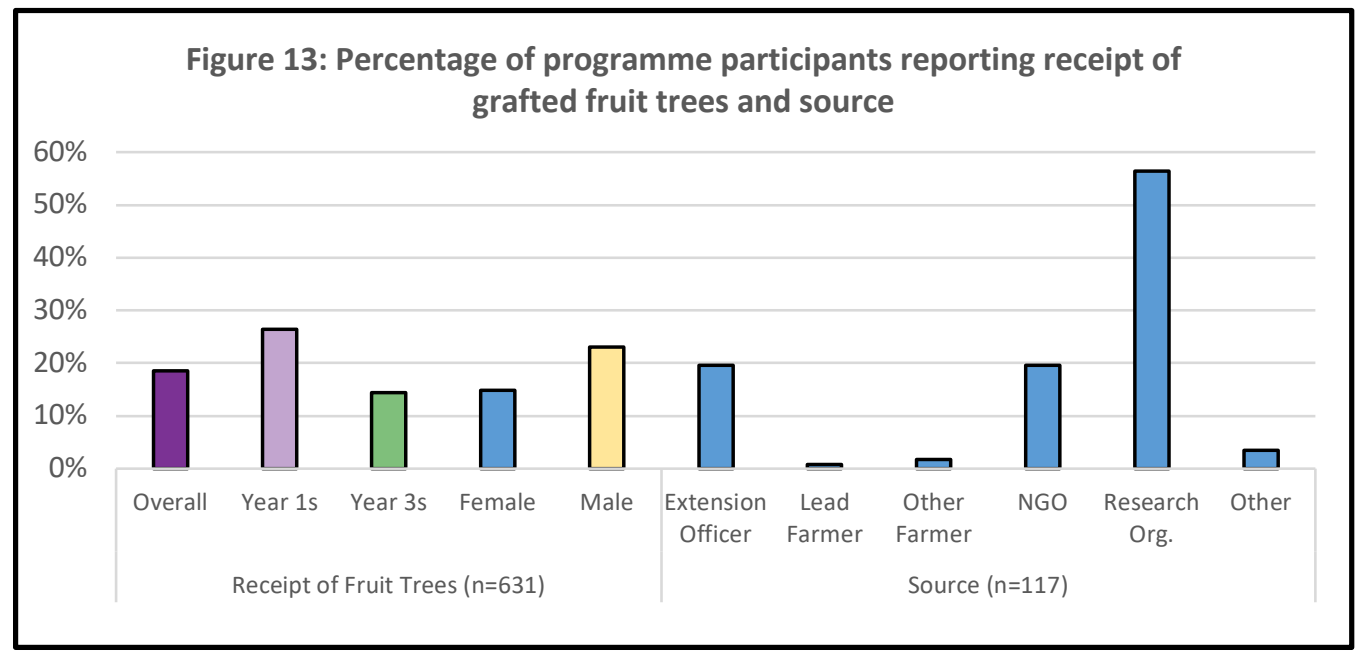


Those who reported receiving the grafted fruit trees were also asked how many seedlings they received, how many they planted and how many had survived. Figure 14 presents the results. Unsurprisingly, a lower number of surviving trees was reported than the number of those received and planted. The programme's target was to have at least 20 surviving trees in each "mother block". It is clear from Figure 14 below that the proportion of fruit tree recipients who realized this targeted is very modest.

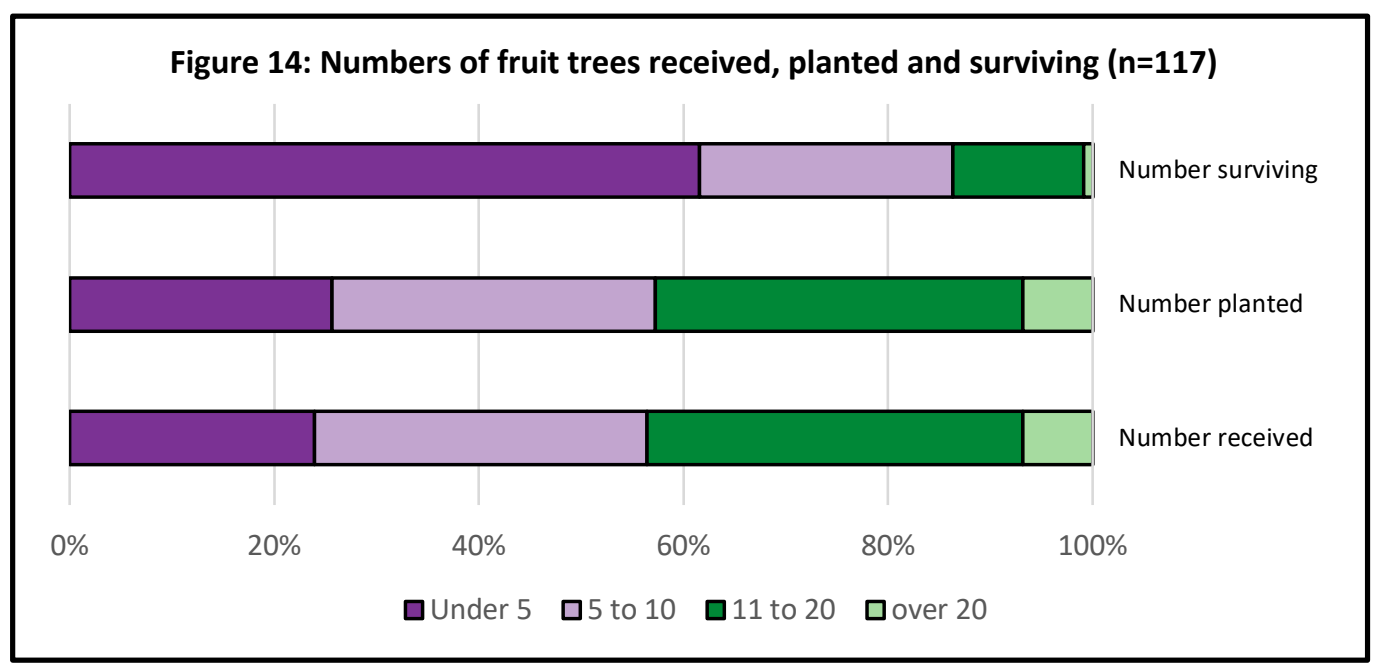

During the qualitative follow-up exercise, 10 of the 40 AFSPII participants interviewed stated that they had also participated in the grafted fruit tree component. When asked which component of the programme was more beneficial for them and their households, most reported that both the fruit trees and the fertilizer trees were beneficial; several added that all trees are beneficial according to their purpose. Interestingly, two farmers (both of them "successful adopters") stated that while they had benefited from the fruit trees, they saw the fertilizer trees as more beneficial.

\subsubsection{Woodlot tree species}

The interviewees were asked if they had participated in a tree nursery focused on woodlot-specific species, and if so, whether they had planted seedlings from this nursery during the previous three years. They were also asked if they had planted any of the timber species promoted by AFSPII and which species. The results are presented in Figure 15 . Over $60 \%$ stated that they had been involved in a woodlot nursery and $30 \%$ reported having planted seedlings from this nursery. Yet only $20 \%$ reported planting any of the promoted timber species, which leads us to suspect that many respondents may have reported their involvement in tree nurseries more generally - possibly including those for Gliricidia sepium and Faidherbia albida.

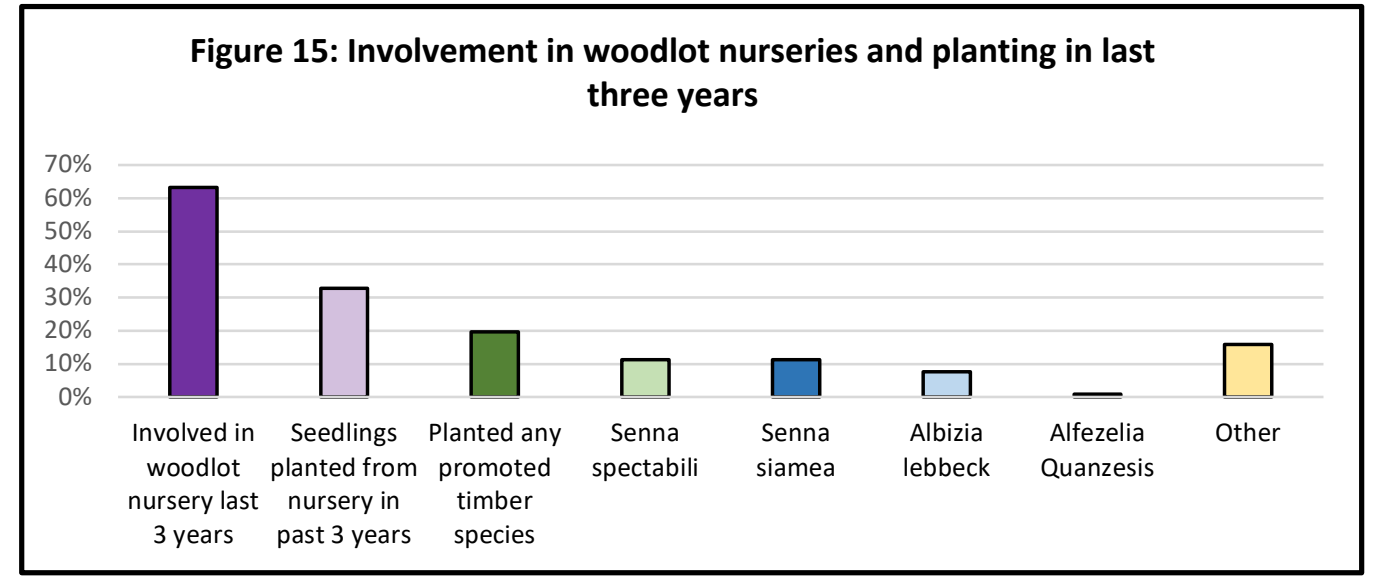


Subsection 2.2 described how each farmer who received woodlot trees was able to successfully establish at least 222. Figure 16 presents the approximate numbers of the promoted woodlot species reported as surviving. As already indicated, most of the participants who benefited from AFSPII's timber-promotion component reported having less than 50 trees of each species.

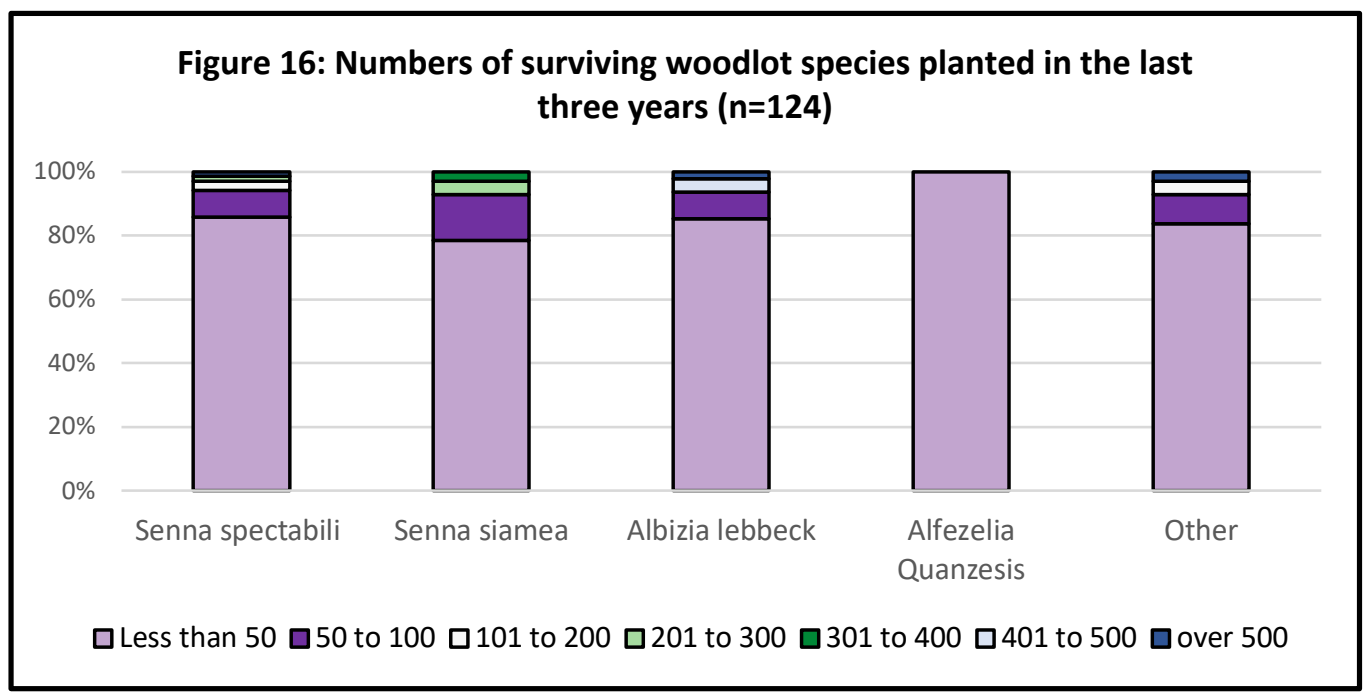

Those who reported planting timber species from nurseries were also asked if they were currently using these trees for any purpose. As indicated in Figure 17, approximately two thirds said no, given that the trees were still immature. However, a small number of households reported that they had made use of the trees for uses such as fuel wood and timber.

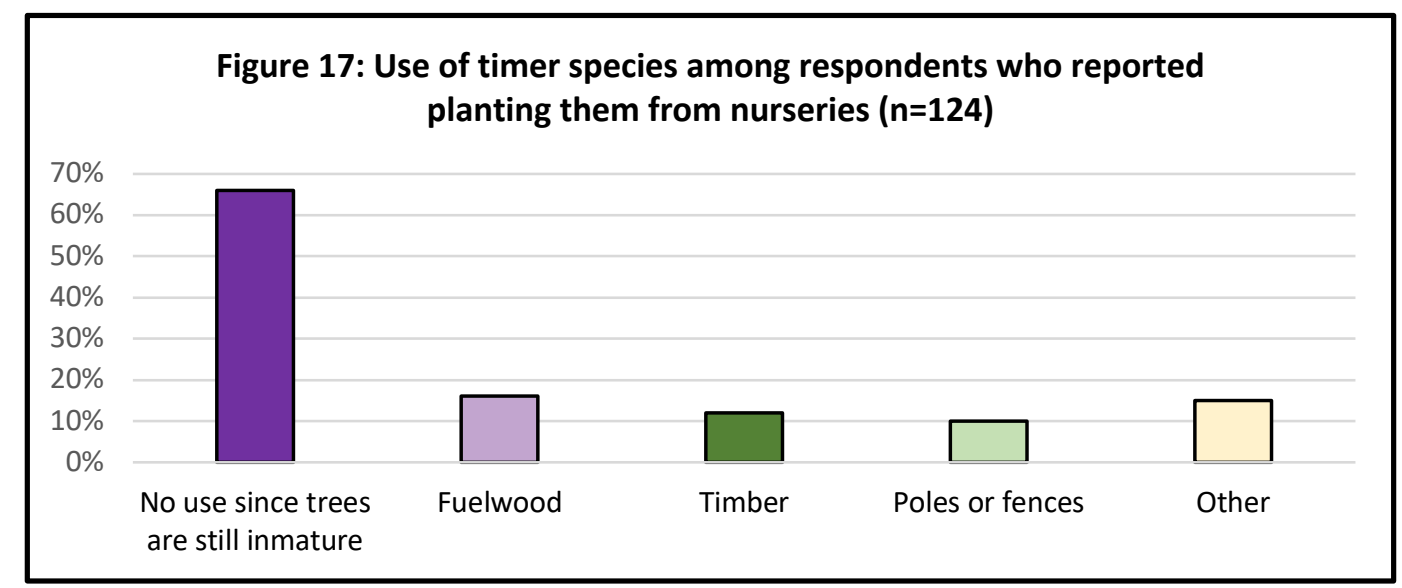

\subsubsection{Promoted tree and shrub fodder for dairy production}

As discussed in subsection 3.2, AFSPII promoted tree and fodder shrubs among the relatively few dairy farmers residing in three out of the 12 EPAs. Figure 18 reveals that less than $7 \%$ of those interviewed reported owning one or more improved dairy cows during the previous three years, and much fewer had participated in a fodder nursery or planted fodder trees from such a nursery. Figure 18 also presents the proportions of households that reported planting particular species of fodder trees and shrubs. 


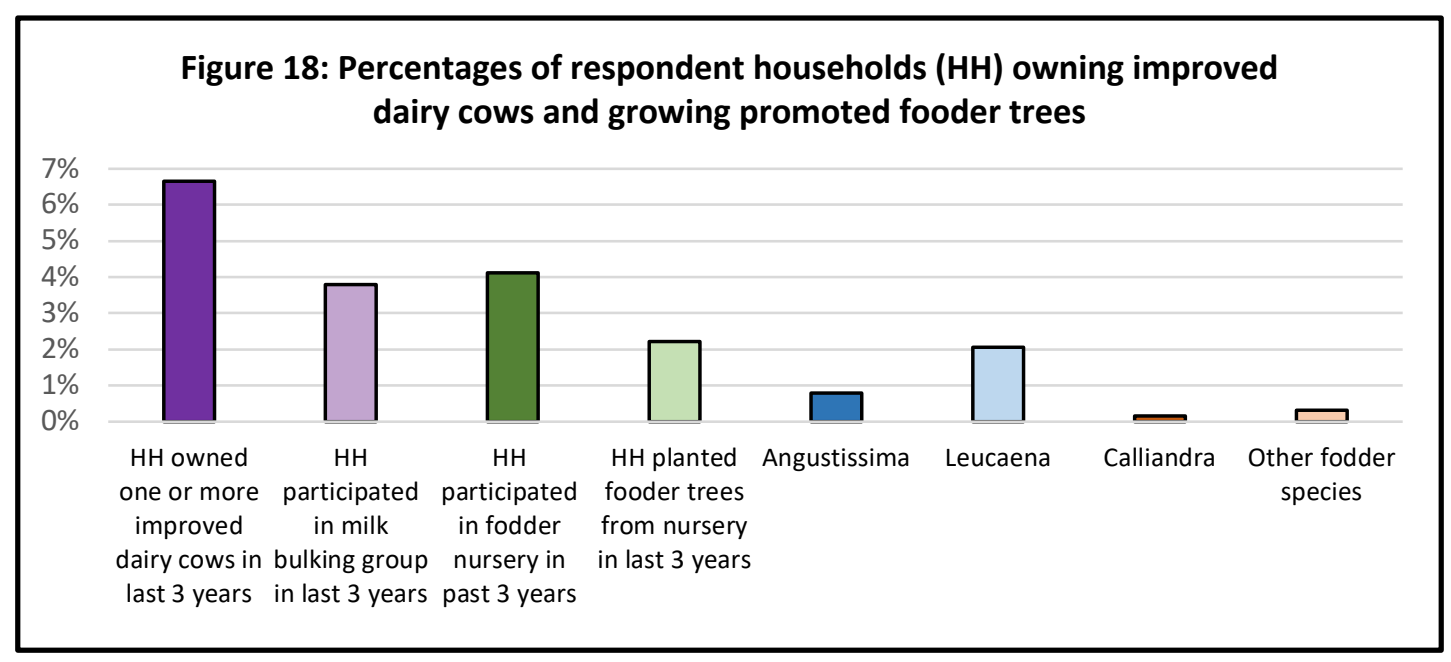

Indeed, only 11 out of the 631 respondents reported having fed their cows with leaves from fodder trees or shrubs over the past three years. These respondents were asked how their daily milk yields had changed since they started feeding their cows the fodder; Figure 19 presents the results as box plots. ${ }^{15}$ The reported increase is nearly double on average.

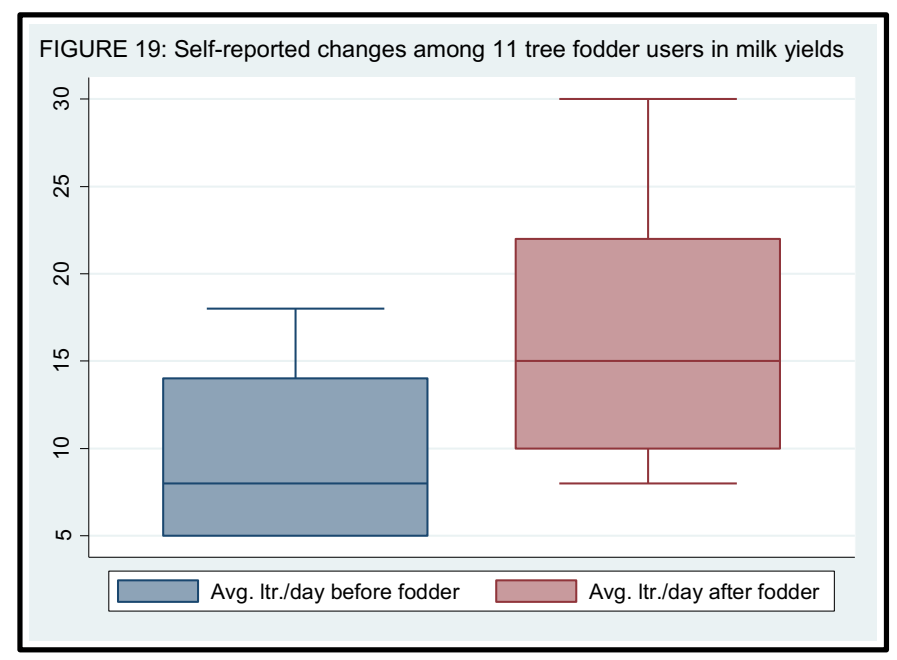

\subsection{Estimated programme outcomes and impacts}

As reported in the previous sections, the rate of successful uptake of AFSPII's fertilizer tree component was estimated at $14 \%$, with the two-season incorporation of moderate to significant fertilizer tree biomass on more than half of respondents' primary maize fields used as a measure of this uptake. Moreover, $20 \%$ or less of the respondents participated in each of AFSPII's other components, with varying degrees of success and within a timeframe too short to expect potential impacts to manifest fully. Given this limitation, we would not realistically expect to see significant differences between Year 1 and Year 3 participants - at least on average-on the various outcome and impact measures, particularly after controlling for non-programme-related variables such as baseline wealth status. The following subsections compare the two groups in relation to outcome variables including maize yields,

\footnotetext{
${ }^{15}$ From bottom to top: the first whisker to the box represents the first quartile (25th percentile); the start of the box to the middle line represents the second quartile ( $50^{\text {th }}$ percentile); the middle line to the end of the box represents the third quartile ( $75^{\text {th }}$ percentile); and the end of the box to the end of the last whisker represents the fourth quartile (100 ${ }^{\text {th }}$ percentile).
} 
household consumption expenditure, asset accumulation, food security and wood fuel access to verify our hypothesis.

Each of these subsections includes tables that present both the raw and model derived differences between the Year 1 and Year 3 participants. We used between four and five econometric models to avoid over-reliance on any single model, serving as a robustness check. These models included: IPWRA or doubly robust regression; OLS regression with robust standard errors; robust regression; propensity score matching (PSM) kernel; and quintile regression.

We also analysed several measures for each outcome construct as another robustness check as well as to explore whether the programme affected specific dimensions of these constructs. The measured differences between the Year 1 and Year 3 participants (see subsection 5.1) at the 10\% level and net of implementation site were included in all the econometric models except for the differenced asset measures. The baseline estimates of these measures were not included because these baseline values already formed part of the outcome measure itself. The independent variables (covariates) we used in the models include:

- respondent's age;

- number of years the respondent has resided in village;

- household size;

- number of productive adults in the household;

- maximum years of education of anyone in the household;

- respondent is from the Lome ethnic group;

- respondent is from another ethnic group;

- respondent is a widower;

- respondent engages in causal labour;

- respondent engages in unskilled wage labour;

- household head engages in productive work;

- 2011 asset index constructed using principal component analysis; and

- An asset index constructed with the same assets owned in 2011 and weighted by 2015 consumption expenditure data.

While the relatively modest sample size was certainly a limiting factor, we also explored the extent to which AFSPII may have affected specific subgroups differently. These subgroups were defined by: programme site; participant gender; baseline wealth status; participant education; land holding size; and whether the participant held an official position. The results of these analyses are presented in annex 3 and as graphs in each of the following subsections.

\subsubsection{Reported 2014/2015 maize yields}

Respondents were asked about the cultivation of maize in the 2014/2015 farming season, including the area planted, kilograms of shelled maize harvested and input-related expenses. If the fertilizer trees worked to improve soil fertility in a significant way, we would expect either higher maize yields among the Year 1 participants or lower in put costs - and corresponding higher returns on investment - all other things being equal and assuming that the Year 1 participants incorporated the requisite biomass. We planned to compare the Year 1 and Year 3 participants on several measures constructed from the data on maize cultivation in the 2014/2015 season. Table 11 presents the gross and modelderived results. There were no statistically significant differences between the two groups on any of the measures, which is unsurprising given that relatively few Year 1 participants managed to incorporate significant fertilizer tree biomass. Figure 20 shows box plots for the two groups related to kilograms of shelled maize per acre. It is clear that the distributions are almost completely identical. 
We may wish to simply compare all those participants who successfully incorporated significant fertilizer tree biomass with those that did not. However, we must recognize that such a comparison is likely to be confounded by both observable and unobservable differences between the two groups. (We already noted in Yable 10 for example that the successful adopters were more likely to be wealthier and more educated at baseline.) Figure 21 presents the box plots for the two groups. Maize yields were on average higher for the successful adopters ( $p=0.026$ after holding site-specific effects fixed). However, this statistical significance disappears after controlling for baseline asset wealth status.
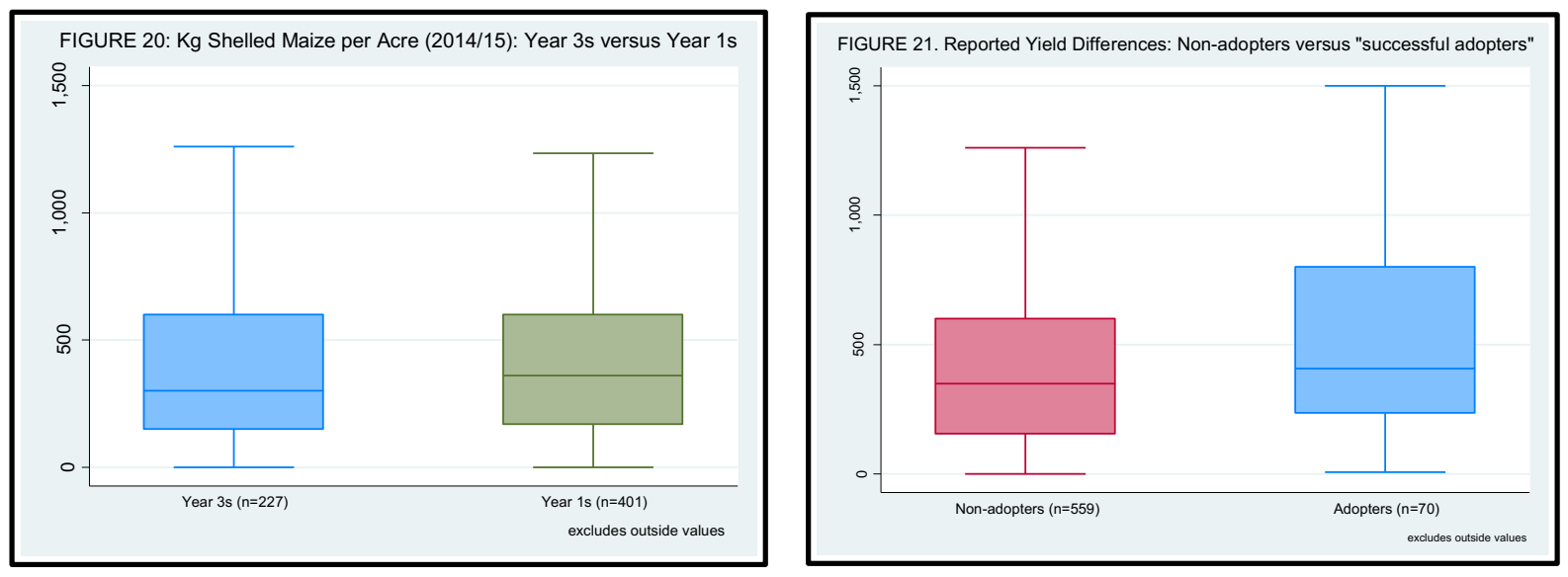

Table A31 in annex 3 presents the results of the sub-group analysis of the various maize measures. Very few statistically significant subgroup-specific effects were identified. The results of the interaction tests for men versus women and primary school attendees versus non-primary school attendees are statistically significant. However, we found that these results were driven by extreme values, given that they are no longer statistically significant following the application of robust regression.

Several other modest interaction effects are significant at the $10 \%$ level. For example, Year 1 men reported higher yields per acre than Year 3 men, which was not the case for women. Year 1 participants in Mzimba also reported greater yields than Year 3 participants in this district; Figure 22 displays these differences. District officials involved in the project informed us that 700 kilograms of shelled maize per acre is considered a good maize yield. Therefore, we considered constructing a

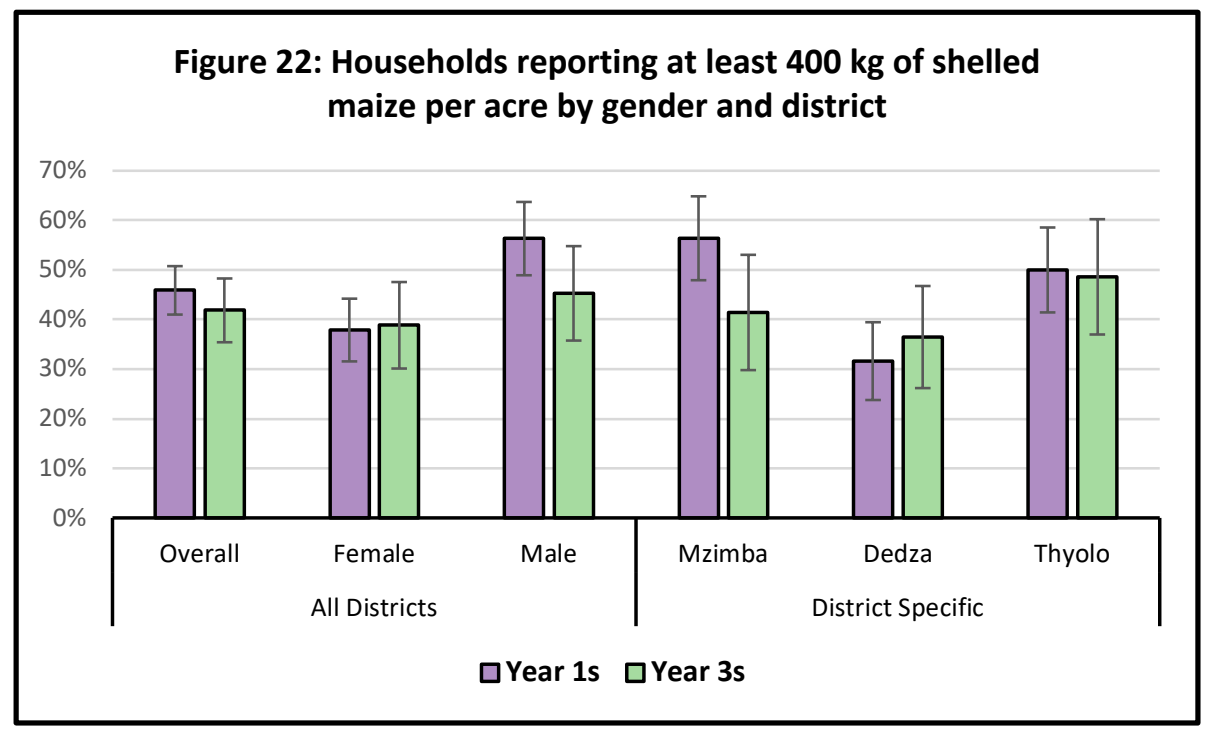


binary measure using this threshold. However, relatively few participants reported this level of yield. Consequently, we used $400 \mathrm{~kg}$ per acre as the cut off. Figure 22 presents the raw comparison overall and disaggregated by gender and district. While only statistically significant for the continuous measure, the raw difference between Year 1 and Year 3 men in Figure 22 is clear in the graph, as is the modest statistically significant difference for Mzimba District. However, in the absence of baseline data on maize yields - coupled with data from the analysis of biomass incorporation above - we are reluctant to speculate that this could be due to the programme. In fact, there is a strong possibility that these differences reflect pre-existing conditions or were driven by non-programmatic factors.

Table 11: 2014/2015 maize harvest measures - Year 1 versus Year 3

\begin{tabular}{|c|c|c|c|c|c|c|}
\hline & $\begin{array}{c}\text { Kg of shelled } \\
\text { maize }\end{array}$ & $\begin{array}{l}\text { Kg of shelled } \\
\text { maize per acre }\end{array}$ & $\begin{array}{c}\text { Kg of shelled } \\
\text { maize per acre } \\
(\log )\end{array}$ & $\begin{array}{c}\text { At least } 400 \mathrm{~kg} \\
\text { shelled maize } \\
\text { per acre }\end{array}$ & $\begin{array}{l}\text { Production cost } \\
\text { of shelled maize } \\
\text { per } \mathrm{kg}(\mathrm{MKW}) \\
\end{array}$ & $\begin{array}{l}\text { Production cost } \\
\text { of shelled maize } \\
\text { per } \mathrm{kg}(\log )^{16}\end{array}$ \\
\hline \multicolumn{7}{|l|}{ Raw results } \\
\hline Sample mean & 736.47 & 482.31 & 5.71 & 0.44 & 44.19 & 4.89 \\
\hline Year 1 mean & 783.02 & 501.49 & 5.75 & 0.46 & 45.02 & 4.9 \\
\hline Year 3 mean & 654.61 & 448.43 & 5.64 & 0.42 & 42.73 & 4.87 \\
\hline \multirow{2}{*}{$\begin{array}{l}\text { Unadjusted } \\
\text { difference }\end{array}$} & 128.4 & 53.1 & 0.11 & 0.040 & 2.29 & 0.020 \\
\hline & $(84.8)$ & $(40.8)$ & $(0.095)$ & $(0.041)$ & $(7.36)$ & $(0.029)$ \\
\hline Observations & 629 & 628 & 620 & 628 & 624 & 624 \\
\hline Sample median & 400 & 358.57 & 5.89 & 0 & 19.65 & 4.78 \\
\hline Year 1 median & 450 & 360 & 5.89 & 0 & 20 & 4.79 \\
\hline Year 3 median & 360 & 300 & 5.7 & 0 & 17.86 & 4.77 \\
\hline \multirow{2}{*}{$\begin{array}{l}\text { Unadjusted } \\
\text { difference }\end{array}$} & $90 *$ & $60 *$ & $0.18^{*}$ & 0 & 2.14 & 0.018 \\
\hline & $(48.2)$ & $(34.0)$ & $(0.098)$ & $(0.18)$ & (4.10) & $(0.034)$ \\
\hline Observations & 629 & 628 & 620 & 628 & 626 & 626 \\
\hline \multicolumn{7}{|l|}{ IPWRA } \\
\hline coefficient & 23.8 & 27.1 & 0.046 & 0.012 & 0.67 & 0.0088 \\
\hline & (90.2) & (43.9) & $(0.089)$ & $(0.042)$ & $(6.41)$ & $(0.028)$ \\
\hline Observations & 618 & 617 & 609 & 617 & 615 & 615 \\
\hline \multicolumn{7}{|l|}{ OLS } \\
\hline coefficient & 54.0 & 41.8 & 0.10 & 0.090 & -3.02 & -0.0036 \\
\hline & (86.9) & (44.2) & $(0.093)$ & $(0.12)$ & (6.88) & $(0.029)$ \\
\hline Observations & 618 & 617 & 609 & 617 & 615 & 615 \\
\hline \multicolumn{7}{|l|}{ Robust OLS } \\
\hline coefficient & 39.9 & 16.8 & 0.066 & -- & 2.10 & 0.015 \\
\hline & (32.3) & $(25.6)$ & $(0.082)$ & & $(2.51)$ & $(0.021)$ \\
\hline Observations & 614 & 617 & 609 & & 626 & 613 \\
\hline \multicolumn{7}{|l|}{ PSM kernel } \\
\hline coefficient & -105.3 & 5.109 & -0.0600 & -0.0213 & 7.328 & 0.0332 \\
\hline & (137.6) & $(55.94)$ & $(0.107)$ & $(0.0531)$ & $(6.170)$ & $(0.0314)$ \\
\hline Observations & 591 & 590 & 582 & 590 & 588 & 588 \\
\hline \multicolumn{7}{|c|}{ Quintile regression } \\
\hline coefficient & 25.7 & 21.1 & 0.14 & -- & 1.14 & 0.0056 \\
\hline & (43.2) & (37.3) & $(0.11)$ & & $(3.51)$ & $(0.028)$ \\
\hline Observations & 618 & 617 & 609 & & 615 & 615 \\
\hline
\end{tabular}

\footnotetext{
16116 respondents reported no maize production costs, so a scalar of 100 was added to the production cost per kilogram to enable these values to be included following logarithmic transformation.
} 


\subsubsection{Household consumption expenditure}

Measuring household income and wealth in low- and middle-income countries is not straightforward, particularly in rural areas where respondents tend to be self-employed. Self-reported measures of total income can be unreliable given that such households are often involved in a wide variety of livelihood pursuits (Morris et al. 2000). However, given the strong and widely recognized association between household income and consumption, a popular proxy measure used by the World Bank and other international institutions is household consumption expenditure (Deaton and Zaidi 1999). It is through such data that the percentages of households living above and below the poverty line are estimated.

To collect these data, several modules were incorporated into the household survey. Respondents were asked what types of food they consumed over the previous seven-day period as well as the quantities of each food item consumed. The quantities were then assigned a monetary value by asking each respondent how much was paid for each food item (or if the food item was sourced through the household's own production, how much it would have cost if it was purchased from the local market). Respondents were also asked how much they spent on particular non-food items and services (regular non-food expenditures) from a detailed list, including soap, toothpaste and minibus fares over the past four weeks. Finally, they were asked about "big ticket" expenditures such as school and hospital fees, clothes and home repair (irregular non-food expenditures) included on another pre-defined list over the last 12 months.

The basic per capita measure was calculated for each household as follows:

- The weekly cash value of each food item consumed during the past seven days was added together and divided by seven, thereby estimating the daily cash value of food consumed by the household.

- Household expenditures on items from both the regular monthly non-food expenditure and annual non-food expenditure lists were added together and divided by 30 and 365 respectively, thereby estimating the household's average daily expenditure on regular and irregular non-food items.

- The daily consumption expenditures estimated for food and regular and irregular non-food items were then added together and converted into US dollars while adjusting for purchasing power parity (PPP). ${ }^{17}$

- Finally, to derive each household's per capita consumption expenditure, its PPP adjusted dollar value was divided by the number of its members (household size), with another adjustment made for assumed lower consumption among children and economies of scale. ${ }^{18}$

Table 12 compares Year 1 and Year 3 participants against several variables constructed from the resulting consumption expenditure data. The first is the primary variable described above, while the second is the standard practice of placing this variable on a logarithmic scale to both normalize the distribution and countervail the influence of extreme values. This is followed by two binary measures

\footnotetext{
${ }^{17}$ Adjustments were made for PPP in order to take into account each country's different purchasing power (i.e. the quantity of currency required to purchase a given basket of goods and services). The PPP conversion rates used were taken from the World Bank's website: http://data.worldbank.org/indicator/PA.NUS.PPPC.RF.

18 While dividing PPP by household size as the overall denominator is recommended in the literature, we considered it important to avoid underestimating larger-sized households' expenditures relative to smaller households. A recommended formula for computing household size for this purpose is: household size $=(A+$ $\alpha K)^{\theta}$ where $A$ is the number of adults in the household; $K$ is the number of children; $\alpha$ is the cost of a child relative to an adult; and $\theta$ controls for economies of scale. For low-income countries, is recommend that $\alpha$ be set at .25 or .33 , and $\theta$ be set at .9 (Ibid).
} 
for households above and below the international poverty and ultra-poverty lines respectively. The last two variables focus on food expenditures.

Table 12. Household consumption expenditure - Year 1 versus Year 3 participants (overall)

\begin{tabular}{|c|c|c|c|c|c|c|c|}
\hline & $\begin{array}{c}\text { Adult } \\
\text { equivalent } \\
\text { daily per } \\
\text { person } \\
\text { expenditure } \\
\text { (PPP) } \\
\end{array}$ & $\begin{array}{c}\text { Log of } \\
\text { adjusted } \\
\text { daily per } \\
\text { person } \\
\text { expenditure } \\
\text { (PPP) } \\
\end{array}$ & $\begin{array}{c}\text { Household } \\
\text { at least } \\
\text { USD } 1.90 \\
\text { per capita } \\
\text { per day } \\
\text { (PPP) } \\
\end{array}$ & $\begin{array}{c}\text { Household } \\
\text { below } \\
\text { USD } 1.25 \\
\text { per capita } \\
\text { per day } \\
\text { (PPP) } \\
\end{array}$ & $\begin{array}{l}\text { Daily food } \\
\text { expenditure } \\
\text { per capita in } \\
\text { USD (PPP) }\end{array}$ & $\begin{array}{c}\text { Proportion } \\
\text { of household } \\
\text { expenditure } \\
\text { on food }\end{array}$ & Observations \\
\hline \multicolumn{8}{|l|}{ Raw results } \\
\hline Sample mean & 2.63 & 0.65 & 0.5 & 0.29 & 1.35 & 0.58 & 626 \\
\hline Year 1 Mean & 2.75 & 0.69 & 0.51 & 0.28 & 1.35 & 0.56 & 399 \\
\hline Year 3 mean & 2.41 & 0.59 & 0.47 & 0.3 & 1.35 & 0.61 & 227 \\
\hline \multirow{2}{*}{$\begin{array}{l}\text { Unadjusted } \\
\text { difference }\end{array}$} & $0.34^{*}$ & 0.10 & 0.047 & -0.016 & 0.0038 & $-0.043 * *$ & \\
\hline & $(0.18)$ & $(0.066)$ & $(0.042)$ & $(0.038)$ & $(0.088)$ & $(0.018)$ & \\
\hline Sample median & 1.88 & 0.63 & 0 & 0 & 1.11 & 0.59 & 626 \\
\hline Year 1 median & 1.98 & 0.68 & 1 & 0 & 1.11 & 0.58 & 399 \\
\hline Year 3 median & 1.78 & 0.58 & 0 & 0 & 1.07 & 0.63 & 227 \\
\hline \multirow{2}{*}{$\begin{array}{l}\text { Unadjusted } \\
\text { difference }\end{array}$} & 0.20 & 0.11 & -- & -- & 0.039 & $-0.053 * *$ & \\
\hline & $(0.16)$ & $(0.082)$ & & & $(0.081)$ & $(0.026)$ & \\
\hline $\begin{array}{l}\text { IPWRA } \\
\text { coefficient }\end{array}$ & $\begin{array}{c}0.25 \\
(0.17)\end{array}$ & $\begin{array}{c}0.075 \\
(0.058)\end{array}$ & $\begin{array}{c}0.035 \\
(0.039)\end{array}$ & $\begin{array}{c}-0.01 \\
(0.035)\end{array}$ & $\begin{array}{c}0.050 \\
(0.079)\end{array}$ & $\begin{array}{l}-0.021 \\
(0.019)\end{array}$ & 620 \\
\hline $\begin{array}{l}\text { OLS } \\
\text { coefficient }\end{array}$ & $\begin{array}{c}0.25 \\
(0.18)\end{array}$ & $\begin{array}{c}0.084 \\
(0.060)\end{array}$ & $\begin{array}{c}0.12 \\
(0.12)\end{array}$ & $\begin{array}{l}-0.099 \\
(0.13)\end{array}$ & $\begin{array}{c}0.042 \\
(0.083)\end{array}$ & $\begin{array}{l}-0.022 \\
(0.019)\end{array}$ & 620 \\
\hline $\begin{array}{l}\text { Robust OLS } \\
\text { coefficient }\end{array}$ & $\begin{array}{c}0.13 \\
(0.11)\end{array}$ & $\begin{array}{c}0.10^{*} \\
(0.061)\end{array}$ & -- & -- & $\begin{array}{c}0.061 \\
(0.065)\end{array}$ & $\begin{array}{l}-0.023 \\
(0.020)\end{array}$ & 620 \\
\hline $\begin{array}{l}\text { PSM kernel } \\
\text { coefficient }\end{array}$ & $\begin{array}{c}0.109 \\
(0.231)\end{array}$ & $\begin{array}{c}0.0249 \\
(0.0816)\end{array}$ & $\begin{array}{r}-0.00923 \\
(0.0505)\end{array}$ & $\begin{array}{l}0.00724 \\
(0.0477)\end{array}$ & $\begin{array}{c}0.0113 \\
(0.0923)\end{array}$ & $\begin{array}{c}-0.0205 \\
(0.0231)\end{array}$ & 593 \\
\hline $\begin{array}{l}\text { Quintile MVR } \\
\text { coefficient }\end{array}$ & $\begin{array}{c}0.22 \\
(0.16)\end{array}$ & $\begin{array}{l}0.14^{* *} \\
(0.068)\end{array}$ & -- & -- & $\begin{array}{c}0.11 \\
(0.090)\end{array}$ & $\begin{array}{l}-0.0084 \\
(0.025)\end{array}$ & 620 \\
\hline
\end{tabular}

Standard errors in parentheses

$* \mathrm{p}<0.1, * * \mathrm{p}<0.05, * * * \mathrm{p}<0.01$

PSM kernel estimates bootstrapped 1,000 repetitions with exact matching within districts and sub-district in the case of Dedza

Coefficients for covariates used are not presented.

From Table 12, it is clear that Year 1 and Year 3 participants were nearly on par with respect to estimated consumption expenditures, with about half of both groups above the international poverty line. This is also clear in Figure 23, where box plots for the two groups are nearly identical. 
While no average overall differences were found between the Year 1 and Year 3 participants, there were several subgroup-specific differences, as reflected in Table A32 in annex 3 . Figure 24 reveals how Year 1 participants in Thyolo District are better off than those in Year 3 within the same district with respect to the log transformed variation of consumption expenditure measure (an estimated average of $27 \%$ were rated as better off).
FIGURE 23: Household Consumption Expenditure: Old versus New Partcipants

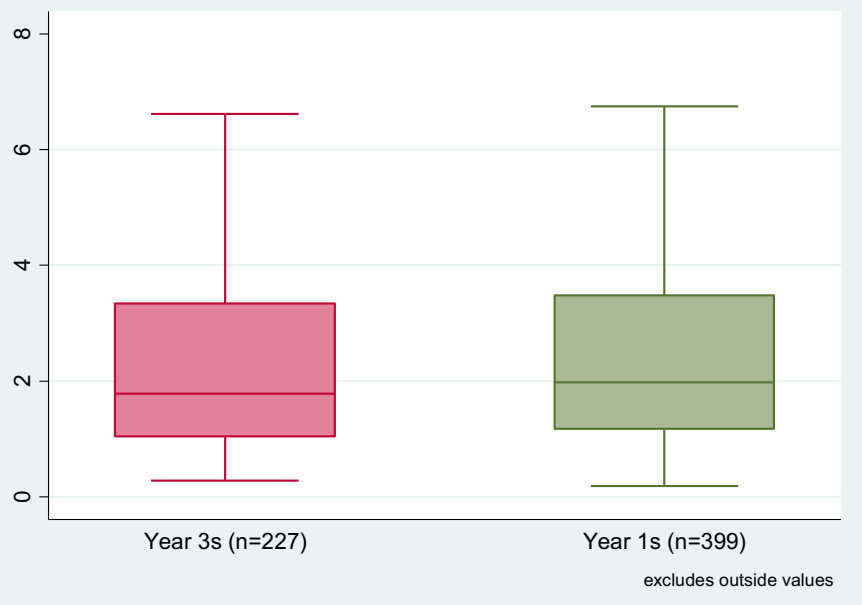

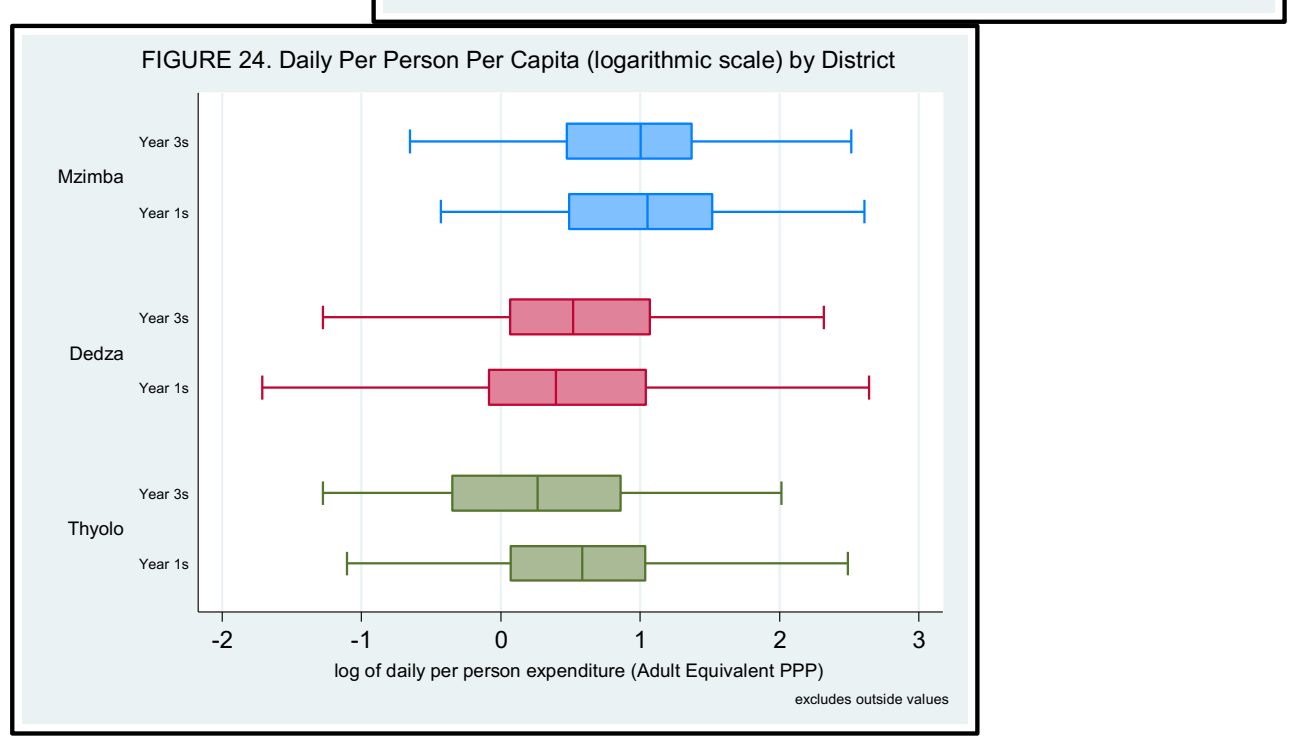

Figure 25 presents another example with regard to landholding size. While those farmers with more land are estimated to have higher consumption expenditure than those with less, Year 1 participants were estimated to be about $26 \%$ better off than those from Year 3 in this category. While these differences by district and land holding size are revealing, given an absence of baseline data, they may

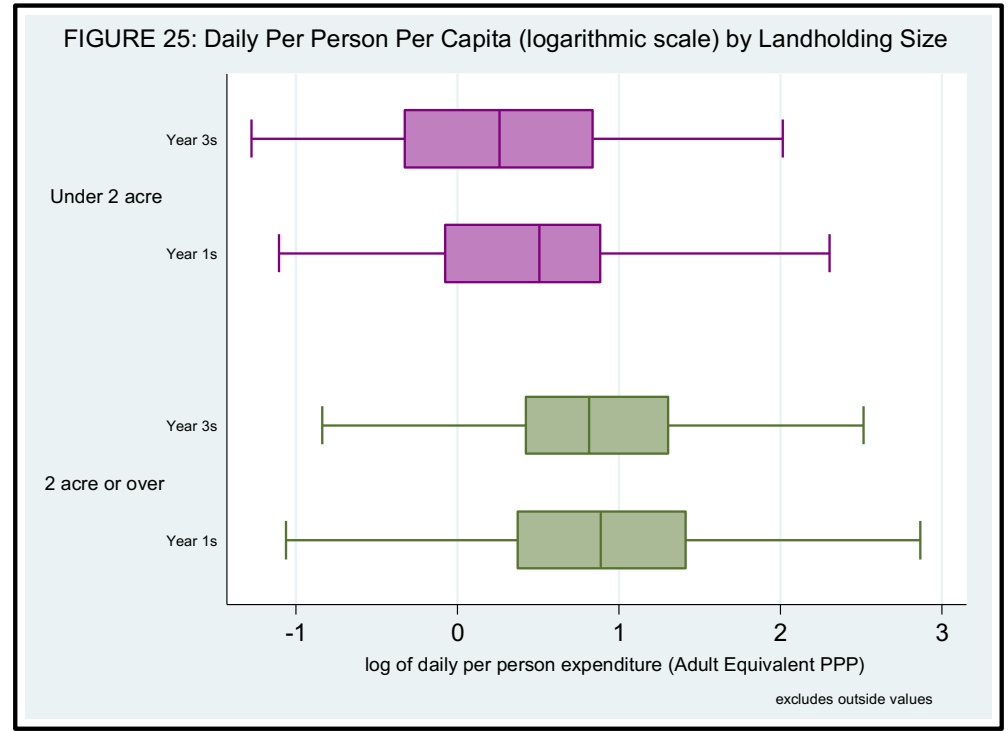


simply be indicative of pre-existing differences. If these differences persisted for the asset measures - for which we had baseline data we assumed to have been reliably recalled - we could be much more confident that they might have resulted from AFSPII.

\subsubsection{Household asset measures}

As explained above, a household's wealth status in low- and middle-income countries is often measured using consumption expenditure data. An alternative is to analyse the assets a household owns and other wealth indicators, such as the materials used to construct a household's roof or floor. Consumption expenditure data are generally recognized as more sensitive to recent changes in household income, while asset-based measures typically reflect a household's more established wealth status (Moser and Felton 2007). This is because increases in household income need to be sustained for some time before they translate into significant increases in household asset ownership. In other words, after a household's income has been sustainably increased, it take time will for that household to accumulate assets, make home improvements, etc.

During the survey, respondents were asked whether they or anyone in their household currently owned particular assets and other wealth indicators from a list of 86 items (see annex 4). We then tested the inter-item correlation among these assets. ${ }^{19}$ Assets with negative signs were dropped, leaving a streamlined set of household wealth indicators with positive correlations among them. The inter-item correlation (measured with Cronbach's alpha statistic) was 0.8978 for 2015 and 0.8870 for 2011.

Taking advantage of the available 2015 consumption expenditure data, we created two asset indices for both 2015 and 2011 that were weighted by these data. Starting with the 2015 assets, we first regressed all these items on our 2015 per capita consumption expenditure log measure. We then selected only those items that were at least moderately independent and positive predictors (i.e. had positive signs with $p$-values of $<0.20$ ). We regressed these shortlisted asset items on consumption expenditure data while again checking to ensure that the coefficient for each item remained positive. The resulting basket of assets explains $41 \%$ of the logged consumption expenditure data. We subsequently used Stata's predict command to construct the weighted asset index for 2015.

To construct the 2011 asset index, we took the same set of 2011 asset items shortlisted for 2015, regressed them on the 2015 consumption expenditure (adjusted $R^{2}=0.27$ ) and then used the predict command to construct a weighted index for 2011. This method ensured that the same weights derived for the 2015 shortlisted items were applied to the 2011 items, making the two indices comparable. A differenced index was finally created by differencing the 2015 and 2011 index scores for each observation.

The second variation of the asset index for each year was constructed from a tetrachoric matrix, which is used to measure the degree to which binary variables are statistically associated. Principal component factor analysis (PCA) was then run on this matrix to focus on the variation in household asset ownership, which is assumed to represent wealth status. The more an asset is correlated with this variation, the more weight it is given. Hence, each household's weighted index score is determined by both: (i) the number of assets it owns; and (ii) the particular weight assigned to each asset. This enables a comparison of the relative wealth status between groups of households.

\footnotetext{
${ }^{19}$ When items are used in a scale or index, they should all measure the same underlying latent construct (e.g. household wealth status). They must therefore be significantly correlated with one another. Cronbach's alpha is a measure of this inter-item correlation. The more the variables are correlated, the greater the sum of the common variation they share. If all items are perfectly correlated, alpha is 1 and if they are all independent from one another, alpha is 0 . An alpha of 0.7 or 0.8 is considered satisfactory for comparing groups (Bland and Altman 1997).
} 
A differenced asset index was also created by constructing another tetrachoric matrix specifically focused on gains in ownership of each wealth item between 2011 and 2015 (Cronbach's alpha = 0.73). PCA was then run on this matrix to construct a differenced index that explicitly focused on asset gains over the project lifespan.

Table 13 compares Year 1 and Year 3 participants on the various asset measures. Note that statistically significant differences existed in the raw data between the two groups for single differenced measures. However, these were erased by both the raw differencing between the two time periods and the econometric models. This clearly reveals that Year 1 participants were already wealthier on average than those in Year 3 at baseline.

Table 13. Household asset measures - Year 1 versus Year 3 participants (overall)

\begin{tabular}{|c|c|c|c|c|c|c|}
\hline & $\begin{array}{c}\text { Raw } \\
\text { household } \\
\text { asset score } \\
2015\end{array}$ & $\begin{array}{c}\text { Difference } \\
\text { raw } \\
\text { household } \\
\text { asset score }\end{array}$ & $\begin{array}{c}2015 \text { asset } \\
\text { index } \\
\text { weighted by } \\
2015 \\
\text { consumption } \\
\text { expenditure } \\
\end{array}$ & $\begin{array}{c}\text { Difference } \\
\text { asset index } \\
\text { weighted by } \\
2015 \\
\text { consumption } \\
\text { expenditure }\end{array}$ & $\begin{array}{c}\text { PCA weighted } \\
\text { asset index } \\
2015\end{array}$ & $\begin{array}{l}\text { Difference } \\
\text { PCA weighted } \\
\text { asset index }\end{array}$ \\
\hline \multicolumn{7}{|l|}{ Raw results } \\
\hline Sample mean & 10.94 & 1.7 & 1.69 & 0 & 0.3 & 0.23 \\
\hline Year 1 mean & 11.54 & 1.82 & 1.73 & 0.01 & 0.32 & 0.23 \\
\hline Year 3 mean & 9.89 & 1.48 & 1.61 & -0.01 & 0.26 & 0.21 \\
\hline \multirow[t]{2}{*}{ Unadjusted difference } & $1.65 * * *$ & 0.34 & $0.12 * * *$ & 0.017 & $0.058 * * *$ & 0.018 \\
\hline & $(0.61)$ & $(0.31)$ & $(0.045)$ & $(0.028)$ & $(0.022)$ & $(0.024)$ \\
\hline Observations & 626 & 620 & 626 & 620 & 631 & 625 \\
\hline Sample median & 9 & 1 & 1.57 & -0.05 & 0.2 & 0.19 \\
\hline Year 1 median & 9 & 1 & 1.64 & -0.04 & 0.21 & 0.19 \\
\hline Year 3 median & 8 & 1 & 1.49 & -0.05 & 0.19 & 0.18 \\
\hline \multirow{2}{*}{ Unadjusted difference } & 1 & 0 & $0.15^{* *}$ & 0.00094 & 0.021 & 0.010 \\
\hline & $(0.78)$ & $(0.37)$ & $(0.063)$ & $(0.040)$ & $(0.030)$ & $(0.032)$ \\
\hline Observations & 626 & 620 & 626 & 620 & 631 & 625 \\
\hline \multicolumn{7}{|l|}{ IPWRA } \\
\hline coefficient & 0.32 & 0.23 & 0.010 & 0.0042 & 0.012 & 0.0060 \\
\hline & $(0.30)$ & $(0.31)$ & $(0.029)$ & $(0.028)$ & $(0.014)$ & $(0.024)$ \\
\hline Observations & 620 & 620 & 620 & 620 & 625 & 625 \\
\hline \multicolumn{7}{|l|}{ OLS } \\
\hline coefficient & 0.29 & 0.20 & 0.0091 & -0.00068 & 0.010 & 0.0022 \\
\hline & $(0.30)$ & $(0.31)$ & $(0.028)$ & $(0.028)$ & $(0.015)$ & $(0.024)$ \\
\hline Observations & 620 & 620 & 620 & 620 & 625 & 625 \\
\hline \multicolumn{7}{|l|}{ Robust OLS } \\
\hline coefficient & 0.20 & 0.16 & -0.010 & -0.018 & -0.0069 & 0.0100 \\
\hline & $(0.27)$ & $(0.28)$ & $(0.029)$ & $(0.029)$ & $(0.013)$ & $(0.023)$ \\
\hline Observations & 620 & 620 & 620 & 620 & 625 & 625 \\
\hline \multicolumn{7}{|l|}{ PSM kernel } \\
\hline coefficient & 0.0983 & -0.0408 & 0.00863 & -0.0287 & 0.00484 & -0.00289 \\
\hline & $(0.725)$ & $(0.424)$ & $(0.0511)$ & $(0.0349)$ & $(0.0263)$ & $(0.0276)$ \\
\hline Observations & 593 & 593 & 593 & 593 & 593 & 593 \\
\hline
\end{tabular}

Figure 26 presents box plots for the differenced asset index weighted by 2015 consumption expenditure data for the two groups. It is clear the rate of asset accumulation over these time periods 
is nearly identical. However, the subgroup analysis did turn up one noteworthy result, as presented in Table A33 in annex 3: on average, Year 1 women participants gained less income than Year 3 women, while Year 1 men gained more than Year 3 men; Figure 27 illustrates this pattern. However, following the application of robust regression, we found that these average differences were partly driven by outliers (see footnote in Table A33).
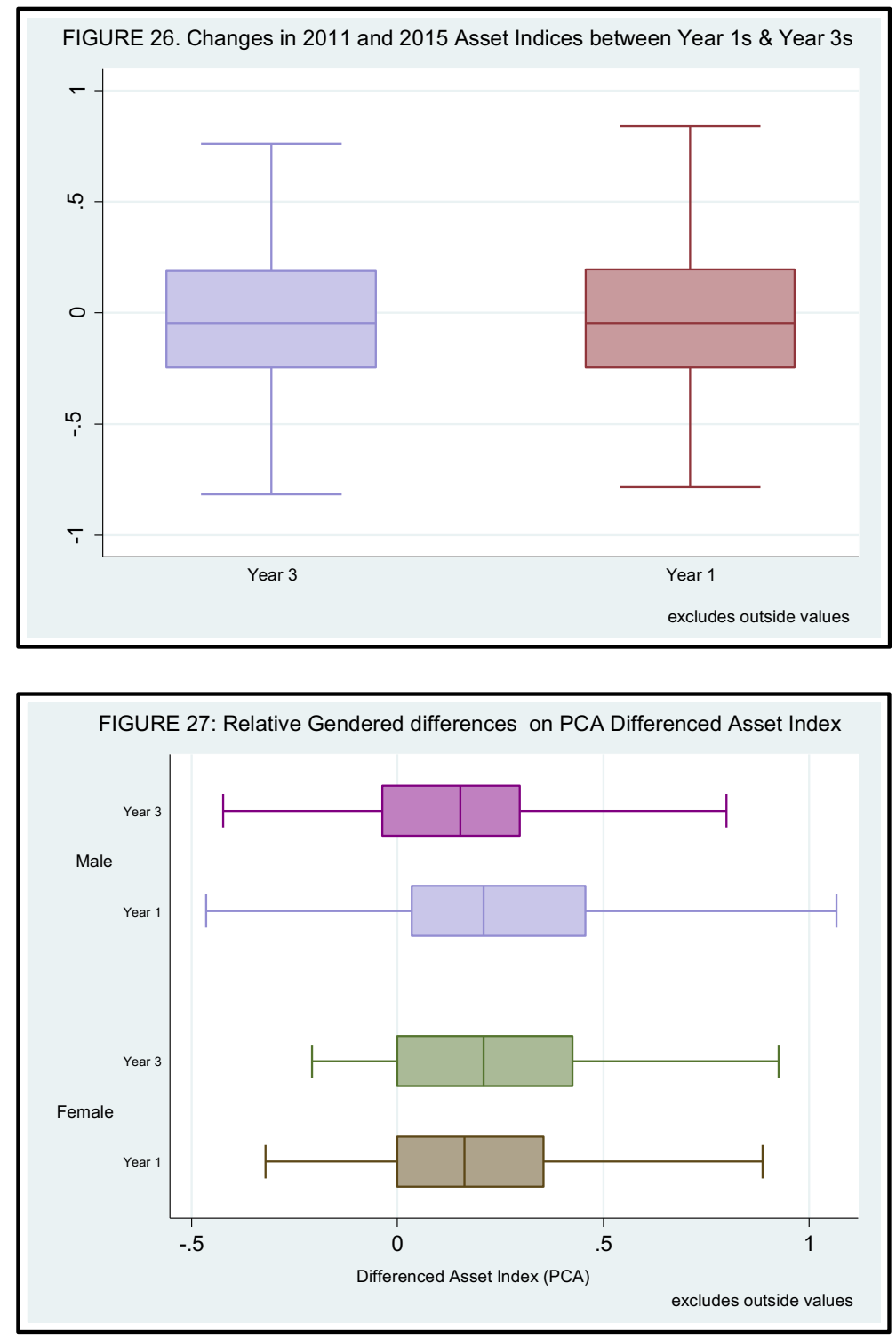

\subsubsection{Food security and other measures}

In this final subsection, we present the differences between the Year 1 and Year 3 participants for several measures of food security, self-reported changes in time collecting firewood and perceptions of soil health.

The first measure is entitled Minimum Dietary Diversity, Women (MDD-W). Capturing and analysing data on anthropometric measures such as weight-for-height, height-for-age, weight-for-age of under5 children and body mass index for adults is recognized as a valid approach for assessing a population's 
nutritional and food security. ${ }^{20}$ However, such measures are costly and time consuming to administer. As a result, several alternative measures have been proposed and the Women's Dietary Diversity Project was launched to address the need for a simple yet valid measure of women's diet quality, with a focus on micronutrient adequacy. This culminated in the development and use of the MDD-W indicator. ${ }^{21}$

To capture data on this indicator, both female and male respondents were asked whether they had consumed various foods falling into 10 categories during the previous day: (i) starchy staple foods; (ii) beans and peas; (iii) nuts and seeds; (iv) dairy; (v) fleshy foods; (vi) eggs; (vii) vitamin A-rich dark green leafy vegetables; (viii) other vitamin A-rich vegetables and fruits; (ix) other vegetables; and $(x)$ other fruits. If a respondent reported consuming at least five of the 10 items, he or she received a positive score on the binary version of this measure. As indicated in Table 14 , less than $20 \%$ of the respondents met this threshold and no statistically significant differences were found between Year 1 and Year 3 participants, particularly after the application of econometric models.

Figure 28 presents results for some of the subgroup analysis. While there was a nearly $5 \%$ difference between Year 1 and Year 3 participants, it was not statistically significant. The difference between Year 1 and Year 3 men appears large, but again is not statistically significant. In fact, the only statistically significant difference shown in the graph regards asset wealth. Year 1 participants who were more likely to be asset wealthy at baseline were also more likely to have positive MDD-W scores, while the reverse was true for those who were asset poor at baseline.

Table 14. Food security \& other measures - Year 1 versus Year 3 participants (overall)

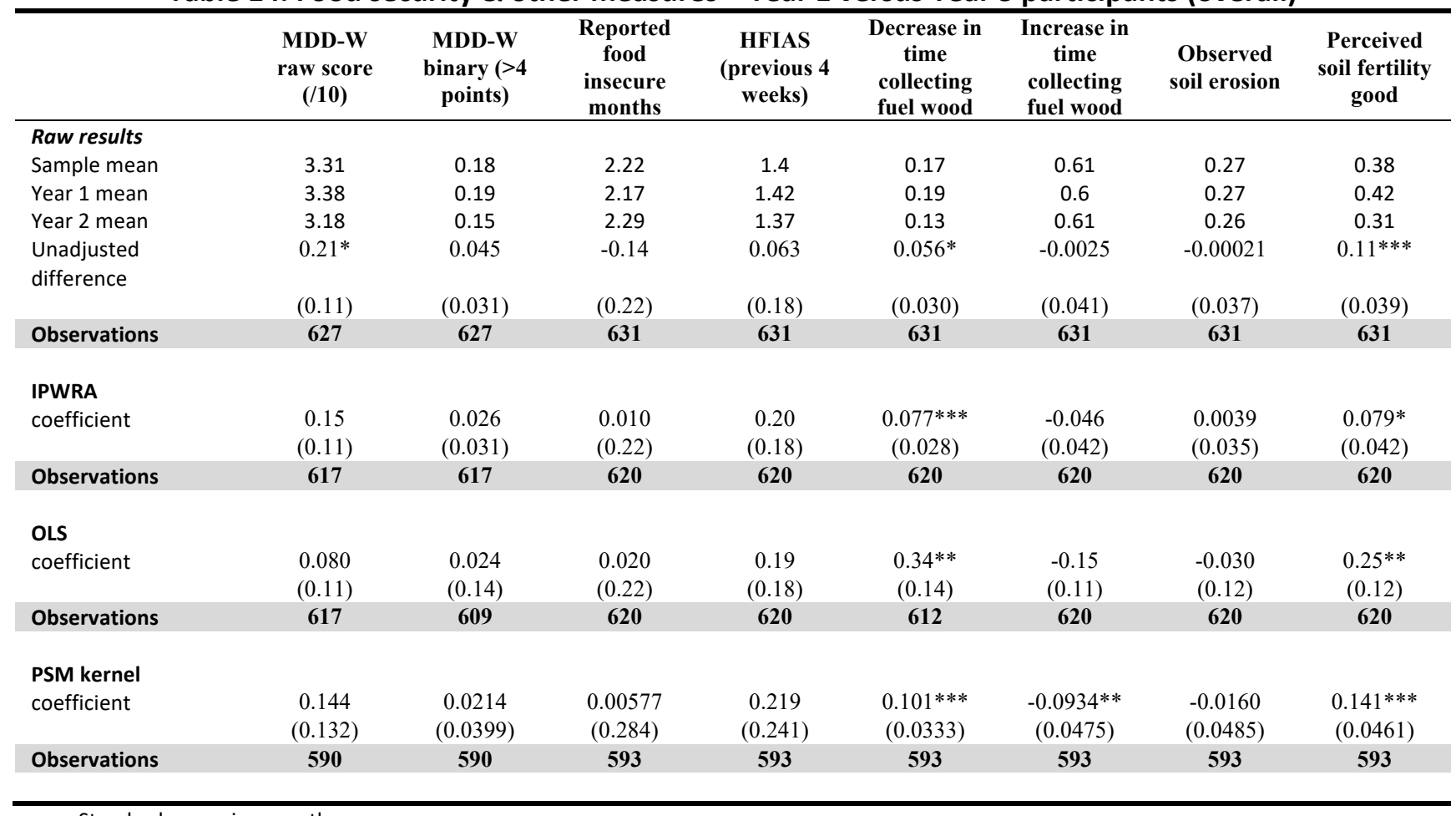

\footnotetext{
Standard errors in parentheses

$* \mathrm{p}<0.1, * * \mathrm{p}<0.05, * * * \mathrm{p}<0.01$

PSM kernel estimates bootstrapped 1,000 repetitions with exact matching within districts and sub-district in the case of Dedza.

Coefficients for covariates used are not presented.
}

For the two other food security measures - number of months in the previous year with reported food

\footnotetext{
${ }^{20}$ See World Food Programme. (2005) A Manual: Measuring and Interpreting Malnutrition and Mortality. World Food Programme Nutrition Service, Rome.

${ }^{21}$ See: http://www.fao.org/3/a-i5486e.pdf
} 
shortages and the abridged version of Household Food Insecurity Access Scale (HFIAS) ${ }^{22}$ - a similar trend emerged. For the former measure, respondents were first asked whether there were any months out of the previous 12 in which the household fell short of food. If they responded yes, they were asked which months. For the HFIAS, the respondents were asked:

(1) In the past [ 4 weeks/30 days], was there ever no food to eat of any kind in your house because of lack of resources to get food?

(2) In the past [4 weeks/30 days], did you or any household member go to sleep at night hungry because there was not enough food?

(3) In the past [4 weeks/30 days], did you or any household member go a whole day and night without eating anything at all because there was not enough food?

If a respondent answered yes to any of the three questions, he or she was asked how frequently: rarely (1-2 times -1 point); sometimes (3-10 times -2 points); or often (more than 10 times -3 points). The maximum possible score was nine points. As indicated in Table 14, there were no significant differences between the Year 1 and Year 3 participants. However, when the data were examined by wealth category (as indicated in Table A34 in annex 3), the differences were significant. Year 1 participants who were richer at baseline were slightly less likely to report food shortages than those from Year 3 in the same wealth group. Year 1 participants from the poorer group were also more likely to have higher HFIAS scores than their Year 3 counterparts. Again, given the absence of baseline data, it is impossible to conclude that this has anything to do with the work of AFSPII.

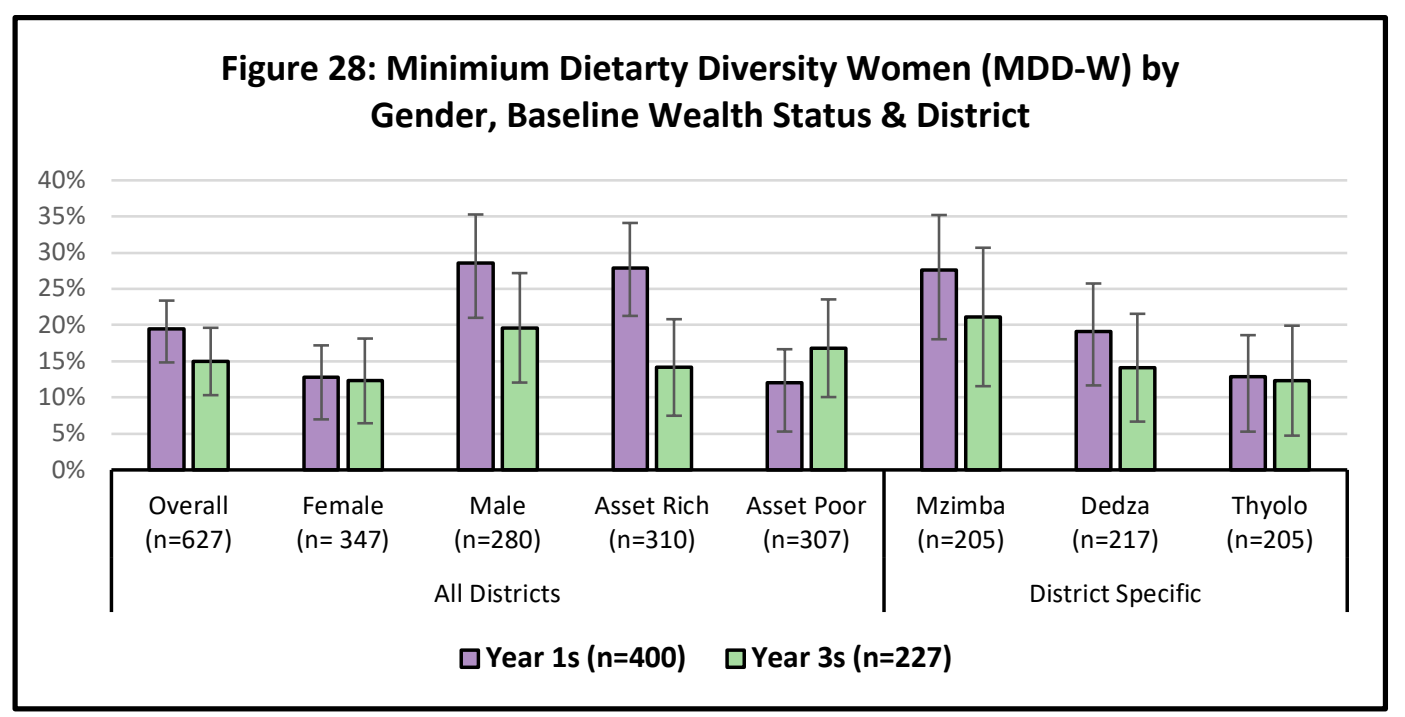

As discussed in subsection 3.2, one of the intermediate outcomes associated with AFSPII's theory of change is improved access to firewood. To assess whether the programme improved this access, respondents were asked, "Has the amount of time and effort it takes to collect or obtain this wood [for cooking and/or meeting other energy needs] changed in the last five years?". If they answered yes, they were the asked whether it had: (i) Increased to twice the time or longer; (ii) Increased but not quite doubled; (iii) decreased but not by more than half; or (iv) decreased more than half. From the responses, we constructed two binary variables: one for a reported increase in time; and the other for a reported decrease in time. The results for both are presented in Table 14; results for an increase only are shown in Figure 29 . While less than $20 \%$ of participants reported a decrease, those from Year 1 were significantly more likely than Year 3 participants to report a decrease. The pattern is less

${ }^{22}$ https://www.fantaproject.org/monitoring-and-evaluation/household-food-insecurity-access-scale-hfias 
clear for the increase-in-time variable, given that only the PSM kernel estimate is significant and in the desirable direction.

Figure 29 and Table A34 also reveal significant differences at the subgroup level among those reporting a decrease in time and efforts collecting firewood: Year 1 participant women were more likely to report a decrease than Year 3 women. Asset-poor Year 1 participants were also more than twice as likely to report a decrease than their Year 3 counterparts in the same wealth group. A similar trend exists for Thyolo District. Given that this measure indicates a change over time (albeit crude and self-reported), it is plausible that this is attributable to AFSPII participation.

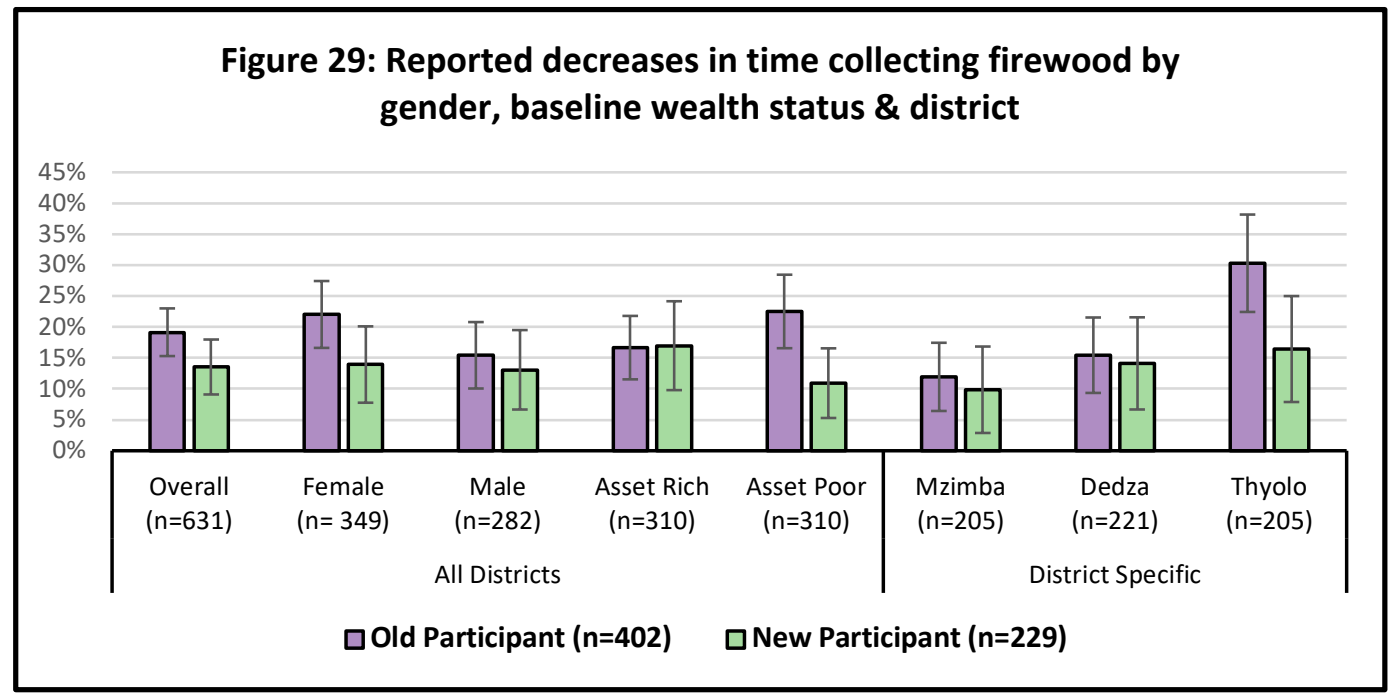

Firewood was frequently mentioned during the qualitative follow-up exercise as an additional benefit of fertilizer trees, most notably in Thyolo District. Several female farmers from Mzimba explained that they did not use fertilizer trees as firewood because they do not last as long as other species.

When the enumerators visited respondents' maize fields, they were asked to observe and gather evidence on significant soil erosion and soil fertility. We acknowledge that this means of measuring erosion and fertility has limitations. Table 14 indicates that less than $30 \%$ of the fields were reported to show significant signs of soil erosion, with no differences observed among those of Year 1 and Year 3 participants. However, Year 1 participants were more likely to report medium to high soil fertility than those from Year $3 .{ }^{23}$ Figure 30 presents overall and subgroup-specific results. Men, participants with official roles and those residing in Mzimba district from the Year 1 cohort were more likely to report positive soil fertility than their counterparts in Year 3. However, given the absence of baseline data, it is possible that these reported differences pre-existed AFSPII. In addition, because we relied on self-reported assessments of soil fertility, it is possible that the programme may have influenced participants to perceive their soil differently, irrespective of the actual conditions. It is interesting to note that "successful adopters" (those who incorporated moderate to significant biomass into their fields) were not much more likely than males or those with official roles to report medium to high soil fertility.

\footnotetext{
${ }^{23}$ The enumerators were asked to work with the respondents in coding each visited field's soil fertility as follows: (i) low: very little can grow without significant fertilizer, either chemical or organic; (ii) medium: yields are maximized with chemical or organic fertilizer use, but fair yields can be obtained without; or (iii ) high: good yields can be obtained without adding either chemical or organic fertilizers.
} 


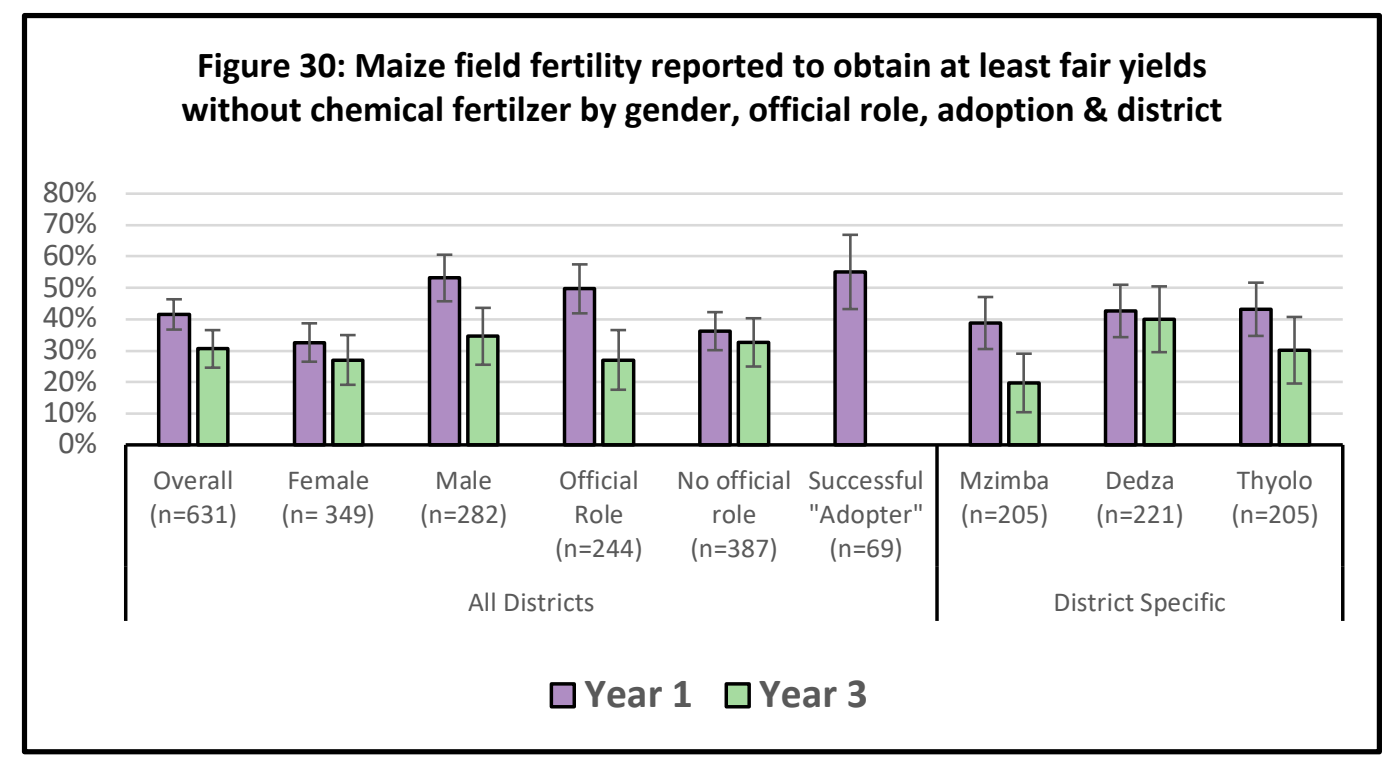

\section{Discussion and policy implications}

In this study, we sought to evaluate the impacts of AFSPII using a theory-based quasi-experimental design. Our primary approach was quantitative, but to complement our initial findings, we carried out semi-structured interviews with a sub-sample of 40 programme participants and held discussions with implementing partners. The rigour of our planned impact evaluation strategy was undermined by the fact that a number of AFSPII participants had actually commenced participation much earlier than the dates recorded in the programme database. Therefore, we were unable to compare participants who started participating in Year 1 from villages initially targeted with participants who began their participation in Year 3, and who were exclusively from purposively matched villages only included in Year 3. Indeed, a number of interviewed Year 1 and Year 3 participants were from the same villages. Comparing Year 1 and Year 3 participants was problematic because: (i) they are likely to differ in both observable and unobservable ways relevant to the outcomes of interest; and (ii) Year 3 participants' responses may have been "contaminated" by their interactions with Year 1 participants in the same villages. This issue was exacerbated by the fact that only $53 \%$ of the targeted sample size was realized and baseline data could only be reconstructed for a few key variables (e.g. household assets).

That said, this evaluation has generated several significant and policy-relevant lessons, particularly regarding the extent of uptake of the promoted agroforestry practices among AFSPII participants, which was expected to be considerably higher. In order for the full effects demonstrated at research stations and farmer field trials to manifest, the trees needed to be planted (and successfully mature) at a high density within targeted maize fields-accompanied by effective and well-timed biomass incorporation. To their credit, the ICRAF Malawi team had a scientifically grounded understanding of the required level of intensity for each type of promoted fertilizer tree system. The targets for the other three promoted agroforestry practices were established in a similar fashion.

Unfortunately, only a small proportion of AFSPII participants were able to realize the targets set for the four promoted agroforestry practices. For the fertilizer tree promotion intervention, we found that only $14 \%$ of Year 1 participants incorporated either a moderate or significant amount of fertilizer tree biomass prior to maize planting in both Year 2 and Year 3 . When we restricted this to only those who incorporated a significant amount of biomass - consistent with the programme's ambitious 
targets - this percentage is significantly smaller. This is despite the fact that most Year 1 participants did attempt to intercrop fertilizer trees in their maize fields at least once during the three-year period. The trees simply either did not do well (e.g. dried up) or were improperly managed (e.g. not pruned appropriately).

As presented in subsection 5.3, not only were the expected targets set for the other promoted practices not realized, but only certain subsets of programme participants participated in them, with their full potential impacts (e.g. fruits, timber, and fodder) only expected several years after programme closure. It should be unsurprising then that no significant average differences for the various outcome and impact measures were found in the comparison of Year 1 and Year 3 participants, except for a modest decrease in time spent collecting firewood.

While there are no quantitative data to estimate the counterfactual, our qualitative follow-up work lead us to hypothesize that successful uptake of the promoted agroforestry practices would have been much more successful if there had been more intensive monitoring, participatory review, and the provision of adaptive follow-up support. As mentioned in section 5.2.4, less than half of the participants interviewed during the qualitative follow-up referred to training or extension support visits. Those who did appear to have used the technology consistently fell into the "successful adopter" camp. These findings, coupled with the information we gathered from implementing partners, reveal that AFSPII implementation was weak overall in this respect.

Indeed, it is useful to view the promotion of fertilizer tree systems - as well as many other agriculture, agroforestry and natural resource management practices-as complex interventions. Based on evaluations undertaken in the public health sector, complex interventions are characterized by: (i) several interacting components; (ii) significant and specific behaviour change among those delivering or receiving the intervention; (iii) more than one group or organizational level targeted by the intervention; (iv) multiple potential outcomes, and expected heterogeneity of those outcomes; and (v) the need for tailoring or adapting the intervention to varying circumstances (Craig et al. 2008). It is clear that the practices promoted by AFSPII share most if not all of these attributes. Successfully implementing complex interventions in order to bring about their expected results requires significant attention to planning, monitoring, review and management. Yet both phases of AFSP were rolled out as if they were a simple intervention. Programme participants were provided with a one-time supply of tree germplasm, coupled with basic training and extension (if any). Good implementation on participants' part was expected, followed by the expected outcomes and impacts. However, for the vast majority of participants, things did not follow this simple narrative.

The complexity of adopting agroforestry and related practices, such as conservation agriculture, has been well documented (see: Meijer et al. 2015; Andersson and D'Souza 2014). There is consensus that uptake of such practices is influenced both by farmer characteristics (including age, gender, wealth status, and agro-ecological conditions) and institutional and policy factors, such as agricultural subsidies. Farmers' knowledge, perceptions, and attitudes towards the promoted technology, as well as its perceived returns and the inherent risks, are also critical.

So how does this relate to the scientific debate on the effectiveness of fertilizer tree systems in realworld settings reviewed in Section 2 ? In our view, both camps make valid points. We agree with Sileshi and Akinnifesi (2017) that simply comparing maize yields on plots with and without fertilizer trees without understanding the broader systems in which the intervention is implemented can be limiting. Based on the results of this study, we speculate that much of the variation around the mean maize yield found by Coe et al. (2016) may have been driven by differing rates of successful biomass incorporation. While we agree with Coe et al. (2017) that a simple comparison of differences in maize 
yield between plots with and within fertilizer trees is valid, it is important to acknowledge the considerable variation in successful fertilizer tree system implementation within fertilizer tree plots.

This issue is related to the distinction in the literature between "intention to treat" and "average treatment effect on the treated". The former is the average effect on those offered the programme interventions, regardless of whether they participated, while the latter is the average effect on those who actually participated. The former may relevant to policy makers, given that it can indicate what the average effect would be if the intervention was brought to scale. However, it can be limiting when there is interest in understanding the extent that those who participated were affected by the intervention (Schochet and Chiang 2011). Coe et al.'s (2016) analysis left us wondering what the average difference in maize yields would have been (as well as variation around this average) if participating farmers had successfully implemented the fertilizer tree systems. Their statement "The impact of a range of agroforestry practices on crop yield in Malawi was highly variable amongst farmers who had adopted them" (p.15) seems to imply that fertilizer tree adoption is a simple, binary process, rather than a multifaceted and complex phenomenon that can happen at varying degrees of intensity.

Consistent with other literature (e.g. Singal, Higgins, and Waljee 2014), we agree with Coe et al. (2016) that the average treatment effects of agricultural technologies, such as fertilizer trees, obtained through research stations and farmer field trials are likely to both weaken and increase in variance when they are promoted in real world settings. As we have seen from this evaluation, much of this variance is likely due to variations in the success of technology implementation, or what other literature refers to as "treatment fidelity" (Zvoch 2009). It may also be driven by the lack of an appropriate fit between the promoted technology and the agro-ecological, social or economic context (Coe et al. 2014), which may also affect its implementation. This latter point illustrates the significant tension in the treatment fidelity literature between strict adherence to the treatment model (in this case, fertilizer tree technology) versus adaptation (Blakely et al. 2002). Proponents of the former argue that tinkering with an evidence-based intervention or technology may undermine the very mechanisms that make it effective (Elliott and Mihalic 2004). Proponents of the pro-adaptation argument on the other hand view this position as unrealistic and see a need to tailor interventions to specific social, organizational, economic, and agro-ecological settings (Lee, Altschul and Mowbray 2008). A third perspective holds that adaptation may be necessary and acceptable as long as the intervention's critical components-identified through theoretical or empirical means-are left intact (Century, Rudnick and Freeman 2010).

This evaluation finds that farmers did not take up the promoted practices in the way that was envisaged; indeed, the rate of successful adoption was found to be considerably low. This does not mean that the participating farmers were uninterested in the promoted practices or that they are inherently impractical to implement in "real world conditions". On the contrary, our follow-up qualitative research revealed considerable demand for fertilizer tree systems, and those who managed to implement them successfully communicated that they found them beneficial. However, it is clear that what was being promoted fall under the 'complex intervention umbrella' and, by extension, much more intensive monitoring, follow-up support, and adaptive management would have likely resulted in successfully better uptake success than was the case.

Indeed, the scaling of AFSP was grounded in the now highly criticized agricultural research "pipeline model" (Hall et al. 2000). That is, both phases were conceived as means of scaling up fertilizer tree systems and other agroforestry practices developed through research by extension partners to farmers for their ready adoption. The need to adapt the practices and research their compatibility with real world circumstances was not seen as a priority. A clear example of this is that no significant attention was paid to the different ways in which AFSPII could affect male and female participants, 
other than a reduction in firewood-collection time that disproportionately benefitted women. Assumptions about gender roles were not validated and the programme was blind to decision-making dynamics that could have affected its impact on women farmers.

Furthermore, we found that embedding research into the scaling initiative could have proven beneficial - both for the programme and for strengthening the agroforestry evidence base. For example, AFSPII's scaling strategy could have integrated the development and systematic testing of different ways to support farmers in adopting and adapting the promoted practices, with the most effective approaches subsequently scaled up. The evidence generated from research stations and farmer field trials could also have also been augmented by evaluating the effectiveness of the practices in real world and heterogeneous farmer conditions, thereby increasing our understanding about what agroforestry practices work where, for whom, how (including their critical components), under what circumstances and at what cost. Indeed, an important opportunity was lost to strengthen the evidence base on the impacts of agroforestry, given that no well-planned impact evaluation strategy was built into the programme from the outset.

We conclude this report by making three specific recommendations relevant for researchers, donors, development organizations and policy makers engaged in agriculture and natural resource management:

1. Build in substantive provisions for participatory monitoring, follow-up support and adaptive management when scaling up complex agronomic and natural resource management interventions. Many agriculture and natural resource management interventions are complex, involving several interactive components and requiring significant behaviour change among both implementers and participants, along with adaption to match to local conditions. Successful uptake among programme participants is therefore unlikely to be achieved through the one-off provision of inputs, training and extension support. Successful uptake requires ongoing participatory monitoring with participants and other stakeholders, coupled with the tailoring of practices to varying farmers' circumstances (e.g. different levels of decision making power over uptake), and may require the introduction of "emergent" interventions (e.g. to address uncontrolled livestock grazing). This will inevitably create tension with donors that aim to reach large numbers of beneficiaries at low cost.

2. Expand the research cycle to encompass the scaling effort, particularly when there is uncertainty about technology and practice uptake and/or performance in real world settings. The research pipeline model is clearly inappropriate for complex agricultural and natural resource management interventions. In addition, truncating the research cycle-and by extension the generation of evidence-based learning-at the time when such interventions are ready to be scaled up is problematic. Research can be undertaken to identify cost-effective ways of supporting participants in the successful uptake of new technologies or practices, and tailoring them to their own circumstances. This research can be useful for testing how well such technologies and practices work in farmers' fields, and across other heterogeneous settings using a more rigorous and systematic strategy than Coe et al. (2016) were able to pursue, given the nature of the available data. Indeed, empirical research can be built into the scaling process to understand how the technology or practice performs differentially across contexts, and the critical components that bring about its intended effects. These data can be invaluable for guiding decisions on technology or practice adaptation, and determining the kind of support needed for their successful uptake by different types of farmers. This recommendation is consistent with the research-in-development paradigm advocated by Coe et al. (2014). 
3. Ensure that a robust impact evaluation strategy is pursued from the outset and view it as an integral part of the larger research effort. Given that treatment effect estimates obtained in tightly controlled research settings are likely to be diluted when the technology or practice in question is implemented in the "real world", findings regarding the former cannot be directly extrapolated to the latter. There is a need to assess how technologies and practices developed and tested in research settings perform in less controlled settings. Moreover, the agro-ecological, socio-cultural, economic, and institutional context in which the scaling takes place is likely to be more heterogeneous than that in which the technology or practice was initially developed and tested. This presents an opportunity to assess how the performance of such technologies and practices varies with conditions, as noted in recommendation 2. Assessing the effects of a technology or practice in "real world" conditions on intermediary outcomes, such as crop yields, and how these effects vary across conditions, is much more rigorous if pursued from the outset of an intervention (just as for any field experiment). In addition, such a well-planned and implemented impact evaluation can also rigorously assess the impacts of the overall scaling effort on more distal outcomes, such as total farm productivity and household food security and consumption expenditure. This should all be viewed as an integral part of the research effort, and not left as something to be pursued using unscientifically grounded methods, such as before and after analysis. 


\section{References}

Ajayi, Oluyede Clifford, Frank Place, Festus Kehinde Akinnifesi and Gudeta Weldsesemayat Sileshi. 2011. "Agricultural Success from Africa: The Case of Fertilizer Tree Systems in Southern Africa (Malawi, Tanzania, Mozambique, Zambia and Zimbabwe)." International Journal of Agricultural Sustainability 9 (1): 129-36.

Akinnifesi, Festus K, OC Ajayi, G Sileshi, PW Chirwa and Jonas Chianu. 2010. "Fertiliser Trees for Sustainable Food Security in the Maize-Based Production Systems of East and Southern Africa. A Review." Agronomy for Sustainable Development 30 (3): 615-29.

Andersson, Jens A and Shereen D'Souza. 2014. "From Adoption Claims to Understanding Farmers and Contexts: A Literature Review of Conservation Agriculture (CA) Adoption among Smallholder Farmers in Southern Africa." Agriculture, Ecosystems \& Environment 187: 116-32.

Beedy, T.L., OC Ajayi, QW Sileshi, G. Kundglande, G. Chiundu and AJ Simons. 2012. "Scaling up Agroforestry to Achieve Food Security and Environmental Protection among Smallholder Farmers in Malawi." Journal of Field Actions 8 (7): 0-8.

Blakely, Craig H, Jeffrey P Mayer, Rand G Gottschalk, Neal Schmitt, William S Davidson, David B Roitman and James G Emshoff. 2002. "The Fidelity-Adaptation Debate: Implications for the Implementation of Public Sector Social Programs BT - A Quarter Century of Community Psychology: Readings from the American Journal of Community Psychology." In , edited by Tracey A Revenson, Anthony R D'Augelli, Sabine E French, Diane L Hughes, David Livert, Edward Seidman, Marybeth Shinn, and Hirokazu Yoshikawa, 163-79. Boston, MA: Springer US.

Bland, J Martin and Douglas G Altman. 1997. "Statistics Notes: Cronbach's Alpha." BMJ 314 (7080): 572.

Caliendo, Marco and Sabine Kopeinig. 2005. "Some Practical Guidance for the Implementation of Propensity Score Matching." SSRN eLibrary, no. 1588.

Century, Jeanne, Mollie Rudnick and Cassie Freeman. 2010. "A Framework for Measuring Fidelity of Implementation: A Foundation for Shared Language and Accumulation of Knowledge." American Journal of Evaluation 31 (2). SAGE Publications: 199-218.

Chintu, R., P. L. Mafongoya, T. S. Chirwa, M. Mwale, and J. Matibini. 2004. "Subsoil Nitrogen Dynamics As Affected By Planted Coppicing Tree Legume Fallows in Eastern Zambia." Experimental Agriculture 40 (3): 327-40.

Chirwa, Paxie W, Chin K Ong, Jumanne Maghembe and Colin R Black. 2007. "Soil Water Dynamics in Cropping Systems Containing Gliricidia Sepium, Pigeonpea and Maize in Southern Malawi." Agroforestry Systems 69 (1): 29-43.

Coe, Richard, Joyce Njoloma, and Fergus Sinclair. 2016. "Loading the Dice in Favour of the Farmer: Reducing the Risk of Adopting Agronomic Innovations." Experimental Agriculture, no. May: 1-17.

Coe, Richard, Joyce Njoloma and Fergus Sinclair. 2017. "To Control or Not to Control: How Do We Learn More about How Agronoic Innovation Perform on Farms?" Experimental Agriculture.

Cambridge University Press, 1-7.

Coe, Richard, Fergus Sinclair and Edmundo Barrios. 2014. "Scaling up Agroforestry Requires Research ' in ' rather than ' for ' Development." Current Opinion in Environmental Sustainability, no. 6: 73-77.

Craig, Peter, Paul Dieppe, Sally Macintyre, Susan Michie, Irwin Nazareth and Mark Petticrew. 2008. "Developing and Evaluating Complex Interventions: The New Medical Research Council Guidance." BMJ 337 (September). 
Deaton, Angus and Salman Zaidi. 1999. "Guidelines for Constructing Consumption Aggregates For Welfare Analysis." 217.

Elliott, Delbert S and Sharon Mihalic. 2004. "Issues in Disseminating and Replicating Effective Prevention Programs." Prevention Science 5 (1): 47-53.

Funk, Michele Jonsson, Daniel Westreich, Chris Wiesen, Til Stürmer, M. Alan Brookhart and Marie Davidian. 2011. "Doubly Robust Estimation of Causal Effects." American Journal of Epidemiology 173 (7): 761-67.

Garrity, Dennis Philip, Festus K. Akinnifesi, Oluyede C. Ajayi, Sileshi G. Weldesemayat, Jeremias G. Mowo, Antoine Kalinganire, Mahamane Larwanou, and Jules Bayala. 2010. "Evergreen Agriculture: A Robust Approach to Sustainable Food Security in Africa." Food Security 2 (3): 197-214.

Gertler, Paul J, Sebastian Martinez, Patrick Premand, Laura B. Rawlings and Christel M. J; Vermeersch. 2016. Imact Evaluation in Practice.

Glennerster, Rachel and Kudzai Takavarashra. 2013. Running Randomized Evaluations. STU-Stud. Princeton University Press.

Hall, Andrew, Norman Clark, Rasheed Sulaiman, MVK Sivamohan and B Yoganand. 2000. "New Agendas for Agricultural Research in Developing Countries: Policy Analysis and Institutional Implications." Knowledge, Technology \& Policy 13 (1): 70-91.

Kamanga, B, G Kanyama-Phiri and S Minae. 1999. "Intercropping Perennial Legumes for Green Manure Additions to Maize in Southern Malawi." African Crop Science Journal 7 (4): 355-64.

Kwesiga, F, and R Coe. 1994. "The Effect of Short Rotation Sesbania Sesban Planted Fallows on Maize Yield." Forest Ecology and Management 64 (2-3): 199-208.

Lee, Shawna J, Inna Altschul and Carol T Mowbray. 2008. "Using Planned Adaptation to Implement Evidence-Based Programs with New Populations." American Journal of Community Psychology 41 (34): 290-303.

Makumba, Wilkson, Festus K Akinnifesi, Bert Janssen and Oene Oenema. 2007. "Long-Term Impact of a Gliricidia-Maize Intercropping System on Carbon Sequestration in Southern Malawi." Agriculture, Ecosystems \& Environment 118 (1-4): 237-43.

Meijer, Seline S, Delia Catacutan, Gudeta W Sileshi and Maarten Nieuwenhuis. 2015. "Tree Planting by Smallholder Farmers in Malawi: Using the Theory of Planned Behaviour to Examine the Relationship between Attitudes and Behaviour." Journal of Environmental Psychology 43: 1-12.

Morris, SS, Calogero Carletto, John Hoddinott and LM Christiaensen. 2000. "Validity of Rapid Estimates of Household Wealth and Income for Health Surveys in Rural Africa." Journal of Epidemiology \& Community Health 54 (5): 381-87.

Moser, Caroline and Andrew Felton. 2007. "The Construction of an Asset Index Measuring Asset Accumulation in Ecuador Caroline Moser and Andrew Felton CPRC Working Paper 87 ISBN 1-90404986-9." Development.

Peterson, JFR Kwesiga, S Franzel, D Phiri and C Gladwin. 2004. "Improved Fallows in Eastern Zambia BT - Green Manure/Cover Crop Systems of Smallholder Farmers: Experiences from Tropical and Subtropical Regions." In , edited by Marjatta Eilittä, Joseph Mureithi, and Rolf Derpsch, 128-52. Dordrecht: Springer Netherlands.

Schochet, Peter Z and Hanley S Chiang. 2011. "Estimation and Identification of the Complier Average Causal Effect Parameter in Education RCTs." Journal of Educational and Behavioral Statistics 36 (3): 307-45. 
Sileshi, G and PL Mafongoya. 2006. "Long-Term Effects of Improved Legume Fallows on Soil Invertebrate Macrofauna and Maize Yield in Eastern Zambia." Agriculture, Ecosystems and Environment 115 (1-4): 69-78.

Sileshi, Gudeta, Festus K Akinnifesi, Oluyede C Ajayi and Frank Place. 2008. "Meta-Analysis of Maize Yield Response to Woody and Herbaceous Legumes in Sub-Saharan Africa." Plant and Soil 307 (1-2): 1-19.

Sileshi, Gudeta W, and Festus K Akinnifesi. 2017. "Comments on Coe Et Al. (2016)-'Loading the Dice in Favour of the Farmer ...'" Experimental Agriculture, no. 2016: 1-6.

Singal, Amit G, Peter DR Higgins and Akbar K Waljee. 2014. "A Primer on Effectiveness and Efficacy Trials." Clinical and Translational Gastroenterology 5 (2). Nature Publishing Group: e45.

Sovey, Allison J and Donald P Green. 2011. "Instrumental Variables Estimation in Political Science: A Readers' Guide." American Journal of Political Science 55 (1). Blackwell Publishing Inc: 188-200.

Spevacek, Anne Marie. 2011. “Acacia ( Faidherbia ) Albida." www.usaid.gov.

Tougiani, Abasse, Chaibou Guero and Tony Rinaudo. 2008. "Community Mobilisation for Improved Livelihoods through Tree Crop Management in Niger." GeoJournal 74 (5): 377.

Verardi, V and C Croux. 2009. "Robust Regression in Stata." Stata Journal 9 (3). College Station, TX: Stata Press: 439-53.

White, H. 2010. "A Contribution to Current Debates in Impact Evaluation." Evaluation 16 (2): 153-64.

White, Howard. 2009. "Theory-Based Impact Evaluation: Principles and Practice," Journal of Development Effectiveness 1(3) 271-284.

Zvoch, Keith. 2009. "Treatment Fidelity in Multisite Evaluation." American Journal of Evaluation 30 (1). SAGE Publications: 44-61. 


\section{Annex 1: AFSP II Endline Sampling Strategy}

- AFSP II's main impact assessment strategy involves comparing Year 1 and Year 3 programme participants.

- The Year 3 programme participants should come from newer villages targeted by the programme. We cannot compare Year 1 and Year 3 participants from the same villages, because the former are likely to be more active that the latter. In other words, we would be comparing more innovative, risk taking farmers with laggard farmers, which would lead to biased impact estimates.

- Given this, the approach is as follows: villages with relatively high numbers of Year 1 participants will be identified-about 3-5 per EPA. Efforts will then be made to identify villages with high numbers of Year 3 participants where most if not all of the farmers in these villages started participating at this time. These Year 3 villages should be similar to the Year 1 villages in the following respects:

- fall within the same political, economic, and sociocultural setting;

- have similar baseline poverty levels;

- have similar access to major urban centers, markets, roads and relation infrastructure, and basic services;

- have similar agro-ecological features and biophysical characteristics (e.g. elevation, slope, soil, and rainfall patterns);

- have similar population densities and land use and settlement patterns.

- Have similar presence of NGO and development programs

- The study will not be able to obtain representative statistics from the Year 1 and Year 3 farmers. There are too many villages and too many villages with small numbers of participants, which would make this cost prohibitive. More emphasis will be made on ensuring that the comparison of Year 1 and Year 3 farmers is fair, i.e. ensuring the study possesses high internal validity.

- The sample size for each of the three districts-Dedza, Mzimba, and Thyolo-is 400, 200 Year $1 \mathrm{~s}$ and 200 Year $3 \mathrm{~s}$ in each district. Given that about $50 \%$ of the programme participants are women, 100 male and 100 female participants will be interviewed in each district and for each of the two years.

- 3-5 villages where there are relatively high numbers of Year 1 male and female participants in each EPA will be identified and matched with Year 3 villages as described above. The sample of 200 Year 1 and 200 Year 3 programme participants will be divided in proportionately to the numbers of participants coming from these villages.

- Anna Maria is currently working on possible Year 1 and Year 3 villages, which can be discussed by the team. However, local stakeholders in the districts will need to help us to select comparable Year 1 and Year 3 villages in each district.

\section{Procedure for village and farmers selection}

1. Together with partners identify:

a. Three villages with high concentrations of female and male participants in the first year of program implementation (2012/2013)

b. Three villages that can be matched to the year one villages according to the criteria specified above. And that have started benefitting from the program in the third year of implementation (2014/2015). After complying with this criteria 
the villages selected will be those with the highest concentration of female and male farmers participants

2. Try to get the number of program registered participants through ICRAF database of other sources of information (e.g. records from partners).

3. Input the numbers in the excel template provided that will have automatically calculate the number of farmers to be included in the sample.

4. To select the names in the sample there are two alternatives:

a. Alternative A: you have the list of names in an excel file.

i. Take the list of participants for each year and create one column with a random number using the excel formula: +RAND()

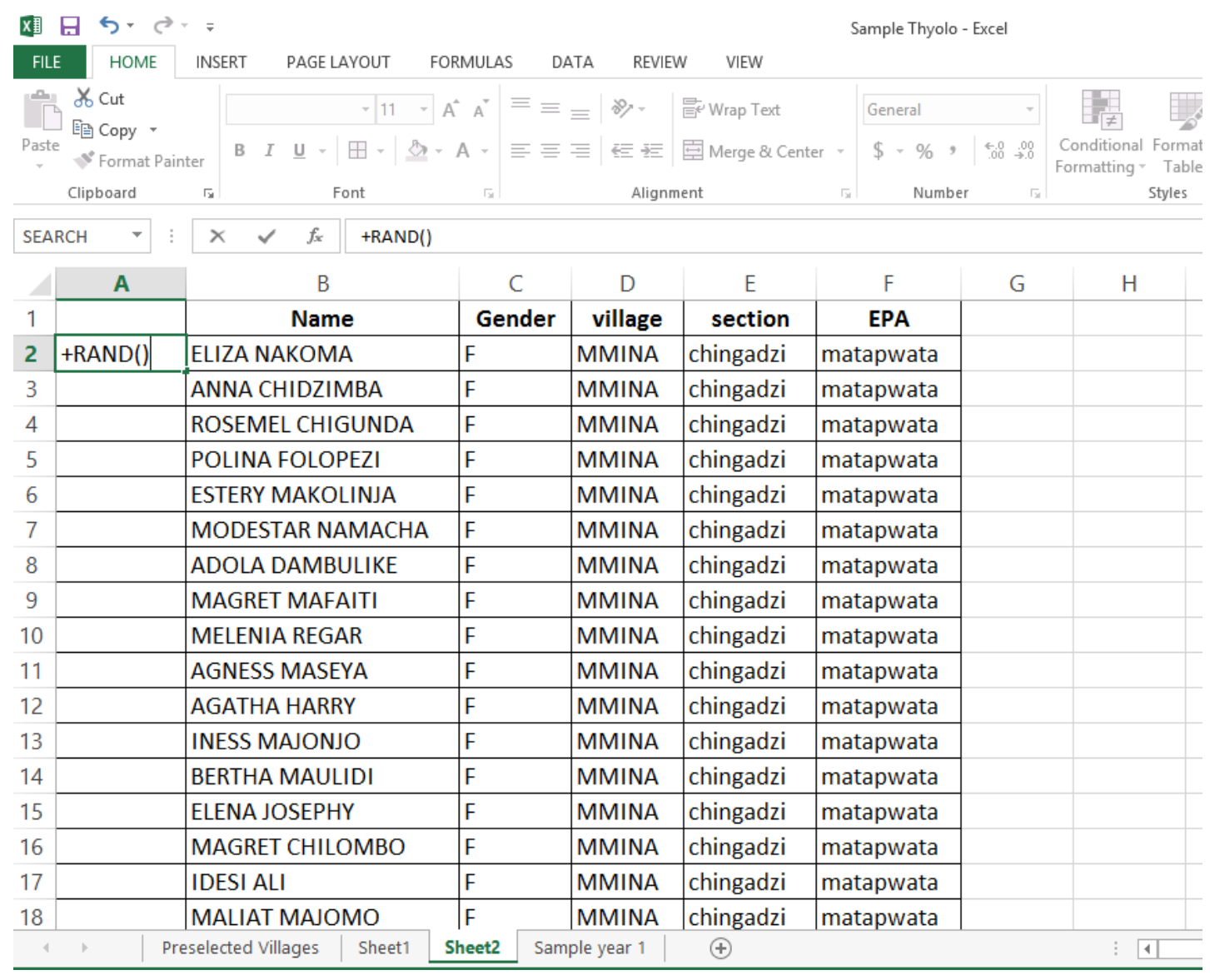

ii. Copy and paste the formula next to the complete list of participants. 


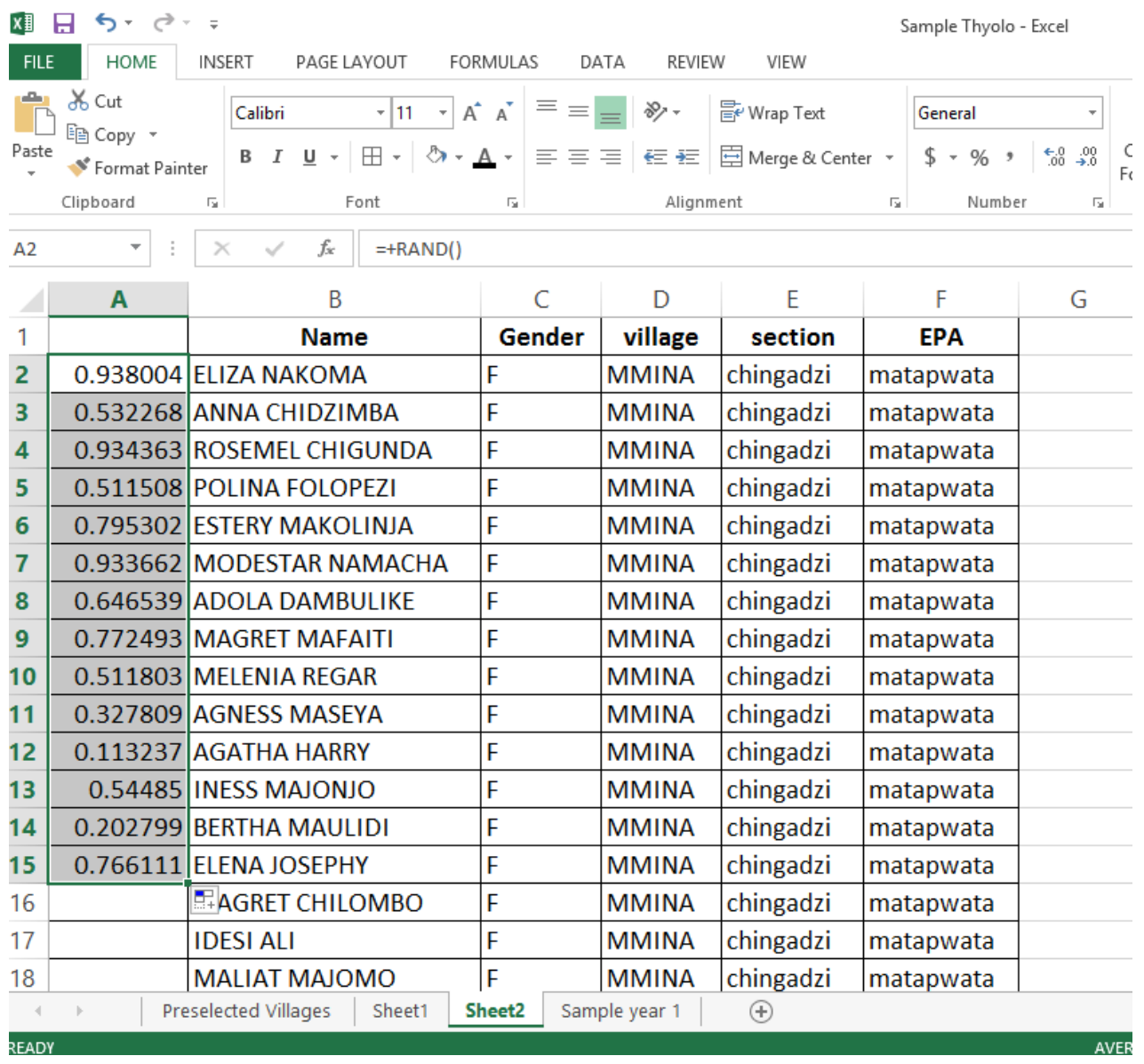

iii. Copy the numbers obtained as a result of applying the formula and paste as values in the same location

\begin{tabular}{l|l|l|l|l|l|l|l|}
\hline & \\
\hline
\end{tabular}




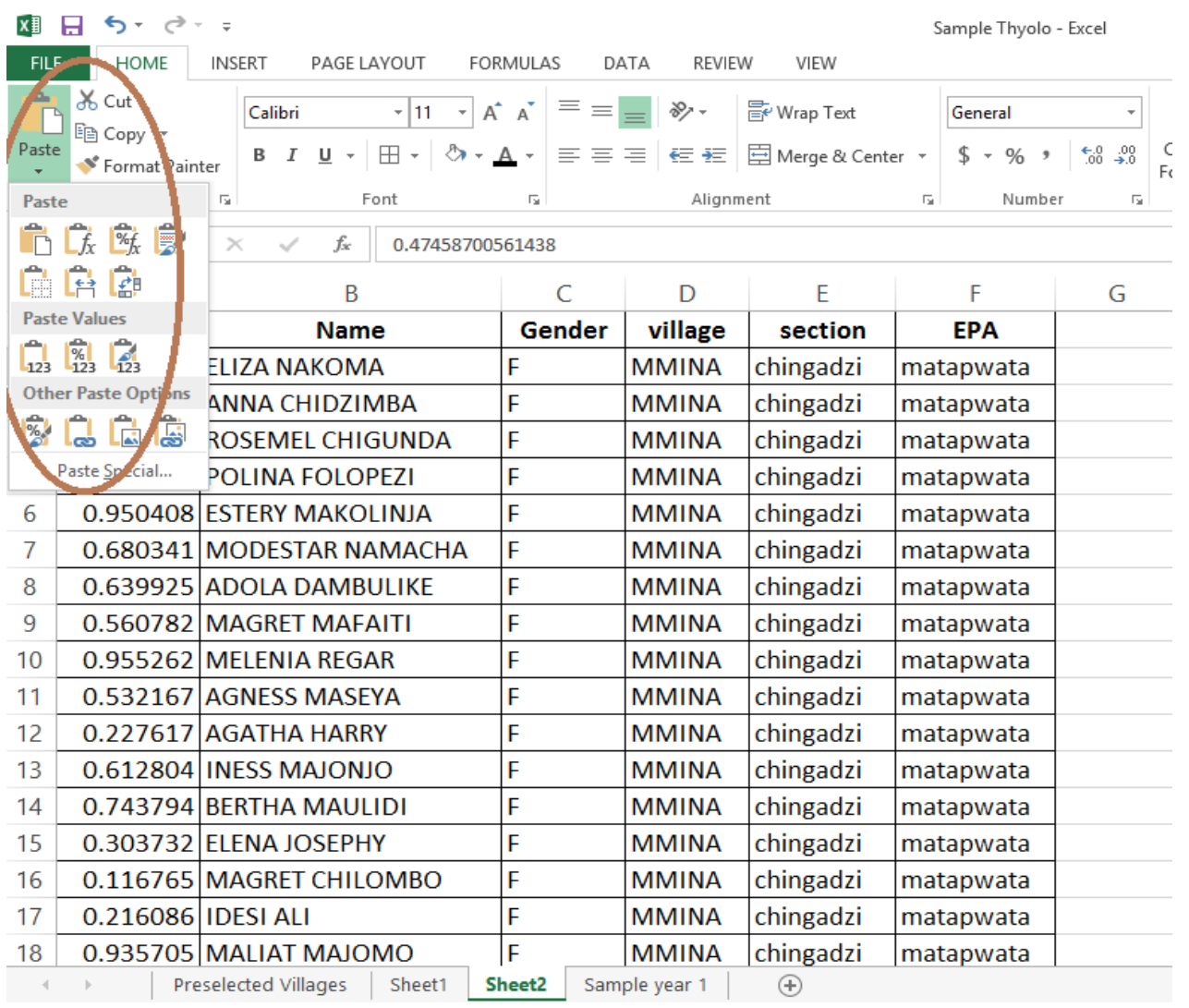

iv. Sort the list from the smallest to the largest value according to the random number assigned

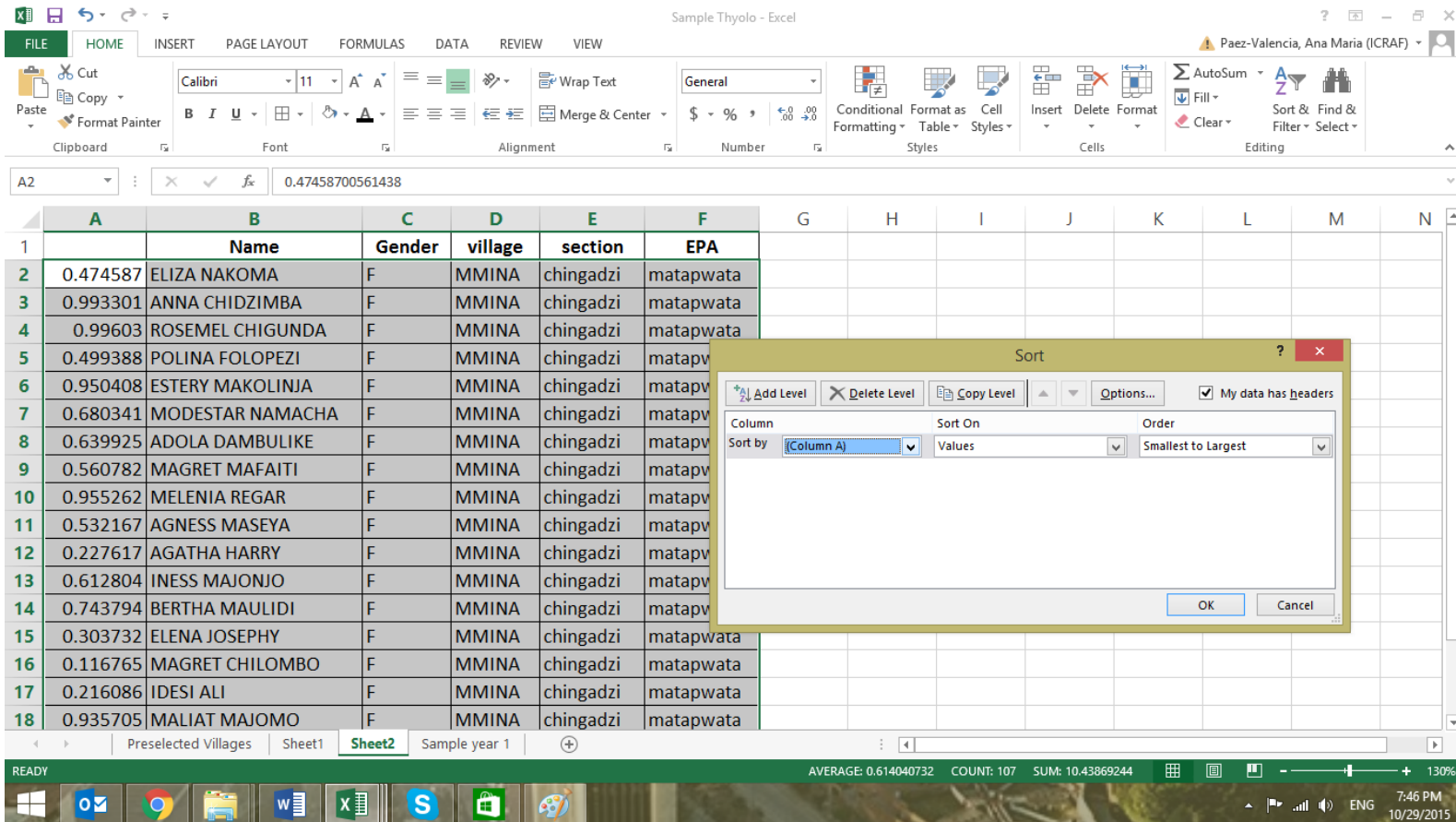

i. After the list is organized according to the random number you can proceed to select the names in order until you complete your sample size. In the example below the sample size for this particular village is 8 and the names highlighted in yellow are the farmers sampled. 


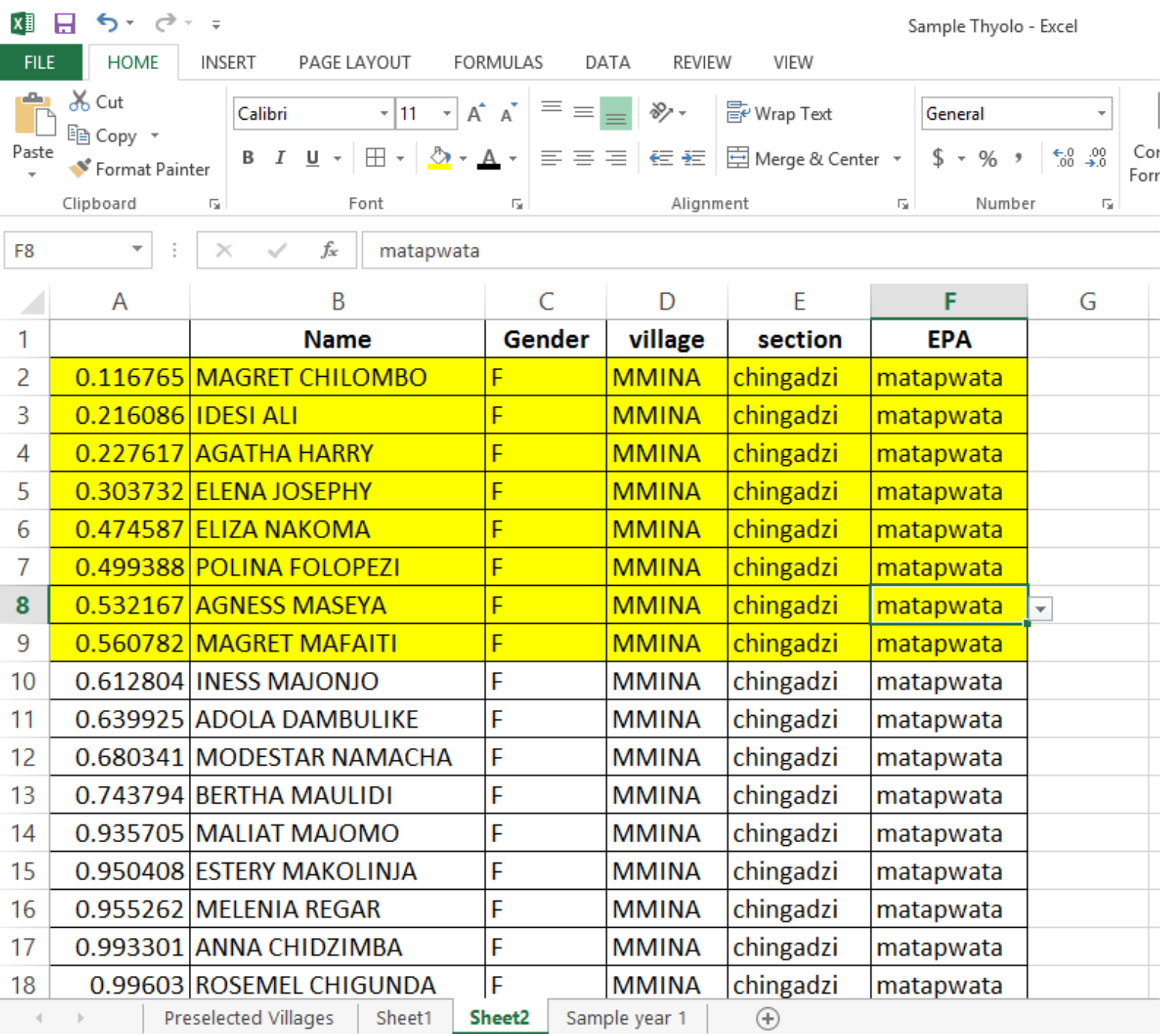

b. Alternative B: If you only find a hard copy list of the registered participants.

i. Separate the female and male participants.

ii. Calculate the sampling interval by dividing the total number of participants by the Sample size. If the result is a decimal this number will need to be rounded down.

iii. Select a random number that is less than or equal to the sample interval. This can be done by putting numbers in a bag and picking one. The selected number will be the starting sampling point. The name in that position in the list is the first name in the sample. The rest of the names will be selected by counting positions according to the sampling interval.

Example:

Total No. of participants $=100$

Sample size $=30$

Sampling interval $=3.33$ : rounded down to: 3 
We take three little pieces of paper and write the numbers 1,2 and 3. The papers are put in a bag and one of them is randomly selected.

If, for example, the paper with number 2 is selected, the name in the second row of the list will be the first name in our sample. Following the sampling interval the next name in our sample will be the person in the fifth position, and so on, as shown in the image bellow:

\begin{tabular}{|r|l|l|l|l|l|}
\cline { 2 - 6 } \multicolumn{1}{|c|}{ Name } & Gender & village & section & EPA \\
\hline 1 & ELIZA NAKOMA & F & MMINA & chingadzi & matapwata \\
\hline 2 & ANNA CHIDZIMBA & F & MMINA & chingadzi & matapwata \\
\hline 3 & ROSEMEL CHIGUNDA & F & MMINA & chingadzi & matapwata \\
\hline 4 & POLINA FOLOPEZI & F & MMINA & chingadzi & matapwata \\
\hline 5 & ESTERY MAKOLINJA & F & MMINA & chingadzi & matapwata \\
\hline 6 & MODESTAR NAMACHA & F & MMINA & chingadzi & matapwata \\
\hline 7 & ADOLA DAMBULIKE & F & MMINA & chingadzi & matapwata \\
\hline 8 & MAGRET MAFAITI & F & MMINA & chingadzi & matapwata \\
\hline 9 & MELENIA REGAR & F & MMINA & chingadzi & matapwata \\
\hline 10 & AGNESS MASEYA & F & MMINA & chingadzi & matapwata \\
\hline 11 & AGATHA HARRY & F & MMINA & chingadzi & matapwata \\
\hline 12 & INESS MAJONJO & F & MMINA & chingadzi & matapwata \\
\hline 13 & BERTHA MAULIDI & F & MMINA & chingadzi & matapwata \\
\hline 14 & ELENA JOSEPHY & F & MMINA & chingadzi & matapwata \\
\hline 15 & MAGRET CHILOMBO & F & MMINA & chingadzi & matapwata \\
\hline 16 & IDESI ALI & F & MMINA & chingadzi & matapwata \\
\hline 17 & MALIAT MAJOMO & F & MMINA & chingadzi & matapwata \\
\hline
\end{tabular}


Annex 2: Fertilizer Tree Biomass Incorporation Tables

TABLE A21. Incorporation of Biomass into Soil Prior to Maize Planting, Overall \& by Gender

\begin{tabular}{|c|c|c|c|c|c|c|c|c|c|}
\hline \multirow[b]{2}{*}{ Variable } & \multicolumn{3}{|c|}{ Overall } & \multicolumn{3}{|c|}{ Female } & \multicolumn{3}{|c|}{ Male } \\
\hline & $Y 1 s$ & $Y 3 s$ & dif. & $Y 1 s$ & $Y 3 s$ & dif. & $Y 1 s$ & $Y 3 s$ & dif. \\
\hline \multicolumn{10}{|l|}{ 2014/15 Farming Season } \\
\hline Any biomass & 0.79 & 0.72 & $\begin{array}{c}0.067^{*} \\
(1.90)\end{array}$ & 0.77 & 0.69 & $\begin{array}{l}0.081 \\
(1.63)\end{array}$ & 0.82 & 0.77 & $\begin{array}{l}0.055 \\
(1.13)\end{array}$ \\
\hline Biomass from fertilizer trees & 0.31 & 0.27 & $\begin{array}{l}0.042 \\
(1.11)\end{array}$ & 0.30 & 0.21 & $\begin{array}{l}0.080 \\
(1.61)\end{array}$ & 0.34 & 0.34 & $\begin{array}{c}0.0026 \\
(0.045)\end{array}$ \\
\hline Maize stover & 0.62 & 0.56 & $\begin{array}{l}0.062 \\
(1.53)\end{array}$ & 0.63 & 0.50 & $\begin{array}{c}0.12 * * \\
(2.19)\end{array}$ & 0.62 & 0.63 & $\begin{array}{l}-0.0055 \\
(-0.092)\end{array}$ \\
\hline Groundnut forage & 0.07 & 0.07 & $\begin{array}{c}0.0021 \\
(0.10)\end{array}$ & 0.07 & 0.07 & $\begin{array}{c}-0.0039 \\
(-0.13)\end{array}$ & 0.07 & 0.07 & $\begin{array}{c}0.0093 \\
(0.29)\end{array}$ \\
\hline Tephrosia leaves & 0.17 & 0.07 & $\begin{array}{c}0.095^{* * *} \\
(3.35)\end{array}$ & 0.17 & 0.05 & $\begin{array}{c}0.12 * * * \\
(3.15)\end{array}$ & 0.17 & 0.10 & $\begin{array}{l}0.070 \\
(1.61)\end{array}$ \\
\hline Gliricidia leaves & 0.07 & 0.04 & $\begin{array}{c}0.033^{*} \\
(1.66)\end{array}$ & 0.07 & 0.02 & $\begin{array}{c}0.050 * * \\
(2.04)\end{array}$ & 0.08 & 0.07 & $\begin{array}{l}0.015 \\
(0.47)\end{array}$ \\
\hline Faidherbia leaves & 0.06 & 0.06 & $\begin{array}{c}-0.0040 \\
(-0.21)\end{array}$ & 0.07 & 0.03 & $\begin{array}{l}0.033 \\
(1.29)\end{array}$ & 0.05 & 0.09 & $\begin{array}{l}-0.047 \\
(-1.58)\end{array}$ \\
\hline Pigeon pea leaves & 0.21 & 0.18 & $\begin{array}{l}0.027 \\
(0.82)\end{array}$ & 0.19 & 0.16 & $\begin{array}{l}0.028 \\
(0.65)\end{array}$ & 0.24 & 0.21 & $\begin{array}{l}0.030 \\
(0.59)\end{array}$ \\
\hline Sesbania leaves & 0.01 & 0.02 & $\begin{array}{c}-0.0076 \\
(-0.81)\end{array}$ & 0.01 & 0.02 & $\begin{array}{c}-0.0077 \\
(-0.64)\end{array}$ & 0.01 & 0.02 & $\begin{array}{c}-0.0072 \\
(-0.49)\end{array}$ \\
\hline Compost or animal manure & 0.10 & 0.09 & $\begin{array}{c}0.0052 \\
(0.21)\end{array}$ & 0.10 & 0.09 & $\begin{array}{l}0.010 \\
(0.31)\end{array}$ & 0.09 & 0.09 & $\begin{array}{l}-0.0015 \\
(-0.042)\end{array}$ \\
\hline Other & 0.06 & 0.07 & $\begin{array}{l}-0.015 \\
(-0.72)\end{array}$ & 0.06 & 0.09 & $\begin{array}{l}-0.029 \\
(-1.01)\end{array}$ & 0.06 & 0.06 & $\begin{array}{c}0.0014 \\
(0.049)\end{array}$ \\
\hline Observations & 401 & 228 & 629 & 227 & 121 & 348 & 174 & 107 & 281 \\
\hline \multicolumn{10}{|l|}{$\begin{array}{l}\text { Proportion of field covered by } \\
\text { fertilizer tree incorporation }\end{array}$} \\
\hline Less than half & 0.14 & 0.16 & $\begin{array}{l}-0.018 \\
(-0.33)\end{array}$ & 0.15 & 0.15 & $\begin{array}{l}-0.0046 \\
(-0.056)\end{array}$ & 0.14 & 0.17 & $\begin{array}{l}-0.031 \\
(-0.41)\end{array}$ \\
\hline About half & 0.20 & 0.24 & $\begin{array}{l}-0.044 \\
(-0.69)\end{array}$ & 0.27 & 0.23 & $\begin{array}{l}0.038 \\
(0.37)\end{array}$ & 0.12 & 0.25 & $\begin{array}{l}-0.13^{*} \\
(-1.66)\end{array}$ \\
\hline More than half by not all & 0.09 & 0.10 & $\begin{array}{c}-0.0095 \\
(-0.21)\end{array}$ & 0.09 & 0.08 & $\begin{array}{l}0.013 \\
(0.19)\end{array}$ & 0.08 & 0.11 & $\begin{array}{l}-0.026 \\
(-0.43)\end{array}$ \\
\hline All & 0.57 & 0.50 & $\begin{array}{l}0.071 \\
(0.93)\end{array}$ & 0.49 & 0.54 & $\begin{array}{l}-0.046 \\
(-0.40)\end{array}$ & 0.66 & 0.47 & $\begin{array}{l}0.19^{*} \\
(1.81)\end{array}$ \\
\hline Observations & 126 & 62 & 188 & 67 & 26 & 93 & 59 & 36 & 95 \\
\hline \multicolumn{10}{|l|}{$\begin{array}{l}\text { Quantity of biomass from } \\
\text { fertilizer tree incorporation }\end{array}$} \\
\hline Little & 0.22 & 0.44 & $\begin{array}{c}-0.22 * * * \\
(-3.10)\end{array}$ & 0.22 & 0.35 & $\begin{array}{c}-0.12 \\
(-1.21)\end{array}$ & 0.22 & 0.51 & $\begin{array}{c}-0.29 * * * \\
(-2.93)\end{array}$ \\
\hline Moderate & 0.21 & 0.25 & $\begin{array}{l}-0.040 \\
(-0.61)\end{array}$ & 0.22 & 0.31 & $\begin{array}{l}-0.084 \\
(-0.84)\end{array}$ & 0.19 & 0.20 & $\begin{array}{l}-0.014 \\
(-0.16)\end{array}$ \\
\hline High & 0.57 & 0.31 & $\begin{array}{c}0.26^{* * *} \\
(3.33)\end{array}$ & 0.55 & 0.35 & $\begin{array}{l}0.21^{*} \\
(1.78)\end{array}$ & 0.59 & 0.29 & $\begin{array}{c}0.31 * * * \\
(2.89)\end{array}$ \\
\hline Observations & 126 & 61 & 187 & 67 & 26 & 93 & 59 & 35 & 94 \\
\hline \multicolumn{10}{|l|}{ 2013/14 Farming Season } \\
\hline Biomass from fertilizer trees & 0.24 & 0.12 & $\begin{array}{l}0.12 * * * \\
(3.67)\end{array}$ & 0.22 & 0.11 & $\begin{array}{l}0.11^{* *} \\
(2.43)\end{array}$ & 0.27 & 0.13 & $\begin{array}{c}0.14 * * * \\
(2.82)\end{array}$ \\
\hline Observations & 402 & 229 & 631 & 227 & 122 & 349 & 175 & 107 & 282 \\
\hline \multicolumn{10}{|l|}{$\begin{array}{l}\text { 2013/14 \& 2014/15 Farming } \\
\text { Seasons }\end{array}$} \\
\hline $\begin{array}{l}\text { Biomass from FT previous } 2 \text { years } \\
\text { in moderate to significant quantity } \\
\text { on most or all of maize field }\end{array}$ & 0.14 & 0.06 & $\begin{array}{l}0.085 * * * \\
\quad(3.26)\end{array}$ & 0.11 & 0.05 & $\begin{array}{c}0.061^{*} \\
(1.89)\end{array}$ & 0.18 & 0.07 & $\begin{array}{l}0.12 * * * \\
(2.79)\end{array}$ \\
\hline Observations & 401 & 228 & 629 & 227 & 121 & 348 & 174 & 107 & 281 \\
\hline
\end{tabular}

$z$ statistics in parentheses

$* \mathrm{p}<0.1, * * \mathrm{p}<0.05, * * * \mathrm{p}<0.01$ 
TABLE A22. Incorporation of Biomass into Soil Prior to Maize Planting by District

\begin{tabular}{|c|c|c|c|c|c|c|c|c|c|}
\hline \multirow[b]{2}{*}{ Variable } & \multicolumn{3}{|c|}{ Mzimba } & \multicolumn{3}{|c|}{ Dedza } & \multicolumn{3}{|c|}{ Thyolo } \\
\hline & $Y 1 s$ & $Y 3 s$ & dif. & $Y 1 s$ & $Y 3 s$ & dif. & $Y 1 s$ & $Y 3 s$ & dif. \\
\hline \multicolumn{10}{|l|}{ 2014/15 Farming Season } \\
\hline Any biomass & 0.75 & 0.62 & $\begin{array}{c}0.13 * * \\
(1.97)\end{array}$ & 0.81 & 0.76 & $\begin{array}{l}0.044 \\
(0.79)\end{array}$ & 0.81 & 0.78 & $\begin{array}{l}0.033 \\
(0.56)\end{array}$ \\
\hline Biomass from fertilizer trees & 0.22 & 0.18 & $\begin{array}{l}0.035 \\
(0.59)\end{array}$ & 0.27 & 0.19 & $\begin{array}{l}0.084 \\
(1.42)\end{array}$ & 0.45 & 0.46 & $\begin{array}{l}-0.0038 \\
(-0.052)\end{array}$ \\
\hline Maize stover & 0.58 & 0.45 & $\begin{array}{l}0.13^{*} \\
(1.75)\end{array}$ & 0.62 & 0.55 & $\begin{array}{l}0.065 \\
(0.95)\end{array}$ & 0.67 & 0.68 & $\begin{array}{l}-0.0063 \\
(-0.092)\end{array}$ \\
\hline Groundnut forage & 0.06 & 0.07 & $\begin{array}{l}-0.010 \\
(-0.29)\end{array}$ & 0.14 & 0.13 & $\begin{array}{l}0.010 \\
(0.22)\end{array}$ & 0.02 & 0.00 & $\begin{array}{l}0.015 \\
(1.05)\end{array}$ \\
\hline Tephrosia leaves & 0.18 & 0.04 & $\begin{array}{c}0.14 * * * \\
(2.77)\end{array}$ & 0.13 & 0.05 & $\begin{array}{c}0.085 * * \\
(2.06)\end{array}$ & 0.20 & 0.14 & $\begin{array}{l}0.058 \\
(1.04)\end{array}$ \\
\hline Gliricidia leaves & 0.05 & 0.03 & $\begin{array}{l}0.017 \\
(0.59)\end{array}$ & 0.05 & 0.04 & $\begin{array}{l}0.016 \\
(0.56)\end{array}$ & 0.12 & 0.06 & $\begin{array}{l}0.066 \\
(1.51)\end{array}$ \\
\hline Faidherbia leaves & 0.02 & 0.08 & $\begin{array}{c}-0.062 * * \\
(-2.05)\end{array}$ & 0.12 & 0.09 & $\begin{array}{l}0.024 \\
(0.55)\end{array}$ & 0.03 & 0.00 & $\begin{array}{l}0.030 \\
(1.49)\end{array}$ \\
\hline Pigeon pea leaves & 0.13 & 0.10 & $\begin{array}{l}0.029 \\
(0.62)\end{array}$ & 0.12 & 0.05 & $\begin{array}{c}0.071 * \\
(1.78)\end{array}$ & 0.38 & 0.42 & $\begin{array}{l}-0.038 \\
(-0.53)\end{array}$ \\
\hline Sesbania leaves & 0.00 & 0.03 & $\begin{array}{l}-0.028 * \\
(-1.95)\end{array}$ & 0.02 & 0.02 & $\begin{array}{l}-0.0015 \\
(-0.072)\end{array}$ & 0.01 & 0.00 & $\begin{array}{c}0.0076 \\
(0.74)\end{array}$ \\
\hline Compost or animal manure & 0.14 & 0.08 & $\begin{array}{l}0.058 \\
(1.21)\end{array}$ & 0.06 & 0.11 & $\begin{array}{l}-0.047 \\
(-1.28)\end{array}$ & 0.09 & 0.08 & $\begin{array}{c}0.0076 \\
(0.18)\end{array}$ \\
\hline Other & 0.05 & 0.11 & $\begin{array}{c}-0.068^{*} \\
(-1.82)\end{array}$ & 0.12 & 0.07 & $\begin{array}{l}0.047 \\
(1.14)\end{array}$ & 0.02 & 0.04 & $\begin{array}{l}-0.027 \\
(-1.17)\end{array}$ \\
\hline Observations & 133 & 71 & 204 & 136 & 85 & 221 & 132 & 72 & 204 \\
\hline \multicolumn{10}{|l|}{$\begin{array}{l}\text { Proportion of field covered by } \\
\text { fertilizer tree incorporation }\end{array}$} \\
\hline Less than half & 0.14 & 0.23 & $\begin{array}{l}-0.093 \\
(-0.75)\end{array}$ & 0.22 & 0.19 & $\begin{array}{l}0.029 \\
(0.24)\end{array}$ & 0.10 & 0.12 & $\begin{array}{l}-0.021 \\
(-0.32)\end{array}$ \\
\hline About half & 0.28 & 0.38 & $\begin{array}{c}-0.11 \\
(-0.70)\end{array}$ & 0.24 & 0.19 & $\begin{array}{l}0.056 \\
(0.45)\end{array}$ & 0.13 & 0.21 & $\begin{array}{l}-0.079 \\
(-0.99)\end{array}$ \\
\hline More than half by not all & 0.07 & 0.08 & $\begin{array}{l}-0.0080 \\
(-0.093)\end{array}$ & 0.19 & 0.00 & $\begin{array}{l}0.19^{*} \\
(1.87)\end{array}$ & 0.03 & 0.15 & $\begin{array}{c}-0.12 * * \\
(-2.07)\end{array}$ \\
\hline All & 0.52 & 0.31 & $\begin{array}{c}0.21 \\
(1.26)\end{array}$ & 0.35 & 0.63 & $\begin{array}{l}-0.27^{*} \\
(-1.85)\end{array}$ & 0.73 & 0.52 & $\begin{array}{c}0.22 * * \\
(2.12)\end{array}$ \\
\hline Observations & 29 & 13 & 42 & 37 & 16 & 53 & 60 & 33 & 93 \\
\hline \multicolumn{10}{|l|}{$\begin{array}{l}\text { Quantity of biomass from } \\
\text { fertilizer tree incorporation }\end{array}$} \\
\hline Little & 0.21 & 0.58 & $\begin{array}{l}-0.38 * * \\
(-2.36)\end{array}$ & 0.30 & 0.75 & $\begin{array}{c}-0.45^{* * *} \\
(-3.05)\end{array}$ & 0.18 & 0.24 & $\begin{array}{l}-0.059 \\
(-0.68)\end{array}$ \\
\hline Moderate & 0.07 & 0.25 & $\begin{array}{l}-0.18 \\
(-1.61)\end{array}$ & 0.16 & 0.13 & $\begin{array}{l}0.037 \\
(0.35)\end{array}$ & 0.30 & 0.30 & $\begin{array}{l}-0.0030 \\
(-0.030)\end{array}$ \\
\hline High & 0.72 & 0.17 & $\begin{array}{c}0.56 * * * \\
(3.27)\end{array}$ & 0.54 & 0.13 & $\begin{array}{c}0.42 * * * \\
(2.82)\end{array}$ & 0.52 & 0.45 & $\begin{array}{l}0.062 \\
(0.57)\end{array}$ \\
\hline Observations & 29 & 12 & 41 & 37 & 16 & 53 & 60 & 33 & 93 \\
\hline \multicolumn{10}{|l|}{ 2013/14 Farming Season } \\
\hline Biomass from fertilizer trees & 0.18 & 0.03 & $\begin{array}{c}0.15 * * * \\
(3.09)\end{array}$ & 0.24 & 0.07 & $\begin{array}{c}0.17 * * * \\
(3.26)\end{array}$ & 0.31 & 0.27 & $\begin{array}{l}0.037 \\
(0.55)\end{array}$ \\
\hline Observations & 134 & 71 & 205 & 136 & 85 & 221 & 132 & 73 & 205 \\
\hline \multicolumn{10}{|l|}{$\begin{array}{l}\text { 2013/14 \& 2014/15 Farming } \\
\text { Seasons }\end{array}$} \\
\hline $\begin{array}{l}\text { Biomass from FT previous } 2 \text { years } \\
\text { in moderate to significant quantity } \\
\text { on most or all of maize field }\end{array}$ & 0.10 & 0.01 & $\begin{array}{c}0.084 * * \\
(2.25)\end{array}$ & 0.12 & 0.04 & $\begin{array}{c}0.082 * * \\
(2.12)\end{array}$ & 0.21 & 0.13 & $\begin{array}{l}0.087 \\
(1.54)\end{array}$ \\
\hline Observations & 133 & 71 & 204 & 136 & 85 & 221 & 132 & 72 & 204 \\
\hline
\end{tabular}

$z$ statistics in parentheses

$* \mathrm{p}<0.1, * * \mathrm{p}<0.05, * * * \mathrm{p}<0.01$ 
TABLE A23: Reasons of Not Incorporating Fertilization Tree Biomass into Soil Prior to Maize Planting by District

\begin{tabular}{|c|c|c|c|c|c|c|c|c|c|}
\hline \multirow[b]{2}{*}{ Variable } & \multicolumn{3}{|c|}{ Mzimba } & \multicolumn{3}{|c|}{ Dedza } & \multicolumn{3}{|c|}{ Thyolo } \\
\hline & $Y 1 s$ & $Y 3 s$ & dif. & $Y 1 s$ & $Y 3 s$ & dif. & $Y 1 s$ & $Y 3 s$ & dif. \\
\hline \multicolumn{10}{|l|}{ 2014/15 Farming Season } \\
\hline $\begin{array}{l}\text { Did not intercrop fertilizer trees in } \\
2013 / 14\end{array}$ & 0.64 & 0.90 & $\begin{array}{c}-0.26 * * * \\
(-3.56)\end{array}$ & 0.64 & 0.97 & $\begin{array}{c}-0.33 * * * \\
(-5.10)\end{array}$ & 0.64 & 0.80 & $\begin{array}{l}-0.16^{*} \\
(-1.78)\end{array}$ \\
\hline $\begin{array}{l}\text { Intercropped but trees did not } \\
\text { mature well }\end{array}$ & 0.10 & 0.03 & $\begin{array}{l}0.061 \\
(1.42)\end{array}$ & 0.07 & 0.03 & $\begin{array}{l}0.042 \\
(1.18)\end{array}$ & 0.08 & 0.05 & $\begin{array}{l}0.033 \\
(0.66)\end{array}$ \\
\hline $\begin{array}{l}\text { Intercropped with moderate to } \\
\text { good results but no incorporation }\end{array}$ & 0.27 & 0.07 & $\begin{array}{c}0.20 * * * \\
(3.04)\end{array}$ & 0.27 & 0.00 & $\begin{array}{c}0.27 * * * \\
(4.74)\end{array}$ & 0.26 & 0.15 & $\begin{array}{c}0.11 \\
(1.39)\end{array}$ \\
\hline Observations & 105 & 58 & 163 & 99 & 69 & 168 & 72 & 40 & 112 \\
\hline \multicolumn{10}{|l|}{ 2013/14 Farming Season } \\
\hline $\begin{array}{l}\text { Did not intercrop fertilizer trees in } \\
2012 / 13\end{array}$ & 0.48 & 1.00 & $\begin{array}{c}-0.52 * * * \\
(-7.24)\end{array}$ & 0.56 & 0.97 & $\begin{array}{c}-0.41 * * * \\
(-6.29)\end{array}$ & 0.55 & 0.77 & $\begin{array}{c}-0.22 * * * \\
(-2.69)\end{array}$ \\
\hline $\begin{array}{l}\text { Intercropped but trees did not } \\
\text { mature well }\end{array}$ & 0.11 & 0.00 & $\begin{array}{l}0.11 * * * \\
(2.84)\end{array}$ & 0.15 & 0.00 & $\begin{array}{l}0.15 * * * \\
(3.54)\end{array}$ & 0.12 & 0.02 & $\begin{array}{l}0.10^{* *} \\
(2.14)\end{array}$ \\
\hline $\begin{array}{l}\text { Intercropped with moderate to } \\
\text { good results but no incorporation }\end{array}$ & 0.41 & 0.00 & $\begin{array}{l}0.41 * * * \\
(6.14)\end{array}$ & 0.28 & 0.03 & $\begin{array}{c}0.26 * * * \\
(4.56)\end{array}$ & 0.33 & 0.21 & $\begin{array}{c}0.12 \\
(1.57)\end{array}$ \\
\hline Observations & 110 & 69 & 179 & 103 & 79 & 182 & 91 & 53 & 144 \\
\hline
\end{tabular}

$z$ statistics in parentheses

$* \mathrm{p}<0.1, * * \mathrm{p}<0.05, * * * \mathrm{p}<0.01$ 
Annex 3: Differential Effects Analysis Tables

TABLE A31: 2014/15 Maize Harvest Measures -Year 1s versus Year 3s, Differential Effects

\begin{tabular}{|c|c|c|c|c|c|c|}
\hline & $\begin{array}{c}\text { Kgs of } \\
\text { unshelled } \\
\text { maize }\end{array}$ & $\begin{array}{c}\text { Kgs of } \\
\text { unshelled } \\
\text { maize per } \\
\text { acre }\end{array}$ & $\begin{array}{c}\text { Kgs of } \\
\text { unshelled } \\
\text { maize per } \\
\text { acre (log) }\end{array}$ & $\begin{array}{c}\text { At least } \\
\text { 400kgs } \\
\text { unshelled } \\
\text { maize per } \\
\text { acre } \\
\end{array}$ & $\begin{array}{c}\text { Production } \\
\text { cost of } \\
\text { unshelled } \\
\text { maize per kg } \\
\text { (MKW) }\end{array}$ & $\begin{array}{c}\text { Production } \\
\text { cost of } \\
\text { unshelled } \\
\text { maize per kg } \\
\text { (log) } \\
\end{array}$ \\
\hline Original OLS coefficient & $\begin{array}{c}54.0 \\
(86.9)\end{array}$ & $\begin{array}{c}41.8 \\
(44.2)\end{array}$ & $\begin{array}{c}0.10 \\
(0.093)\end{array}$ & $\begin{array}{l}0.090 \\
(0.12)\end{array}$ & $\begin{array}{l}-3.02 \\
(6.88)\end{array}$ & $\begin{array}{l}-0.0036 \\
(0.029)\end{array}$ \\
\hline Observations & 618 & 617 & 609 & 617 & 615 & 615 \\
\hline \multicolumn{7}{|l|}{ By District } \\
\hline $\begin{array}{l}\text { Mzimba*treated } \\
\text { Coefficient }\end{array}$ & $\begin{array}{c}-83.2 \\
(177.9)\end{array}$ & $\begin{array}{c}34.8 \\
(89.7)\end{array}$ & $\begin{array}{c}0.21 \\
(0.15)\end{array}$ & $\begin{array}{l}0.37^{*} \\
(0.20)\end{array}$ & $\begin{array}{l}-2.65 \\
(12.4)\end{array}$ & $\begin{array}{c}0.030 \\
(0.053)\end{array}$ \\
\hline $\begin{array}{l}\text { Dedza_ } 1 * \text { treated } \\
\text { Coefficient }\end{array}$ & $\begin{array}{l}571.8 \\
(348.4)\end{array}$ & $\begin{array}{c}146.5 \\
(166.6)\end{array}$ & $\begin{array}{c}0.18 \\
(0.34)\end{array}$ & $\begin{array}{l}-0.34 \\
(0.34)\end{array}$ & $\begin{array}{l}-23.0 \\
(22.7)\end{array}$ & $\begin{array}{l}-0.077 \\
(0.082)\end{array}$ \\
\hline $\begin{array}{l}\text { Dedza_2*treated } \\
\text { Coefficient }\end{array}$ & $\begin{array}{c}69.6 \\
(143.1)\end{array}$ & $\begin{array}{c}36.7 \\
(62.7)\end{array}$ & $\begin{array}{l}-0.034 \\
(0.21)\end{array}$ & $\begin{array}{l}0.050 \\
(0.25)\end{array}$ & $\begin{array}{c}11.7 \\
(17.2)\end{array}$ & $\begin{array}{c}0.030 \\
(0.063)\end{array}$ \\
\hline $\begin{array}{l}\text { Thyolo*treated } \\
\text { Coefficient }\end{array}$ & $\begin{array}{c}31.1 \\
(93.1)\end{array}$ & $\begin{array}{c}21.1 \\
(62.8)\end{array}$ & $\begin{array}{l}0.057 \\
(0.15)\end{array}$ & $\begin{array}{l}-0.053 \\
(0.19)\end{array}$ & $\begin{array}{l}-7.40 \\
(8.08)\end{array}$ & $\begin{array}{l}-0.039 \\
(0.044)\end{array}$ \\
\hline \multicolumn{7}{|l|}{ Wald tests (F) } \\
\hline Mzimba vs. Dedza_1 & 2.80 & 0.34 & 0.00 & $3.20^{*}$ & 0.61 & 1.19 \\
\hline$p$-value & 0.09 & 0.56 & 0.94 & 0.07 & 0.44 & 0.27 \\
\hline Mzimba vs. Dedza_2 & 0.46 & 0.00 & 0.94 & 1.04 & 0.51 & 0.00 \\
\hline$p$-value & 0.50 & 0.99 & 0.33 & 0.31 & 0.47 & 1.00 \\
\hline Mzimba vs. Thyolo & 0.34 & 0.02 & 0.49 & 2.36 & 0.10 & 1.02 \\
\hline$p$-value & 0.56 & 0.90 & 0.48 & 0.12 & 0.75 & 0.31 \\
\hline Dedza_1 vs. Dedza_2 & 1.82 & 0.38 & 0.28 & 0.84 & 1.40 & 1.05 \\
\hline$p$-value & 0.18 & 0.54 & 0.59 & 0.36 & 0.24 & 0.31 \\
\hline Dedza_1 vs. Thyolo & 2.23 & 0.49 & 0.12 & 0.53 & 0.46 & 0.17 \\
\hline$p$-value & 0.14 & 0.49 & 0.73 & 0.47 & 0.50 & 0.68 \\
\hline Dedza_2 vs. Thyolo & 0.06 & 0.03 & 0.13 & 0.11 & 0.92 & 0.78 \\
\hline$p$-value & 0.81 & 0.85 & 0.72 & 0.74 & 0.34 & 0.38 \\
\hline \multicolumn{7}{|l|}{ By Gender ${ }^{24}$} \\
\hline $\begin{array}{l}\text { Female*treated } \\
\text { Coefficient }\end{array}$ & $\begin{array}{l}33.7 \\
(91.4)\end{array}$ & $\begin{array}{l}-16.4 \\
(51.8)\end{array}$ & $\begin{array}{l}0.032 \\
(0.14)\end{array}$ & $\begin{array}{l}-0.035 \\
(0.15)\end{array}$ & $\begin{array}{l}-20.4^{*} \\
(11.3)\end{array}$ & $\begin{array}{l}-0.064 \\
(0.043)\end{array}$ \\
\hline $\begin{array}{l}\text { Male*treated } \\
\text { Coefficient }\end{array}$ & $\begin{array}{c}131.9 \\
(157.1)\end{array}$ & $\begin{array}{l}137.3^{*} \\
(73.0)\end{array}$ & $\begin{array}{l}0.24^{*} \\
(0.12)\end{array}$ & $\begin{array}{c}0.28 \\
(0.17)\end{array}$ & $\begin{array}{l}18.7^{*} \\
(9.58)\end{array}$ & $\begin{array}{l}0.077^{*} \\
(0.042)\end{array}$ \\
\hline \multicolumn{7}{|l|}{ Wald test (F) } \\
\hline Male vs. Female & 0.30 & $3.10^{*}$ & 1.26 & 1.97 & $6.15^{* *}$ & $5.32 * *$ \\
\hline$p$-value & 0.58 & 0.08 & 0.26 & 0.16 & 0.01 & 0.02 \\
\hline \multicolumn{7}{|c|}{ By Baseline Wealth Status } \\
\hline $\begin{array}{l}\text { Rich*treated } \\
\text { Coefficient }\end{array}$ & $\begin{array}{c}68.0 \\
(159.2)\end{array}$ & $\begin{array}{c}67.8 \\
(75.5)\end{array}$ & $\begin{array}{l}0.25^{*} \\
(0.13)\end{array}$ & $\begin{array}{c}0.17 \\
(0.16)\end{array}$ & $\begin{array}{l}-0.27 \\
(9.02)\end{array}$ & $\begin{array}{c}0.029 \\
(0.042)\end{array}$ \\
\hline
\end{tabular}

${ }^{24}$ Statistically significant differential effect for production cost is driven by outliers. When robust regressions was used, the statistical significance of the differential effect estimates disappear. 


\begin{tabular}{|c|c|c|c|c|c|c|}
\hline & $\begin{array}{c}\text { Kgs of } \\
\text { unshelled } \\
\text { maize }\end{array}$ & $\begin{array}{c}\text { Kgs of } \\
\text { unshelled } \\
\text { maize per } \\
\text { acre }\end{array}$ & $\begin{array}{c}\text { Kgs of } \\
\text { unshelled } \\
\text { maize per } \\
\text { acre (log) }\end{array}$ & $\begin{array}{c}\text { At least } \\
\text { 400kgs } \\
\text { unshelled } \\
\text { maize per } \\
\text { acre } \\
\end{array}$ & $\begin{array}{l}\text { Production } \\
\text { cost of } \\
\text { unshelled } \\
\text { maize per kg } \\
(\mathrm{MKW})\end{array}$ & $\begin{array}{l}\text { Production } \\
\text { cost of } \\
\text { unshelled } \\
\text { maize per kg } \\
\text { (log) }\end{array}$ \\
\hline Poor*treated & 38.8 & 15.7 & -0.031 & 0.017 & -6.12 & -0.035 \\
\hline Coefficient & $(72.8)$ & $(43.1)$ & $(0.14)$ & $(0.16)$ & (11.9) & $(0.043)$ \\
\hline \multicolumn{7}{|l|}{ Wald test (F) } \\
\hline Rich vs. Poor & 0.03 & 0.39 & 2.04 & 0.44 & 0.13 & 1.08 \\
\hline$p$-value & 0.86 & 0.53 & 0.15 & 0.51 & 0.72 & 0.30 \\
\hline
\end{tabular}

\section{By Participant}

\section{Education}

Primary*treated

Coefficient

No primary*treated

Coefficient

Wald test ( $F)$

Primary vs. Non-prim.

$p$-value

$5.63 \quad 128.6$

(169.3)

73.9

(98.7)

(87.0)

3.52

(49.2)

0.12

0.72
1.62

0.20
70.1

(139.7)

$112.0^{*}$

(65.5)

0.08

0.77

\section{3}

(65.0)

42.5

(51.5)

0.00

0.99

\subsection{3}

(0.14)

0.047

(0.12)

0.95

0.33

\subsection{2}

(0.20)

$-0.016$

(0.14)

1.94

0.16
16.8

(10.6)

0.090 *

$(0.053)$

$-11.6$

(9.26)

$-0.043$

(0.036)

2 acre+ vs. less

$p$-value

0.19

(0.14)

$-0.032$

(0.12)

1.47

0.23

\subsection{1}

$-8.50$

(11.7)

$-0.014$

$(0.16)$

4.82

(7.94)

$\begin{array}{lll}(0.17) & (7.94) & (0.039)\end{array}$

\section{By Official Role}

\begin{tabular}{|c|c|c|c|c|c|c|}
\hline $\begin{array}{l}\text { Off. role*treated } \\
\text { Coefficient }\end{array}$ & $\begin{array}{c}96.4 \\
(157.7)\end{array}$ & $\begin{array}{c}67.0 \\
(78.2)\end{array}$ & $\begin{array}{l}0.095 \\
(0.14)\end{array}$ & $\begin{array}{l}0.072 \\
(0.19)\end{array}$ & $\begin{array}{c}11.7 \\
(9.19)\end{array}$ & $\begin{array}{c}0.055 \\
(0.044)\end{array}$ \\
\hline $\begin{array}{l}\text { No off. role*treated } \\
\text { Coefficient }\end{array}$ & $\begin{array}{c}34.6 \\
(96.0)\end{array}$ & $\begin{array}{c}32.1 \\
(49.7)\end{array}$ & $\begin{array}{c}0.12 \\
(0.12)\end{array}$ & $\begin{array}{c}0.13 \\
(0.15)\end{array}$ & $\begin{array}{l}-11.9 \\
(10.2)\end{array}$ & $\begin{array}{l}-0.038 \\
(0.039)\end{array}$ \\
\hline \multicolumn{7}{|l|}{ Wald test (F) } \\
\hline Off. role vs. no off. role & 0.12 & 0.15 & 0.02 & 0.07 & 2.68 & 2.53 \\
\hline$p$-value & 0.73 & 0.70 & 0.90 & 0.79 & 0.10 & 0.11 \\
\hline
\end{tabular}

Standard errors in parentheses

$* \mathrm{p}<0.1, * * \mathrm{p}<0.05, * * * \mathrm{p}<0.01$

Coefficients for covariates used not presented 
TABLE A32. Household Consumption Expenditure-Older versus New Participants, Differential Effects

\begin{tabular}{|c|c|c|c|c|c|c|c|}
\hline & $\begin{array}{c}\text { Adult } \\
\text { equivalent } \\
\text { daily per } \\
\text { person exp. } \\
\text { (PPP) }\end{array}$ & $\begin{array}{c}\text { Log of } \\
\text { adjusted } \\
\text { daily per } \\
\text { person exp. } \\
\text { (PPP) }\end{array}$ & $\begin{array}{c}\text { HH at } \\
\text { least } \$ 1.90 \\
\text { per capita } \\
\text { per day } \\
(P P P) \\
\end{array}$ & $\begin{array}{l}\text { HH below } \\
\$ 1.25 \text { per } \\
\text { capita per } \\
\text { day (PPP) }\end{array}$ & $\begin{array}{l}\text { Daily food } \\
\text { expenditure } \\
\text { per capita } \\
\text { in USD } \\
\text { (PPP) }\end{array}$ & $\begin{array}{l}\text { Proportion } \\
\text { of HH } \\
\text { expenditure } \\
\text { on food }\end{array}$ & Observations \\
\hline $\begin{array}{l}\text { Original OLS } \\
\text { Coefficient }\end{array}$ & $\begin{array}{c}0.25 \\
(0.18)\end{array}$ & $\begin{array}{c}0.084 \\
(0.060)\end{array}$ & $\begin{array}{c}0.12 \\
(0.12)\end{array}$ & $\begin{array}{l}-0.099 \\
(0.13)\end{array}$ & $\begin{array}{c}0.042 \\
(0.083)\end{array}$ & $\begin{array}{l}-0.022 \\
(0.019)\end{array}$ & 620 \\
\hline \multicolumn{8}{|l|}{ By District } \\
\hline $\begin{array}{l}\text { Mzimba*treated } \\
\text { Coefficient }\end{array}$ & $\begin{array}{l}-0.056 \\
(0.33)\end{array}$ & $\begin{array}{l}-0.065 \\
(0.10)\end{array}$ & $\begin{array}{l}-0.031 \\
(0.21)\end{array}$ & $\begin{array}{c}-0.0014 \\
(0.30)\end{array}$ & $\begin{array}{l}-0.15 \\
(0.16)\end{array}$ & $\begin{array}{l}-0.0047 \\
(0.030)\end{array}$ & 620 \\
\hline $\begin{array}{l}\text { Dedza_ } 1 * \text { treated } \\
\text { Coefficient }\end{array}$ & $\begin{array}{l}1.69 * \\
(1.00)\end{array}$ & $\begin{array}{c}0.32 \\
(0.23)\end{array}$ & $\begin{array}{c}0.23 \\
(0.35)\end{array}$ & $\begin{array}{l}-0.35 \\
(0.38)\end{array}$ & $\begin{array}{c}0.48 \\
(0.35)\end{array}$ & $\begin{array}{l}-0.034 \\
(0.061)\end{array}$ & \\
\hline $\begin{array}{l}\text { Dedza_2*treated } \\
\text { Coefficient }\end{array}$ & $\begin{array}{l}-0.091 \\
(0.30)\end{array}$ & $\begin{array}{l}-0.063 \\
(0.12)\end{array}$ & $\begin{array}{c}0.17 \\
(0.24)\end{array}$ & $\begin{array}{l}0.44 * \\
(0.24)\end{array}$ & $\begin{array}{l}0.018 \\
(0.16)\end{array}$ & $\begin{array}{c}0.013 \\
(0.041)\end{array}$ & \\
\hline $\begin{array}{l}\text { Thyolo*treated } \\
\text { Coefficient }\end{array}$ & $\begin{array}{l}0.37 * \\
(0.22)\end{array}$ & $\begin{array}{l}0.27 * * * \\
(0.097)\end{array}$ & $\begin{array}{c}0.20 \\
(0.20)\end{array}$ & $\begin{array}{c}-0.47 * * \\
(0.19)\end{array}$ & $\begin{array}{c}0.13 \\
(0.13)\end{array}$ & $\begin{array}{l}-0.062 * \\
(0.034)\end{array}$ & \\
\hline
\end{tabular}

Wald tests (F)

\begin{tabular}{|c|c|c|c|c|c|c|}
\hline Mzimba vs. Dedza_1 & 2.73 & 2.22 & 0.42 & 0.52 & 2.71 & 0.18 \\
\hline$p$-value & 0.10 & 0.14 & 0.52 & 0.47 & 0.10 & 0.67 \\
\hline Mzimba vs. Dedza_2 & 0.01 & 0.00 & 0.40 & 1.35 & 0.58 & 0.13 \\
\hline$p$-value & 0.94 & 0.99 & 0.53 & 0.24 & 0.44 & 0.72 \\
\hline Mzimba vs. Thyolo & 1.08 & $5.56 * *$ & 0.62 & 1.71 & 1.90 & 1.59 \\
\hline$p$-value & 0.30 & 0.02 & 0.43 & 0.19 & 0.17 & 0.21 \\
\hline Dedza_1 vs. Dedza_2 & $2.90^{*}$ & 2.13 & 0.02 & $3.19 *$ & 1.43 & 0.40 \\
\hline$p$-value & 0.09 & 0.14 & 0.88 & 0.07 & 0.23 & 0.53 \\
\hline Dedza_1 vs. Thyolo & 1.65 & 0.04 & 0.01 & 0.08 & 0.85 & 0.16 \\
\hline$p$-value & 0.20 & 0.85 & 0.93 & 0.78 & 0.36 & 0.69 \\
\hline Dedza_2 vs. Thyolo & 1.48 & $4.65^{* *}$ & 0.01 & $8.90 * * *$ & 0.31 & 2.08 \\
\hline$p$-value & 0.22 & 0.03 & 0.93 & 0.00 & 0.58 & 0.15 \\
\hline
\end{tabular}

\section{By Gender}

$\begin{array}{lcccccc}\begin{array}{l}\text { Female*treated } \\ \text { Coefficient }\end{array} & 0.26 & 0.11 & 0.10 & -0.18 & 0.12 & -0.016 \\ & (0.19) & (0.079) & (0.16) & (0.16) & (0.10) & (0.026) \\ \text { Male*treated } & 0.35 & 0.087 & 0.18 & -0.0083 & -0.047 & -0.042 \\ \text { Coefficient } & (0.29) & (0.088) & (0.18) & (0.21) & (0.14) & (0.026) \\ & & & & & \\ \text { Wald test (F) } & & & & & 0.97 \\ \begin{array}{l}\text { Female vs. Male } \\ p \text {-value }\end{array} & 0.08 & 0.04 & 0.11 & 0.45 & 0.53 & 0.47\end{array}$

\section{By Baseline Wealth Status}

$\begin{array}{lcccccc}\begin{array}{l}\text { Rich*treated } \\ \text { Coefficient }\end{array} & 0.22 & 0.084 & 0.035 & -0.15 & -0.021 & -0.013 \\ & (0.27) & (0.079) & (0.17) & (0.22) & (0.13) & (0.025) \\ \begin{array}{l}\text { Poor*treated } \\ \text { Coefficient }\end{array} & 0.27 & 0.092 & 0.20 & -0.068 & 0.11 & -0.031 \\ & (0.20) & (0.086) & (0.16) & (0.15) & (0.10) & (0.028) \\ \begin{array}{l}\text { Wald test (F) } \\ \text { Rich vs. Poor }\end{array} & & & & & \\ \begin{array}{l}p \text {-value } \\ \text { Nar }\end{array} & 0.02 & 0.00 & 0.49 & 0.09 & 0.57 & 0.24 \\ & 0.88 & 0.95 & 0.48 & 0.76 & 0.45 & 0.63\end{array}$




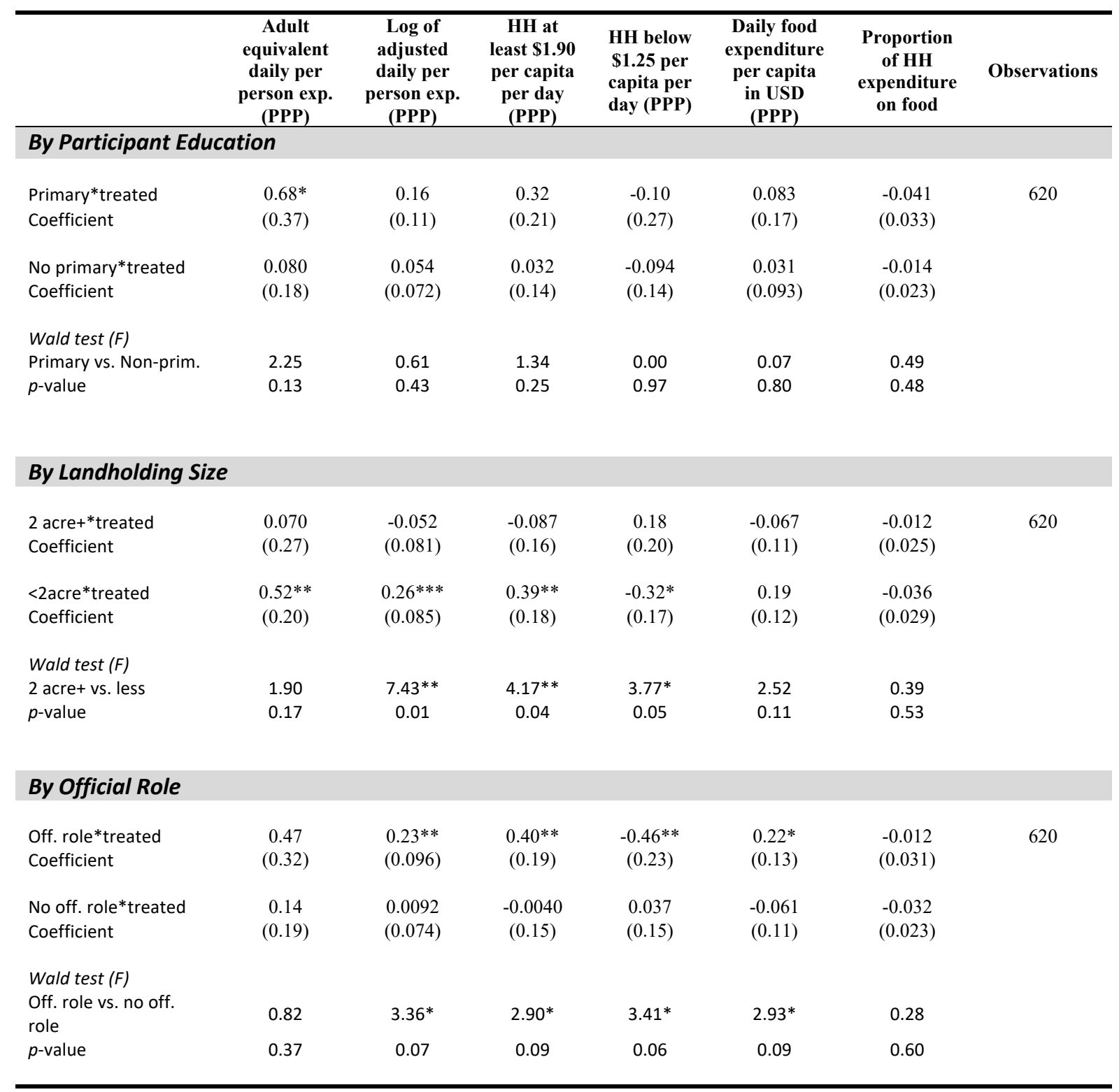

Standard errors in parentheses

$* \mathrm{p}<0.1, * * \mathrm{p}<0.05, * * * \mathrm{p}<0.01$

Coefficients for covariates used not presented

PPP $=$ Purchase Power Parity 
TABLE A33. Household Wealth Asset Measures-Older versus New Participants, Differential Effects

\begin{tabular}{|c|c|c|c|c|c|c|}
\hline & $\begin{array}{c}\text { Raw HH } \\
\text { asset score } \\
2015\end{array}$ & $\begin{array}{l}\text { Dif. raw HH } \\
\text { asset score }\end{array}$ & $\begin{array}{c}2015 \text { asset } \\
\text { index } \\
\text { weighted by } \\
2015 \mathrm{CE} \\
\end{array}$ & $\begin{array}{c}\text { Dif. asset } \\
\text { index } \\
\text { weighted by } \\
2015 \mathrm{CE} \\
\end{array}$ & $\begin{array}{c}\text { PCA } \\
\text { weighted } \\
\text { asset index } \\
2015 \\
\end{array}$ & $\begin{array}{c}\text { Dif. PCA } \\
\text { weighted } \\
\text { asset index }\end{array}$ \\
\hline Original OLS coefficient & $\begin{array}{c}0.29 \\
(0.30)\end{array}$ & $\begin{array}{c}0.20 \\
(0.31)\end{array}$ & $\begin{array}{l}0.0091 \\
(0.028)\end{array}$ & $\begin{array}{c}-0.00068 \\
(0.028)\end{array}$ & $\begin{array}{c}0.010 \\
(0.015)\end{array}$ & $\begin{array}{l}0.0022 \\
(0.024)\end{array}$ \\
\hline Observations & 620 & 620 & 620 & 620 & 625 & 625 \\
\hline \multicolumn{7}{|l|}{ By District } \\
\hline $\begin{array}{l}\text { Mzimba*treated } \\
\text { Coefficient }\end{array}$ & $\begin{array}{c}0.44 \\
(0.60)\end{array}$ & $\begin{array}{c}0.37 \\
(0.62)\end{array}$ & $\begin{array}{l}-0.058 \\
(0.053)\end{array}$ & $\begin{array}{l}-0.084 \\
(0.054)\end{array}$ & $\begin{array}{c}0.035 \\
(0.029)\end{array}$ & $\begin{array}{l}-0.020 \\
(0.047)\end{array}$ \\
\hline $\begin{array}{l}\text { Dedza_1*treated } \\
\text { Coefficient }\end{array}$ & $\begin{array}{c}0.91 \\
(1.13)\end{array}$ & $\begin{array}{c}0.93 \\
(1.10)\end{array}$ & $\begin{array}{c}0.15 \\
(0.10)\end{array}$ & $\begin{array}{c}0.17 \\
(0.10)\end{array}$ & $\begin{array}{c}0.053 \\
(0.049)\end{array}$ & $\begin{array}{c}0.032 \\
(0.064)\end{array}$ \\
\hline $\begin{array}{l}\text { Dedza_ } 2 * \text { treated } \\
\text { Coefficient }\end{array}$ & $\begin{array}{c}0.60 \\
(0.51)\end{array}$ & $\begin{array}{c}0.39 \\
(0.50)\end{array}$ & $\begin{array}{c}0.060 \\
(0.052)\end{array}$ & $\begin{array}{c}0.059 \\
(0.052)\end{array}$ & $\begin{array}{l}0.0017 \\
(0.024)\end{array}$ & $\begin{array}{c}-0.00075 \\
(0.039)\end{array}$ \\
\hline $\begin{array}{l}\text { Thyolo*treated } \\
\text { Coefficient }\end{array}$ & $\begin{array}{l}-0.28 \\
(0.47)\end{array}$ & $\begin{array}{l}-0.34 \\
(0.48)\end{array}$ & $\begin{array}{l}0.0012 \\
(0.044)\end{array}$ & $\begin{array}{l}-0.0038 \\
(0.044)\end{array}$ & $\begin{array}{l}-0.023 \\
(0.023)\end{array}$ & $\begin{array}{c}0.020 \\
(0.042)\end{array}$ \\
\hline
\end{tabular}

Wald tests $(F)$

\begin{tabular}{|c|c|c|c|c|c|c|}
\hline Mzimba vs. Dedza_1 & 0.14 & 0.20 & $3.15^{*}$ & $4.61^{* *}$ & 0.09 & 0.43 \\
\hline$p$-value & 0.71 & 0.66 & 0.08 & 0.03 & 0.76 & 0.51 \\
\hline Mzimba vs. Dedza_2 & 0.04 & 0.00 & 2.55 & $3.69 *$ & 0.78 & 0.11 \\
\hline$p$-value & 0.84 & 0.99 & 0.11 & 0.06 & 0.38 & 0.75 \\
\hline Mzimba vs. Thyolo & 0.89 & 0.83 & 0.74 & 1.32 & 2.41 & 0.41 \\
\hline$p$-value & 0.34 & 0.36 & 0.39 & 0.25 & 0.12 & 0.52 \\
\hline Dedza_1 vs. Dedza_2 & 0.06 & 0.20 & 0.64 & 0.90 & 0.85 & 0.18 \\
\hline$p$-value & 0.80 & 0.66 & 0.42 & 0.34 & 0.36 & 0.67 \\
\hline Dedza_1 vs. Thyolo & 0.95 & 1.13 & 1.78 & 2.37 & 1.94 & 0.02 \\
\hline$p$-value & 0.33 & 0.29 & 0.18 & 0.12 & 0.16 & 0.88 \\
\hline Dedza_2 vs. Thyolo & 1.56 & 1.09 & 0.73 & 0.85 & 0.53 & 0.13 \\
\hline$p$-value & 0.21 & 0.30 & 0.39 & 0.36 & 0.47 & 0.72 \\
\hline \multicolumn{7}{|l|}{ By Gender 25} \\
\hline $\begin{array}{l}\text { Female*treated } \\
\text { Coefficient }\end{array}$ & $\begin{array}{l}-0.13 \\
(0.38)\end{array}$ & $\begin{array}{l}-0.18 \\
(0.40)\end{array}$ & $\begin{array}{l}0.0084 \\
(0.037)\end{array}$ & $\begin{array}{c}0.00024 \\
(0.037)\end{array}$ & $\begin{array}{l}-0.0057 \\
(0.019)\end{array}$ & $\begin{array}{c}-0.064 * * \\
(0.032)\end{array}$ \\
\hline $\begin{array}{l}\text { Male*treated } \\
\text { Coefficient }\end{array}$ & $\begin{array}{l}1.06 * * \\
(0.47)\end{array}$ & $\begin{array}{l}0.84 * \\
(0.47)\end{array}$ & $\begin{array}{c}0.031 \\
(0.041)\end{array}$ & $\begin{array}{c}0.011 \\
(0.043)\end{array}$ & $\begin{array}{l}0.038 * \\
(0.022)\end{array}$ & $\begin{array}{c}0.082 * * \\
(0.035)\end{array}$ \\
\hline \multicolumn{7}{|l|}{ Wald test (F) } \\
\hline Female vs. Male & $3.94 *$ & $2.81^{*}$ & 0.17 & 0.04 & 2.40 & $10.29 * * *$ \\
\hline$p$-value & 0.05 & 0.09 & 0.68 & 0.85 & 0.12 & 0.00 \\
\hline
\end{tabular}

\begin{tabular}{|c|c|c|c|c|c|c|}
\hline \multicolumn{7}{|c|}{ By Baseline Wealth Status } \\
\hline $\begin{array}{l}\text { Rich*treated } \\
\text { Coefficient }\end{array}$ & $\begin{array}{c}0.51 \\
(0.51)\end{array}$ & $\begin{array}{c}0.21 \\
(0.52)\end{array}$ & $\begin{array}{c}-0.0048 \\
(0.045)\end{array}$ & $\begin{array}{l}-0.037 \\
(0.044)\end{array}$ & $\begin{array}{c}0.038 \\
(0.026)\end{array}$ & $\begin{array}{l}-0.015 \\
(0.038)\end{array}$ \\
\hline
\end{tabular}

${ }^{25}$ The difference the gender interaction terms for the differenced PCA measure is considerable, with Year 1 women experienced, on average, less asset gains than Year 3 women and vice-versa for men. However, the application of robust regression reveals that some of this is being driven by outliers. Here, the coefficient is no longer statistically significant for women and that for men is only significant at the $10 \%$ level. The difference between the two coefficients remain, nevertheless, statistically different from zero: $F=4.87 ; p=0.0277$. 


\begin{tabular}{|c|c|c|c|c|c|c|}
\hline & $\begin{array}{c}\text { Raw HH } \\
\text { asset score } \\
\mathbf{2 0 1 5}\end{array}$ & $\begin{array}{l}\text { Dif. raw HH } \\
\text { asset score }\end{array}$ & $\begin{array}{c}2015 \text { asset } \\
\text { index } \\
\text { weighted by } \\
2015 \mathrm{CE}\end{array}$ & $\begin{array}{c}\text { Dif. asset } \\
\text { index } \\
\text { weighted by } \\
2015 \mathrm{CE}\end{array}$ & $\begin{array}{c}\text { PCA } \\
\text { weighted } \\
\text { asset index } \\
2015 \\
\end{array}$ & $\begin{array}{c}\text { Dif. PCA } \\
\text { weighted } \\
\text { asset index }\end{array}$ \\
\hline Poor*treated & 0.093 & 0.18 & 0.027 & 0.036 & -0.011 & 0.013 \\
\hline Coefficient & $(0.32)$ & $(0.33)$ & $(0.034)$ & $(0.035)$ & $(0.013)$ & $(0.029)$ \\
\hline \multicolumn{7}{|l|}{ Wald test (F) } \\
\hline Rich vs. Poor & 0.49 & 0.00 & 0.32 & 1.71 & 3.01 & 0.37 \\
\hline$p$-value & 0.48 & 0.97 & 0.57 & 0.19 & 0.08 & 0.54 \\
\hline \multicolumn{7}{|l|}{ By Participant } \\
\hline \multicolumn{7}{|l|}{ Education } \\
\hline Primary*treated & $1.05 *$ & 0.90 & -0.011 & -0.036 & 0.034 & 0.012 \\
\hline Coefficient & $(0.63)$ & $(0.66)$ & $(0.052)$ & $(0.053)$ & $(0.031)$ & $(0.049)$ \\
\hline No primary*treated & -0.031 & -0.11 & 0.018 & 0.015 & 0.0012 & -0.0021 \\
\hline Coefficient & $(0.35)$ & $(0.34)$ & $(0.033)$ & $(0.033)$ & $(0.016)$ & $(0.027)$ \\
\hline \multicolumn{7}{|l|}{ Wald test $(F)$} \\
\hline Primary vs. Non-prim. & 2.20 & 1.80 & 0.24 & 0.67 & 0.85 & 0.06 \\
\hline$p$-value & 0.14 & 0.18 & 0.63 & 0.41 & 0.36 & 0.81 \\
\hline \multicolumn{7}{|l|}{ By Landholding Size } \\
\hline 2 acre $+*$ treated & $0.79 *$ & 0.60 & 0.0067 & -0.016 & 0.035 & 0.012 \\
\hline Coefficient & $(0.46)$ & $(0.46)$ & $(0.041)$ & $(0.041)$ & $(0.023)$ & $(0.035)$ \\
\hline$<2$ acre ${ }^{*}$ treated & -0.27 & -0.28 & 0.019 & 0.022 & -0.020 & -0.0029 \\
\hline Coefficient & $(0.37)$ & $(0.38)$ & $(0.036)$ & $(0.038)$ & $(0.016)$ & $(0.031)$ \\
\hline \multicolumn{7}{|l|}{ Wald test (F) } \\
\hline 2 acre+ vs. less & $3.38^{*}$ & 2.22 & 0.06 & 0.45 & $4.13^{* *}$ & 0.10 \\
\hline$p$-value & 0.07 & 0.14 & 0.81 & 0.50 & 0.04 & 0.75 \\
\hline \multicolumn{7}{|l|}{ By Official Role } \\
\hline Off. role*treated & $1.13 * *$ & 0.77 & $0.086^{*}$ & 0.055 & $0.058 * *$ & 0.057 \\
\hline Coefficient & $(0.53)$ & $(0.54)$ & $(0.048)$ & $(0.048)$ & $(0.026)$ & $(0.042)$ \\
\hline No off. role*treated & -0.17 & -0.13 & -0.031 & -0.032 & -0.016 & -0.030 \\
\hline Coefficient & $(0.35)$ & $(0.36)$ & $(0.033)$ & $(0.033)$ & $(0.016)$ & $(0.028)$ \\
\hline \multicolumn{7}{|l|}{ Wald test $(F)$} \\
\hline Off. role vs. no off. role & $4.19 * *$ & 2.07 & $4.07^{* *}$ & 2.26 & $5.98 * *$ & $3.16^{*}$ \\
\hline$p$-value & 0.04 & 0.15 & 0.04 & 0.13 & 0.01 & 0.08 \\
\hline
\end{tabular}

Standard errors in parentheses

$* \mathrm{p}<0.1, * * \mathrm{p}<0.05, * * * \mathrm{p}<0.01$

Coefficients for covariates used not presented 
TABLE A34: Food Security \& Other Measures - Older versus New Participants, Differential Effects

\begin{tabular}{|c|c|c|c|c|c|c|c|c|}
\hline & $\begin{array}{c}\text { MDD- } \\
\text { W raw } \\
\text { score } \\
(/ 10)\end{array}$ & $\begin{array}{c}\text { MDD- } \\
W \\
\text { Binary } \\
(>4 \\
\text { points }) \\
\end{array}$ & $\begin{array}{c}\text { Reported } \\
\text { food } \\
\text { insecure } \\
\text { months }\end{array}$ & $\begin{array}{c}\text { HFIAS } \\
\text { (previous } \\
\mathbf{4} \text { weeks) }\end{array}$ & $\begin{array}{l}\text { Decrease } \\
\text { in time } \\
\text { collecting } \\
\text { fuel wood }\end{array}$ & $\begin{array}{c}\text { Increase } \\
\text { in time } \\
\text { collecting } \\
\text { fuel } \\
\text { wood } \\
\end{array}$ & $\begin{array}{c}\text { Observed } \\
\text { soil } \\
\text { erosion }\end{array}$ & $\begin{array}{c}\text { Perceived } \\
\text { soil } \\
\text { fertility } \\
\text { good }\end{array}$ \\
\hline Original OLS coefficient & $\begin{array}{l}0.080 \\
(0.11)\end{array}$ & $\begin{array}{l}0.024 \\
(0.14)\end{array}$ & $\begin{array}{l}0.020 \\
(0.22)\end{array}$ & $\begin{array}{c}0.19 \\
(0.18)\end{array}$ & $\begin{array}{c}0.34 * * \\
(0.14)\end{array}$ & $\begin{array}{l}-0.15 \\
(0.11)\end{array}$ & $\begin{array}{r}-0.030 \\
(0.12)\end{array}$ & $\begin{array}{c}0.25 * * \\
(0.12)\end{array}$ \\
\hline Observations & 617 & 609 & 620 & 620 & 612 & 620 & 620 & 620 \\
\hline \multicolumn{9}{|l|}{ By District } \\
\hline $\begin{array}{l}\text { Mzimba*treated } \\
\text { Coefficient }\end{array}$ & $\begin{array}{c}0.22 \\
(0.20)\end{array}$ & $\begin{array}{c}0.12 \\
(0.21)\end{array}$ & $\begin{array}{r}-0.054 \\
(0.31)\end{array}$ & $\begin{array}{r}-0.010 \\
(0.32)\end{array}$ & $\begin{array}{c}0.20 \\
(0.26)\end{array}$ & $\begin{array}{l}0.090 \\
(0.19)\end{array}$ & $\begin{array}{c}0.34 \\
(0.26)\end{array}$ & $\begin{array}{l}0.50 * * \\
(0.21)\end{array}$ \\
\hline $\begin{array}{l}\text { Dedza_ } 1 * \text { treated } \\
\text { Coefficient }\end{array}$ & $\begin{array}{c}0.28 \\
(0.32)\end{array}$ & $\begin{array}{c}0.29 \\
(0.48)\end{array}$ & $\begin{array}{r}-1.44 * \\
(0.74)\end{array}$ & $\begin{array}{l}-0.16 \\
(0.55)\end{array}$ & $\begin{array}{l}-0.61 \\
(0.45)\end{array}$ & $\begin{array}{r}-0.044 \\
(0.36)\end{array}$ & $\begin{array}{c}-1.01 * * \\
(0.52)\end{array}$ & $\begin{array}{c}0.16 \\
(0.35)\end{array}$ \\
\hline $\begin{array}{l}\text { Dedza_2*treated } \\
\text { Coefficient }\end{array}$ & $\begin{array}{l}-0.18 \\
(0.23)\end{array}$ & $\begin{array}{l}-0.033 \\
(0.27)\end{array}$ & $\begin{array}{c}0.56 \\
(0.52)\end{array}$ & $\begin{array}{l}0.67 * \\
(0.37)\end{array}$ & $\begin{array}{c}0.66^{* *} \\
(0.33)\end{array}$ & $\begin{array}{l}-0.068 \\
(0.23)\end{array}$ & $\begin{array}{l}-0.081 \\
(0.23)\end{array}$ & $\begin{array}{l}-0.066 \\
(0.23)\end{array}$ \\
\hline $\begin{array}{l}\text { Thyolo*treated } \\
\text { Coefficient }\end{array}$ & $\begin{array}{l}0.058 \\
(0.19)\end{array}$ & $\begin{array}{l}-0.13 \\
(0.25)\end{array}$ & $\begin{array}{c}0.15 \\
(0.38)\end{array}$ & $\begin{array}{c}0.15 \\
(0.32)\end{array}$ & $\begin{array}{l}0.54 * * \\
(0.22)\end{array}$ & $\begin{array}{c}-0.47 * * \\
(0.20)\end{array}$ & $\begin{array}{l}-0.056 \\
(0.20)\end{array}$ & $\begin{array}{c}0.28 \\
(0.20)\end{array}$ \\
\hline
\end{tabular}

Wald tests (F)

\begin{tabular}{|c|c|c|c|c|c|c|c|c|}
\hline Mzimba vs. Dedza_1 & 0.03 & 0.10 & $2.97^{*}$ & 0.05 & 2.41 & 0.11 & $5.46 * *$ & 0.67 \\
\hline$p$-value & 0.87 & 0.76 & 0.09 & 0.82 & 0.12 & 0.74 & 0.02 & 0.41 \\
\hline Mzimba vs. Dedza_2 & 1.72 & 0.20 & 1.02 & 1.90 & 1.19 & 0.28 & 1.49 & $3.29 *$ \\
\hline$p$-value & 0.19 & 0.66 & 0.31 & 0.17 & 0.27 & 0.60 & 0.22 & 0.07 \\
\hline Mzimba vs. Thyolo & 0.33 & 0.55 & 0.17 & 0.13 & 0.93 & $4.10 * *$ & 1.45 & 0.54 \\
\hline$p$-value & 0.57 & 0.46 & 0.68 & 0.72 & 0.33 & 0.04 & 0.23 & 0.46 \\
\hline Dedza_1 vs. Dedza_2 & 1.43 & 0.33 & $4.83^{* *}$ & 1.59 & $5.23 * *$ & 0.00 & 2.76 & 0.30 \\
\hline$p$-value & 0.23 & 0.56 & 0.03 & 0.21 & 0.02 & 0.95 & 0.10 & 0.58 \\
\hline Dedza_1 vs. Thyolo & 0.37 & 0.57 & $3.78^{*}$ & 0.26 & $5.24 * *$ & 1.10 & $2.98 *$ & 0.09 \\
\hline$p$-value & 0.54 & 0.45 & 0.05 & 0.61 & 0.02 & 0.29 & 0.08 & 0.76 \\
\hline Dedza_2 vs. Thyolo & 0.66 & 0.06 & 0.41 & 1.12 & 0.10 & 1.76 & 0.01 & 1.38 \\
\hline$p$-value & 0.42 & 0.80 & 0.52 & 0.29 & 0.75 & 0.18 & 0.93 & 0.24 \\
\hline \multicolumn{9}{|l|}{ By Gender } \\
\hline $\begin{array}{l}\text { Female*treated } \\
\text { Coefficient }\end{array}$ & $\begin{array}{l}0.057 \\
(0.14)\end{array}$ & $\begin{array}{c}-0.0077 \\
(0.19)\end{array}$ & $\begin{array}{l}-0.011 \\
(0.32)\end{array}$ & $\begin{array}{c}0.27 \\
(0.27)\end{array}$ & $\begin{array}{c}0.37 * * \\
(0.17)\end{array}$ & $\begin{array}{l}-0.26^{*} \\
(0.15)\end{array}$ & $\begin{array}{l}-0.084 \\
(0.16)\end{array}$ & $\begin{array}{l}0.066 \\
(0.13)\end{array}$ \\
\hline $\begin{array}{l}\text { Male*treated } \\
\text { Coefficient }\end{array}$ & $\begin{array}{c}0.18 \\
(0.17)\end{array}$ & $\begin{array}{c}0.11 \\
(0.19)\end{array}$ & $\begin{array}{l}-0.045 \\
(0.30)\end{array}$ & $\begin{array}{c}-0.0039 \\
(0.24)\end{array}$ & $\begin{array}{c}0.26 \\
(0.22)\end{array}$ & $\begin{array}{l}-0.019 \\
(0.17)\end{array}$ & $\begin{array}{l}0.023 \\
(0.19)\end{array}$ & $\begin{array}{c}0.52 * * * \\
(0.14)\end{array}$ \\
\hline \multicolumn{9}{|l|}{ Wald test $(F)$} \\
\hline Female vs. Male & 0.30 & 0.21 & 0.01 & 0.59 & 0.14 & 1.15 & 0.19 & 1.64 \\
\hline$p$-value & 0.58 & 0.64 & 0.94 & 0.44 & 0.71 & 0.28 & 0.67 & 0.20 \\
\hline \multicolumn{9}{|c|}{ By Baseline Wealth Status } \\
\hline $\begin{array}{l}\text { Rich*treated } \\
\text { Coefficient }\end{array}$ & $\begin{array}{c}0.31 * * \\
(0.16)\end{array}$ & $\begin{array}{c}0.41 * * \\
(0.19)\end{array}$ & $\begin{array}{l}-0.51 * \\
(0.29)\end{array}$ & $\begin{array}{l}-0.26 \\
(0.23)\end{array}$ & $\begin{array}{c}0.12 \\
(0.19)\end{array}$ & $\begin{array}{l}0.15 \\
(0.16)\end{array}$ & $\begin{array}{l}-0.083 \\
(0.18)\end{array}$ & $\begin{array}{c}0.39 * * \\
(0.17)\end{array}$ \\
\hline $\begin{array}{l}\text { Poor*treated } \\
\text { Coefficient }\end{array}$ & $\begin{array}{l}-0.17 \\
(0.15)\end{array}$ & $\begin{array}{c}-0.40 * * \\
(0.19)\end{array}$ & $\begin{array}{c}0.47 \\
(0.34)\end{array}$ & $\begin{array}{l}0.59 * * \\
(0.28)\end{array}$ & $\begin{array}{c}0.57 * * * \\
(0.19)\end{array}$ & $\begin{array}{c}-0.44 * * * \\
(0.16)\end{array}$ & $\begin{array}{l}0.021 \\
(0.16)\end{array}$ & $\begin{array}{c}0.11 \\
(0.16)\end{array}$ \\
\hline \multicolumn{9}{|l|}{ Wald test (F) } \\
\hline Rich vs. Poor & $4.89 * *$ & $9.56^{* * *}$ & $4.53^{* *}$ & $5.60 * *$ & $2.97^{*}$ & $7.15 * *$ & 0.19 & 1.59 \\
\hline$p$-value & 0.03 & 0.00 & 0.03 & 0.02 & 0.08 & 0.01 & 0.66 & 0.21 \\
\hline
\end{tabular}




\begin{tabular}{|c|c|c|c|c|c|c|c|c|}
\hline & $\begin{array}{l}\text { MDD- } \\
\text { W raw } \\
\text { score } \\
(/ \mathbf{1 0})\end{array}$ & $\begin{array}{c}\text { MDD- } \\
W \\
\text { Binary } \\
\text { (>4 } \\
\text { points) }\end{array}$ & $\begin{array}{l}\text { Reported } \\
\text { food } \\
\text { insecure } \\
\text { months }\end{array}$ & $\begin{array}{c}\text { HFIAS } \\
\text { (previous } \\
\text { 4 weeks) }\end{array}$ & $\begin{array}{l}\text { Decrease } \\
\text { in time } \\
\text { collecting } \\
\text { fuel wood }\end{array}$ & $\begin{array}{c}\text { Increase } \\
\text { in time } \\
\text { collecting } \\
\text { fuel } \\
\text { wood } \\
\end{array}$ & $\begin{array}{c}\text { Observed } \\
\text { soil } \\
\text { erosion }\end{array}$ & $\begin{array}{c}\text { Perceived } \\
\text { soil } \\
\text { fertility } \\
\text { good }\end{array}$ \\
\hline \multicolumn{9}{|l|}{ By Participant } \\
\hline \multicolumn{9}{|l|}{ Education } \\
\hline Primary*treated & 0.27 & 0.23 & 0.057 & -0.28 & -0.023 & $0.55^{* * *}$ & 0.23 & $0.44 * *$ \\
\hline Coefficient & $(0.21)$ & $(0.23)$ & $(0.40)$ & $(0.34)$ & $(0.25)$ & $(0.20)$ & $(0.24)$ & $(0.21)$ \\
\hline No primary*treated & -0.0047 & -0.086 & 0.00029 & $0.39 *$ & $0.48 * * *$ & $-0.47 * * *$ & -0.14 & 0.17 \\
\hline Coefficient & $(0.13)$ & $(0.16)$ & $(0.27)$ & $(0.23)$ & $(0.16)$ & $(0.14)$ & $(0.14)$ & $(0.14)$ \\
\hline \multicolumn{9}{|l|}{ Wald test $(F)$} \\
\hline Primary vs. Non-prim. & 1.23 & 1.27 & 0.01 & 2.53 & $2.82 *$ & $17.30 * * *$ & 1.78 & 1.14 \\
\hline$p$-value & 0.27 & 0.26 & 0.91 & 0.11 & 0.09 & 0.00 & 0.18 & 0.29 \\
\hline \multicolumn{9}{|l|}{ By Landholding Size } \\
\hline $\begin{array}{l}2 \text { acre }+* \text { treated } \\
\text { Coefficient }\end{array}$ & $\begin{array}{c}0.12 \\
(0.15)\end{array}$ & $\begin{array}{c}0.21 \\
(0.18)\end{array}$ & $\begin{array}{c}0.12 \\
(0.28)\end{array}$ & $\begin{array}{l}0.028 \\
(0.23)\end{array}$ & $\begin{array}{c}0.25 \\
(0.18)\end{array}$ & $\begin{array}{l}0.059 \\
(0.15)\end{array}$ & $\begin{array}{c}-0.0094 \\
(0.17)\end{array}$ & $\begin{array}{c}0.31 * * \\
(0.14)\end{array}$ \\
\hline $\begin{array}{l}<2 \text { acre*treated } \\
\text { Coefficient }\end{array}$ & $\begin{array}{l}0.020 \\
(0.16)\end{array}$ & $\begin{array}{l}-0.26 \\
(0.21)\end{array}$ & $\begin{array}{l}-0.13 \\
(0.36)\end{array}$ & $\begin{array}{c}0.34 \\
(0.30)\end{array}$ & $\begin{array}{c}0.46^{* *} \\
(0.20)\end{array}$ & $\begin{array}{c}-0.46^{* * *} \\
(0.17)\end{array}$ & $\begin{array}{l}-0.053 \\
(0.17)\end{array}$ & $\begin{array}{l}0.25^{*} \\
(0.14)\end{array}$ \\
\hline \multicolumn{9}{|l|}{ Wald test $(F)$} \\
\hline 2 acre+ vs. less & 0.20 & $3.01^{*}$ & 0.30 & 0.66 & 0.66 & $5.36 * *$ & 0.03 & 0.98 \\
\hline$p$-value & 0.66 & 0.08 & 0.58 & 0.42 & 0.42 & 0.02 & 0.86 & 0.32 \\
\hline \multicolumn{9}{|l|}{ By Official Role } \\
\hline $\begin{array}{l}\text { Off. role*treated } \\
\text { Coefficient }\end{array}$ & $\begin{array}{l}-0.11 \\
(0.20)\end{array}$ & $\begin{array}{l}-0.14 \\
(0.20)\end{array}$ & $\begin{array}{l}-0.078 \\
(0.33)\end{array}$ & $\begin{array}{l}0.026 \\
(0.25)\end{array}$ & $\begin{array}{c}0.49 * * \\
(0.22)\end{array}$ & $\begin{array}{l}-0.13 \\
(0.18)\end{array}$ & $\begin{array}{l}-0.12 \\
(0.20)\end{array}$ & $\begin{array}{c}0.54 * * * \\
(0.18)\end{array}$ \\
\hline $\begin{array}{l}\text { No off. role*treated } \\
\text { Coefficient }\end{array}$ & $\begin{array}{l}0.21^{*} \\
(0.12)\end{array}$ & $\begin{array}{c}0.19 \\
(0.18)\end{array}$ & $\begin{array}{l}0.062 \\
(0.29)\end{array}$ & $\begin{array}{c}0.26 \\
(0.25)\end{array}$ & $\begin{array}{c}0.25 \\
(0.17)\end{array}$ & $\begin{array}{l}-0.16 \\
(0.14)\end{array}$ & $\begin{array}{l}0.0047 \\
(0.15)\end{array}$ & $\begin{array}{l}0.084 \\
(0.14)\end{array}$ \\
\hline \multicolumn{9}{|l|}{ Wald test (F) } \\
\hline Off. role vs. no off. role & 1.83 & 1.51 & 0.10 & 0.45 & 0.74 & 0.02 & 0.24 & $3.87 * *$ \\
\hline$p$-value & 0.18 & 0.22 & 0.76 & 0.50 & 0.39 & 0.88 & 0.62 & 0.049 \\
\hline
\end{tabular}

Standard errors in parentheses

* $\mathrm{p}<0.1,{ }^{* *} \mathrm{p}<0.05, * * * \mathrm{p}<0.01$

Coefficients for covariates used not presented 
Annex 4: List of Binary Household Assets and Other Wealth Indicators

\begin{tabular}{|c|c|c|c|}
\hline No. & Wealth asset/indicator & No. & Wealth asset/indicator \\
\hline 1 & One oxen & 44 & charcoal stove \\
\hline 2 & Two oxen & 45 & electric or gas stove \\
\hline 3 & More than two oxen & 46 & modern cooking pots (bought at the shop) \\
\hline 4 & One or two local cows & 47 & fan \\
\hline 5 & More than two local cows & 48 & charcoal iron \\
\hline 6 & One dairy cows & 49 & electric iron \\
\hline 7 & Two dairy cows & 50 & wrist watch \\
\hline 8 & More than two dairy cows & 51 & clock on the wall \\
\hline 9 & One to three Sheep and/or Goat & 52 & kerosene lamp \\
\hline 10 & More than three Sheep and/or Goats & 53 & electric lamp \\
\hline 11 & One to five poultry birds & 54 & torch \\
\hline 12 & Five to ten poultry birds & 55 & mirror on the wall \\
\hline 13 & More than ten poultry birds & 56 & floor mat/rug \\
\hline 14 & One or two donkeys & 57 & sewing machine \\
\hline 15 & More than two donkeys & 58 & one simple mobile phone \\
\hline 16 & One to three Pigs & 59 & more than one simple mobile phone \\
\hline 17 & $\begin{array}{l}\text { More than three Pigs (or at least one large } \\
\text { improved pig) }\end{array}$ & 60 & one or more smart phone \\
\hline 18 & ox plough & 61 & radio \\
\hline 19 & ox/horse/donkey cart & 62 & tape or CD player \\
\hline 20 & hoe & 63 & television \\
\hline 21 & sickle & 64 & TV cabinet \\
\hline 22 & shovel & 65 & satellite dish \\
\hline 23 & axe & 66 & DVD player \\
\hline 24 & pic axe & 67 & solar panel for house \\
\hline 25 & rake & 68 & hot water flask \\
\hline 26 & watering can & 69 & glass window \\
\hline 27 & protected shallow well & 70 & wooden front door \\
\hline 28 & fish pond & 71 & metal front door \\
\hline 29 & wood lot & 72 & suitcase \\
\hline 30 & tractor & 73 & generator \\
\hline 31 & wheel barrow & 74 & bicycle \\
\hline 32 & treadle pump & 75 & motorcycle \\
\hline 33 & motorized water pump & 76 & car/truck \\
\hline 34 & carpentry tools (e.g. hammer, saw) & 77 & small shop/grocery \\
\hline 35 & sprayer & 78 & $\begin{array}{l}\text { building not for personal dwelling like store, } \\
\text { warehouse, video shop }\end{array}$ \\
\hline 36 & maize mill & 79 & coffee/tea room \\
\hline 37 & more than one chair & 80 & water tank \\
\hline 38 & sofa/couch & 81 & Electricity \\
\hline 39 & dining table & 82 & pit latrine with slab but no bricks/iron sheet \\
\hline 40 & coffee table & 83 & $\begin{array}{l}\text { pit latrine with slab with bricks and iron } \\
\text { sheet }\end{array}$ \\
\hline 41 & bed & 84 & cemented floor \\
\hline 42 & mattress & 85 & cemented wall \\
\hline 43 & fridge/freezer & 86 & iron sheet \\
\hline
\end{tabular}




\section{Working Paper Series}

240. The national agroforestry policy of India: experiential learning in development and delivery phases. http://dx.doi.org/10.5716/WP16143.PDF

241. Agroforestry and forestry in Sulawesi series: Livelihood strategies and land-use system dynamics in Gorontalo. http://dx.doi.org/10.5716/WP16157.PDF

242. Seri Agroforestri dan Kehutanan di Sulawesi: Strategi mata pencaharian dan dinamika system penggunaan lahan di Gorontalo. http://dx.doi.org/10.5716/WP16158.PDF

243. Ruang, Gender dan Kualitas Hidup Manusia: Sebuah studi Gender pada komunitas perantau dan pengelola kebun di Jawa Barat. http://dx.doi.org/10.5716/WP16159.PDF

244. Gendered knowledge and perception in managing grassland areas in East Sumba, Indonesia. http://dx.doi.org/10.5716/WP16160.PDF

245. Pengetahuan dan persepsi masyarakat pengelola padang aavana, Sebuah Kajian Gender di Sumba Timur. http://dx.doi.org/10.5716/WP16161.PDF

246. Dinamika Pengambilan Keputusan pada komunitas perantau dan pengelola kebun di Jawa Barat. http://dx.doi.org/10.5716/WP16162.PDF

247. Gaharu (eaglewood) domestication: biotechnology, markets and agroforestry options. http://dx.doi.org/10.5716/WP16163.PDF

248. Marine habitats of the Lamu-Kiunga coast: an assessment of biodiversity value, threats and opportunities. http://dx.doi.org/10.5716/WP16167.PDF

249. Assessment of the biodiversity in terrestrial landscapes of the Witu protected area and surroundings, Lamu County, Kenya. http://dx.doi.org/10.5716/WP16172.PDF

250. An ecosystem services perspective on benefits that people derive from biodiversity of Coastal forests in Lamu County, Kenya http://dx.doi.org/10.5716/WP16173.PDF

251. Assessment of the biodiversity in terrestrial and marine landscapes of the proposed Laga Badana National Park and surrounding areas, Jubaland, Somalia.

http://dx.doi.org/10.5716/WP16174.PDF

2017

252. Preferensi Petani terhadap Topik Penyuluhan dan Penyebaran Informasi Agroforestri di Indonesia http://dx.doi.org/10.5716/WP16181.PDF

253. Seri Agroforestri dan Kehutanan di Sulawesi: Keanekaragaman hayati jenis pohon pada hutan rakyat agroforestri di DAS Balangtieng, Sulawesi Selatan http://dx.doi.org/10.5716/WP16182.PDF

254. Potensi dan Tantangan dalam Pengembangan Skema Ko-Investasi Jasa Lingkungan di Kabupaten Buol, Indonesia. http://dx.doi.org/10.5716/WP17008.PDF

255. Keragaman Jenis Pohon dan Pemanfaatannya oleh Masyarakat di Kabupaten Buol, Indonesia. http://dx.doi.org/10.5716/WP17009.PDF 
256. Kerentanan dan preferensi sistem pertanian petani di Kabupaten Buol, Indonesia http://dx.doi.org/10.5716/WP17010.PDF

257. Dinamika Perubahan Penggunaan/Tutupan Lahan Serta Cadangan Karbon di Kabupaten Buol, Indonesia. http://dx.doi.org/10.5716/WP17011.PDF

258. The effectiveness of the volunteer farmer trainer approach vis-à-vis other information sources in dissemination of livestock feed technologies in Uganda. http://dx.doi.org/10.5716/WP17104.PDF

259. Agroforestry and forestry in Sulawesi series: Impact of agricultural-extension booklets on community livelihoods in South and Southeast Sulawesi. http://dx.doi.org/10.5716/WP17125.PDF

260. Petani Menjadi Penyuluh, Mungkinkah? Sebuah Pendekatan Penyuluhan dari Petani ke Petani di Kabupaten Sumb Timur. http://dx.doi.org/10.5716/WP17145.PDF

261. Dampak Perubahan Tutupan Lahan terhadap Kondisi Hidrologi di Das Buol, Kabupaten Buol, Sulawesi Tengah: Simulasi dengan Model Genriver http://dx.doi.org/10.5716/WP17146.PDF

262. Analisis Tapak Mata Air Umbulan, Pasuruan, Jawa Timur. Kajian elemen biofisik dan persepsi masyarakat. http://dx.doi.org/10.5716/WP17147.PDF

263. Planned comparisons demystified. http://dx.doi.org/10.5716/WP17354.PDF

264. Soil health decision support for NERC digital soil platforms: A survey report http://dx.doi.org/10.5716/WP17355.PDF

265. Seri Pembangunan Ekonomi Pedesaan Indonesia: Menanam di bukit gundul: Pengetahuan masyarakat lokal dalam upaya restorasi lahan di Sumba

Timur. http://dx.doi.org/10.5716/WP17356.PDF

266. Tree diversity and carbon stock in three districts of Kutai Timur, Pasir and Berau, East Kalimantan http://dx.doi.org/10.5716/WP17357.PDF

267. Tree Diversity and Carbon Stock in Various Land Use Systems of Banyuasin and Musi Banyuasin Districts, South Sumatera http://dx.doi.org/10.5716/WP17358.PDF

268. Tree diversity and carbon stock in various land cover systems of Jayapura, Jayawijaya and Merauke Districts, Papua Province http://dx.doi.org/10.5716/WP17359.PDF

269. Modelling tree production based on farmers' knowledge: case for kapok (Ceiba pentandra) and candlenut (Aleurites mollucana) under various agroforestry scenarios.

http://dx.doi.org/10.5716/WP17361.PDF

270. The Impact of Land Cover and Climate Change on Present and Future Watershed Condition. Study case: Tugasan, Alanib and Kulasihan Sub-watershed of Manupali Watershed, Lantapan, Bukidnon, Philippines. http://dx.doi.org/10.5716/WP17362.PDF

271. Tree Diversity and Above-ground Carbon Stock estimation in Various Land use Systems in Banjarnegara, Banyumas and Purbalingga, Central Java.

http://dx.doi.org/10.5716/WP17363.PDF

272. Agroforestry and Forestry in Sulawesi series: Landscape Management Strategies in Sulawesi: Review of Intervention Options. http://dx.doi.org/10.5716/WP17364.PDF 
273. Household Food-Security and Nutritional Status of Women and Children in Buol Regency, Central Sulawesi, Indonesia. http://dx.doi.org/10.5716/WP17365.PDF

274. Palm oil expansion in tropical forest margins or sustainability of production? Focal issues of regulations and private standards. http://dx.doi.org/10.5716/WP17366.PDF

\section{$\underline{2018}$}

275. Decision analysis methods guide: Agricultural policy for nutrition http://dx.doi.org/10.5716/WP18001.PDF

276. Supporting human nutrition in Africa through the integration of new and orphan crops into food systems: Placing the work of the African Orphan Crops Consortium in context. http://dx.doi.org/10.5716/WP18003.PDF

277. Seri Pembangunan Ekonomi Pedesaan Indonesia. Pilihan Manajemen Budidaya Kacang Tanah sebagai Upaya untuk Memperbaiki Penghidupan Masyarakat Haharu.

\section{http://dx.doi.org/10.5716/WP18004.PDF}

278. Estudio de línea de base CCAFS a nivel de hogar en Nicaragua y Costa Rica Fase de diagnóstico del estudio: "Contribución de la diversidad arbórea a los medios de vida para la adaptación y la mitigación al cambio climático http://dx.doi.org/10.5716/WP18005.PDF

279. Understanding tree cover transition, drivers and stakeholder perspectives for effective landscape governance. A case study in Na Nhan commune, Dien Bien province, Vietnam. http://dx.doi.org/10.5716/WP18006.PDF

280. El Sistema "Quesungual": Agroforestería y manejo de suelos para la producción de maíz y frijol en laderas. http://dx.doi.org/10.5716/WP18007.PDF

281: Probabilistic Decision Modelling to Determine Impacts on Natural Resource Management and Livelihood Resilience in Marsabit County, Kenya. http://dx.doi.org/10.5716/WP18008.PDF

282. Shifting discourse, shifting power: how is climate change mitigation and justice negotiated in Indonesia? http://dx.doi.org/10.5716/WP18009.PDF

283. Result of Land Use Planning and Land Administration (LULA) Implementation in South Sumatra, East Kalimantan, Central Java and Papua http://dx.doi.org/10.5716/WP18010.PDF

284. Farmers' preferences for training topics and dissemination of agroforestry information in Indonesia. http://dx.doi.org/10.5716/WP18015.PDF

285. CSA-Diagnostic (CSA-Dx): A primer for investigating the 'climate-smartness' of ag technologies http://dx.doi.org/10.5716/WP18020.PDF

286. An analysis of the vulnerability of poor communities in Yunnan Province, China

http://dx.doi.org/10.5716/WP18021.PDF

287. Gendered space and quality of life: gender study of out-migration and smallholding agroforestry communities in West Java Province, Indonesia. http://dx.doi.org/10.5716/WP18024.PDF 
288: Evaluation of UTZ certification coffee businesses in Guatemala, Honduras and Nicaragua. http://dx.doi.org/10.5716/WP18028.PDF

289. Agroforestry species of Peru: annotated list and contribution to prioritization for genetic conservation. http://dx.doi.org/10.5716/WP18029.PDF

290. Indonesia Rural Economic Development Series.Growing plants on a barren hill: local knowledge as part of land restoration in Sumba Timur, Indonesia. http://dx.doi.org/10.5716/WP18030.PDF

291. Assessing the Downstream Socioeconomic Impacts of Agroforestry in Kenya http://dx.doi.org/10.5716/WP18033.PDF

$\underline{2019}$

292: Los árboles fuera del bosque en la NAMA forestal de Colombia. Elementos conceptuales para su contabilización. http://dx.doi.org/10.5716/WP19002.PDF

293: Gender and Adaptation: An Analysis of Poverty and Vulnerability in Yunnan, China. DOI:

http://dx.doi.org/10.5716/WP19004.PDF

294: Tree Cover on Agricultural Land in the Asia Pacific Region

DOI: http://dx.doi.org/10.5716/WP19005.PDF

295: What do we really know about the impacts of improved grain legumes and dryland cereals? A critical review of 18 impact studies DOI: http://dx.doi.org/10.5716/WP19006.PDF

296: Breeders' views on the production of new and orphan crops in Africa: a survey of constraints and opportunities DOI: http://dx.doi.org/10.5716/WP19007.PDF

297: Biomass Resources in Rhino Camp and Imvepi Refugee Settlements and the Buffer Zone around these Settlements in West Nile, Uganda DOI: http://dx.doi.org/10.5716/WP19031.PDF

298: Option for restocking woody biomass in refugee-hosting areas: Perspectives from communities in Rhino Camp and Imvepi Settlements, Uganda DOI: http://dx.doi.org/10.5716/WP19032.PDF

299: Restoring ecosystems in refugee settlements using tree-based systems: The case of Rhino Camp and Imvepi Settlements in Uganda. DOI: http://dx.doi.org/10.5716/WP19033.PDF 
World Agroforestry (ICRAF) is a centre of scientific and development excellence that harnesses the benefits of trees for people and the environment. Leveraging the world's largest repository of agroforestry science and information, we develop knowledge practices, from farmers' fields to the global sphere, to ensure food security and environmental sustainability.

ICRAF is the only institution that does globally significant agroforestry research in and for all of the developing tropics. Knowledge produced by ICRAF enables governments, development agencies and farmers to utilize the power of trees to make farming and livelihoods more environmentally, socially and economically sustainable at multiple scales.

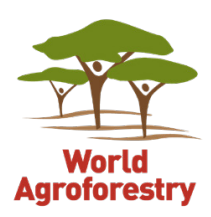

United Nations Avenue, Gigiri • PO Box 30677 • Nairobi, $00100 \cdot$ Kenya Telephone: +254207224000 or via USA +1 6508336645 Fax: +254207224001 or via USA +1 6508336646 Email: worldagroforestry@cgiar.org•www.worldagroforestry.org 